LÍGIA DIAS DE ARAUJO

\title{
ECHO CHARACTER AND SEDIMENTARY PROCESSES ON THE CONTINENTAL SHELF OF THE SÃO PAULO STATE
}

Master's thesis presented to the Oceanographic Institute of the University of São Paulo as part of the fulfillment of the requirements for obtaining the title of Master of Science, with emphasis in Geological Oceanography

Advisor: Michel Michaelovitch de Mahiques

Co-advisor: Francisco José Lobo Sánchez

\section{SÃO PAULO}




\author{
UNIVERSITY OF SÃO PAULO \\ OCEANOGRAPHIC INSTITUTE
}

\title{
ECHO CHARACTER AND SEDIMENTARY PROCESSES ON THE CONTINENTAL SHELF OF THE SÃO PAULO STATE
}

\author{
LÍGIA DIAS DE ARAUJO
}

Thesis presented to the Oceanographic Institute of the University of São Paulo as part of the requirements for obtaining the title of Master of Science in Oceanography, with emphasis in Geological Oceanography.

Corrected Version 
“... sonhos não envelhecem”

(Márcio Borges) 


\section{Table of Contents}

Acknowledgment

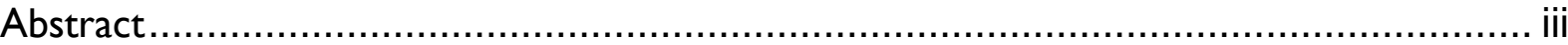

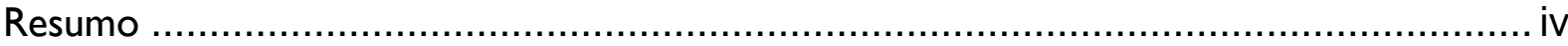

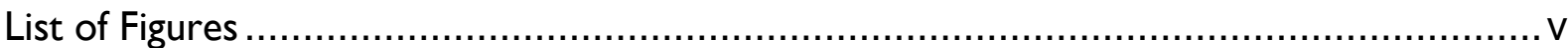

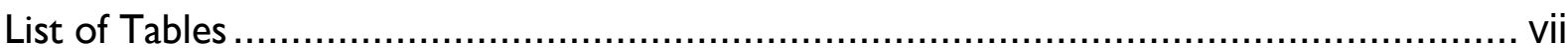

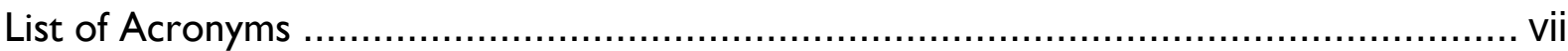

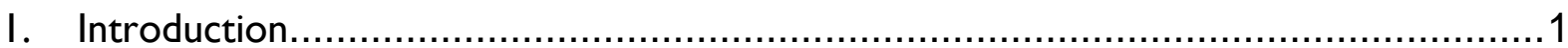

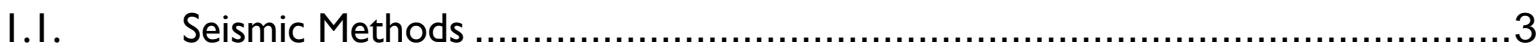

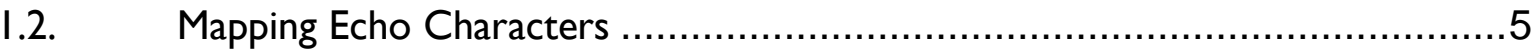

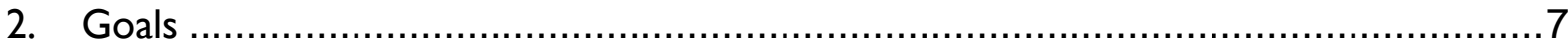

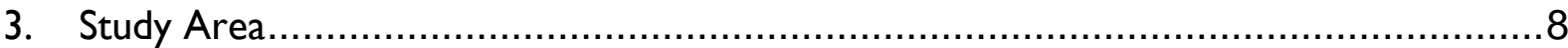

3.I. Geological Evolution and Sea-Level Changes ......................................

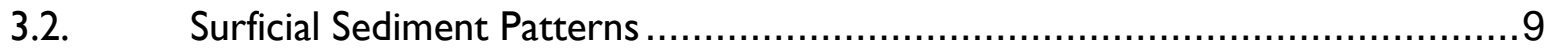

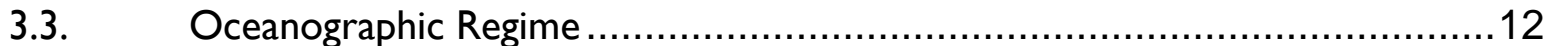

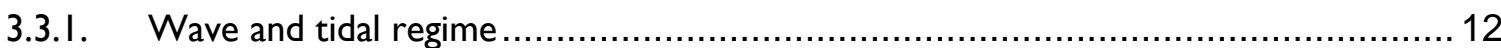

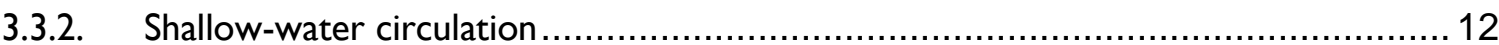

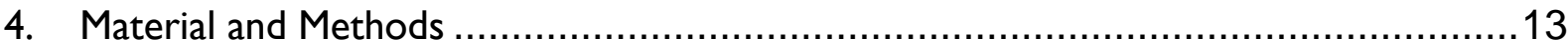

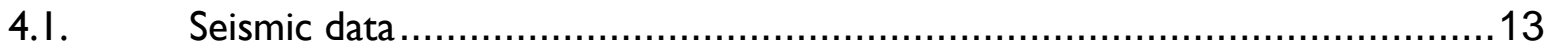

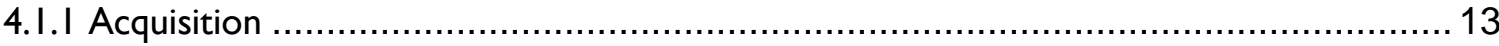

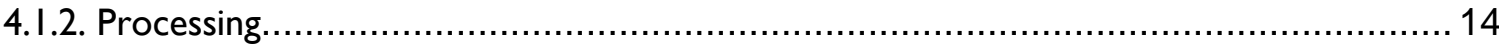

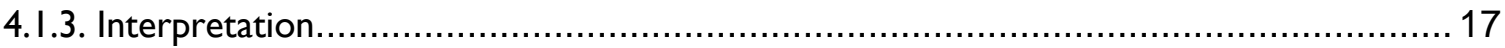

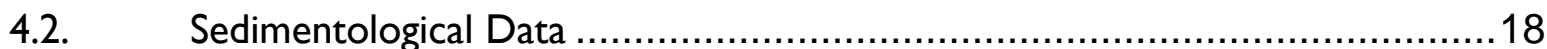

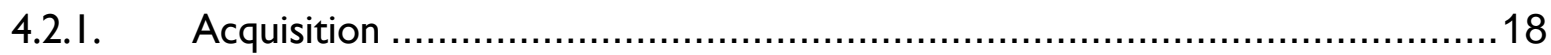

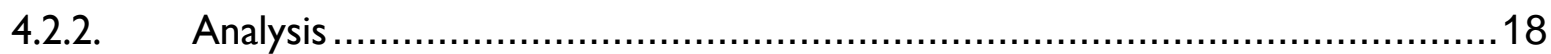

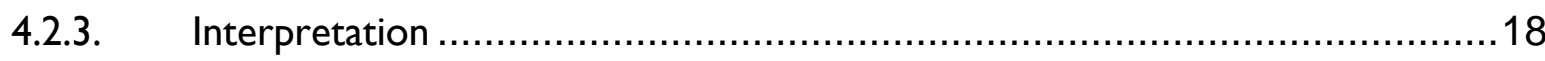


5. Results .20

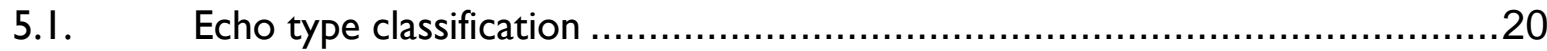

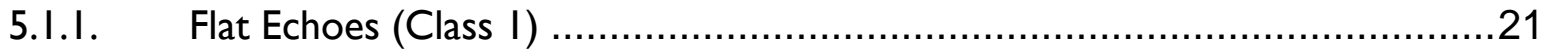

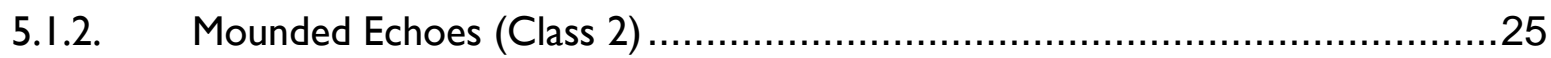

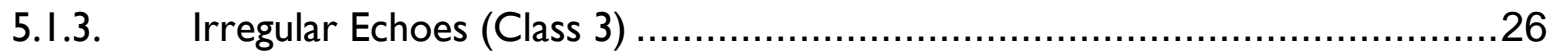

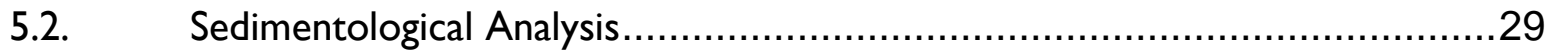

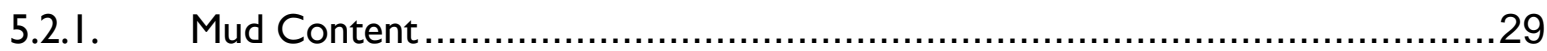

5.2.2. Calcium Carbonate Content ......................................................... 30

5.2.3. Spatial correlation between mud and calcium carbonate contents ................31

5.2.4. Spatial correlation between echo types and sedimentological data ................33

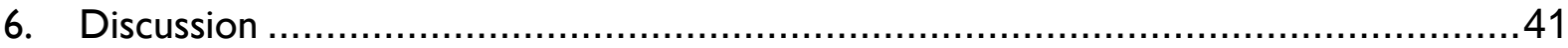

6.I. Sedimentological implications and sedimentary processes .......................46

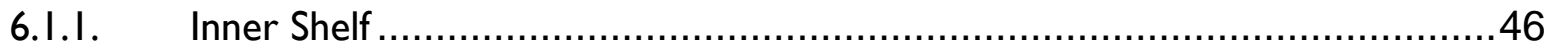

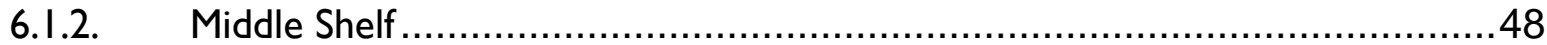

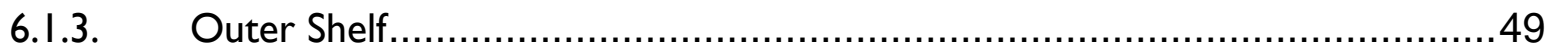

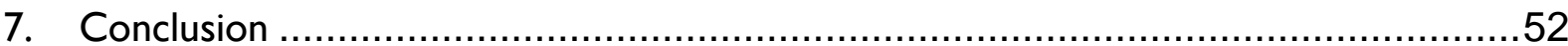

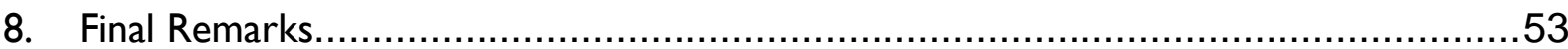

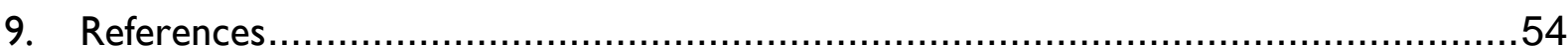




\section{Acknowledgment}

Agradeço à vida primeiramente, por me permitir a permear por caminhos que resultaram no aqui e no agora.

À minha família Cândida, Beatriz, Jairo e Simão, por acreditarem em mim, na minha jornada, nos meus sonhos... a vocês serei eternamente grata. Às minhas avós Maria e Isabel (in memoriam), minhas tias Adelina, Helena e Beth, meus tios Clovis e Geraldo, primos queridos Luana, Aline, Vitor e Juliana por sempre estarem comigo, independente do que eu trilhar. Amo todos vocês!

Ao meu orientador Michel e meu co-orientador Paco por terem tanta paciência comigo e me instruirem por esse processo inteiro que se chama mestrado. Tenho vocês mais do que como colegas de profissão, mas também amigos.

Um agradecimento ao Instituto Oceanográfico, minha segunda casa (às vezes parece até primeira) por sempre ter me acolhido e me amparado. Agradeço a todos os meus professores, aos técnicos de laboratório, à secretaria de pós graduação, à equipe do Navio Alpha Crucis. Sem vocês o meu trabalho não teria sido possível.

Aos meus colegas de laboratório, também conhecidos como lamaloqueiros, Pits, Rodrigo, Felipe, Rose e em especial Ivo e Jorge, que me ensinaram muitissimo e dedicaram atenção e tempo para me ajudar. Sem vocês eu não teria feito nem metade do que eu fiz. Obrigada!

Aos meus amigos do IO, em especial a inesquecível turma Turma Nine - Turma do Amor que tanto marcou a minha vida e ainda se faz presente (Giullia, Vaca, Cumpa, Cerejinha, Virjão, Camila, Danilo, Luiza, Paulinha, Bau, Martim, Domo, Ceci, Mari, Burns, Debinha, Isa, Stella, Suel, Liro).

À família que ganhei na capoeira e que tanto me ajuda a crescer e a acreditar em mim mesma. Gabi B., Gabi T., Julinha, Pedin, Nurietinha e Andrinha. Vocês são muito especiais para $\operatorname{mim} !$

Aos meus queridos amigos do intercâmbio em Granada, em especial mis compis de piso Arrate e Beatriz, por toda a ajuda na adaptação e por todas as tapas que dividimos.

Aos meus amigos Thaisa, Jessica, Vanis, Jana, Matheus e Jill que me acompanham mesmo que de longe há anos e sempre. Obrigada de coração! 
Agradeço muito ao Caian por ser esse companheiro maravilhoso que me faz crescer e cresce junto comigo. Te amo! Obrigada também a Rita e Waldemar por todo cuidado e apoio. Obrigada Rita por cuidar da minha saúde física, psicológica e espiritual.

Aos meus amigos do samba, que nessa reta final que foram tão presentes e me presentearam com muitas rodas, cerveja e risadas.

Quero fazer um agradecimento mais que especial à cultura popular brasileira: capoeira, dança afro, forró, jongo, roda de samba, samba de roda, samba de coco e tantas outras manifestações que resignificaram a minha vida e me mantiveram sã de corpo e alma nos últimos 2 anos.

Também agradeço ao CEME por toda semana me acolher e me prestar palavras de amor e coragem para seguir em frente.

À Fundação de Amparo à Pesquisa do Estado de São Paulo (FAPESP) pela concessão da Bolsa de Mestrado (Processo 2016/08029-6) e Bolsa de Estágio em Pesquisa no Exterior (BEPE Processo 20I6/2425I-0). 


\begin{abstract}
Sedimentary processes are critical geological phenomena in the evolution of continental margins. Environmental forces from various temporal and spatial scales control these processes. Due to the fast increase of anthropogenic activities in marine environments, these studies on sedimentary processes and their products are becoming increasingly necessary. In this context, geophysical data, such as high-resolution 2D seismic reflection profiles, are efficient tools to characterize sedimentary processes and deposits.

This study aimed to map and interpret different types of echo character on the continental shelf of the São Paulo Bight to increase the knowledge of the spatial variability of sedimentary processes in current-dominated shelf settings. With this aim, 120 seismic lines, almost 3200 $\mathrm{km}$ in length, have been analyzed in conjunction with $45 \mathrm{I}$ surficial sediment samples. Based on the broad-scale seafloor morphology, microtopography and seismic characteristics (e.g., sharpness, amplitude, continuity) of sub-bottom reflections, seven echo types distributed in three echo classes were identified in the study area.

Type $\mathrm{I}-\mathrm{I}$ is a flat seafloor with either no or low-amplitude sub-bottom reflectors, mainly observed in the middle shelf; type I-2 is a flat sea floor with medium to high-amplitude subbottom reflectors also found in middle shelf settings; type $\mathrm{I}-3$ is defined by a transparent acoustic response below the seafloor evolving downsection into a highly reflective pattern that covers most of the inner shelf; type 1-4 presents a flat seafloor molded by regularly spaced undulations, and it is restricted to the outer shelf; type 2-I consists of mounds with no internal reflectors also located on the outer shelf; type 3-I is an irregular echo with prolonged internal reflectors found around the São Sebastião Island; finally, type 3-2 is a broad irregular echo with high relief variations mainly found in the outer shelf.

The analysis of the seismic survey allowed recognizing that the distribution of the echoes reflects not only the composition of the seabed but also the sedimentary processes that acted during the deposition of the material. In the inner shelf and middle shelves, the Brazilian Coastal Current and the action of waves are the main processes responsible for the echo types found, while the outer shelf echo types are strongly influenced by the Brazil Current.
\end{abstract}




\section{Resumo}

Processos sedimentares são fenômenos importantes na evolução das margens continentais. Esses processos são controlados por forçantes de várias escalas espaciais e temporais. Devido ao rápido crescimento das atividades antropogênicas em ambientes marinhos, estudos sobre processos sedimentares e seus produtos tem se tornado cada vez mais necessários. Nesse contexto, dados geofísicos, como perfis de sísmica de reflexão de alta resolução, são ferramentas importantes na caracterização desses processos e depósitos.

O objetivo do estudo foi mapear e interpretar os tipos de caráter de eco na plataforma continental do estado de São Paulo visando aumentar o conhecimento a respeito da variabilidade espacial dos processos sedimentares em plataformas dominadas por correntes. Para alcançar esse objetivo 120 linhas sísmicas totalizando quase $3200 \mathrm{~km}$ em extensão foram analisadas em conjunto com $45 \mathrm{I}$ amostras sedimentares. Baseados na morfologia de macro e microescala e características sísmicas do sinal acústico de fundo como nitidez, amplitude e continuidade dos refletores, foram identificados 7 tipos de caráter de eco distribuídos em 3 classes (fundo plano, monticular ou irregular).

O tipo I-I apresenta fundo plano com refletores de sub fundo ausentes ou de baixa amplitude localizado principalmente na plataforma média; o tipo I-2 refere-se a um fundo plano com refletores internos com amplitudes médias a altas também presente na plataforma média; o tipo I-3 é definido por uma camada superficial transparente que é substituída em profundidade por uma camada altamente refletiva que cobre grande parte da plataforma interna; o eco I-4 apresenta fundo moldado por ondulações com localização restrita na plataforma externa; o tipo 2-I consiste em montes sem refletores internos localizado próximo a quebra da plataforma; o tipo 3-I é irregular com refletores internos prolongados e é encontrado ao sul da llha de São Sebastião; finalmente, o eco 3-2 é um eco irregular que apresenta grandes variações de relevo presente em grande parte da plataforma externa.

A análise dos dados sísmicos permitiu o reconhecimento de que os ecos respondem não somente a composição sedimentar superficial, mas também os processos sedimentares que atuaram durante a deposição do material. Nas plataformas interna e média, a Corrente Costeira Brasileira e a ação de ondas geradas pelos ventos são os principais processos responsáveis pela geração dos ecos encontrados, enquanto na plataforma externa, os tipos de eco são fortemente influenciados pela Corrente do Brasil. 


\section{List of Figures}

Figure I. Main physiographic domains of the ocean from Rothery and Wright (1998) I

Figure 2. Transmission and reflection of the seismic signal according to the acoustic impedance variation (Ayres Neto, 2000)

Figure 3. Geological location of the study area with 50, 100 and 200 meters isobaths............. 8

Figure 4. Sediment granulometry (adapted from Figueiredo and Tessler, 2004) ....................... 10

Figure 5. Sediment composition (adapted from Figueiredo and Tessler, 2004) ......................... I I

Figure 6. Geographical location of seismic and sedimentological data ......................................... 13

Figure 7. Example of delay and full-range of SEG-Y files. Each vertical line is a seismic line with its respective name.

Figure 8. Example of geographic coordinates of seismic lines. The numbers on each line are

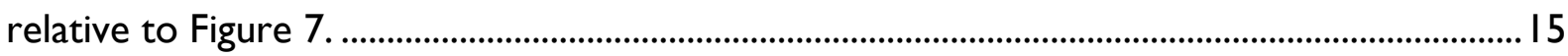

Figure 9. Seismic profile pre-processing (a) and post-processing (b) .......................................... 17

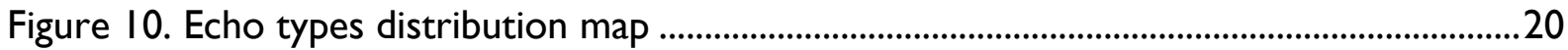

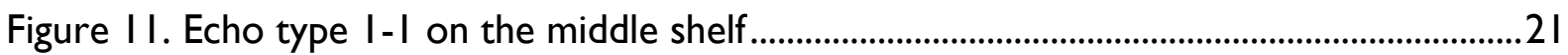

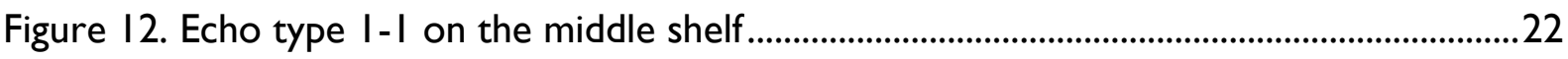

Figure I3. Echo type I-2 on the middle shelf perpendicular to the coast..................................22

Figure I4. Echo type I-2 on the middle shelf parallel to the coast ..............................................23

Figure I5. Echo type I-2 on the middle shelf parallel to the coast ............................................23

Figure 16. Echo type I-3 with low-amplitude internal reflector located on inner shelf

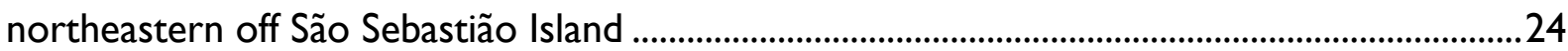

Figure 17. Echo type I-3 located on the southwestern inner shelf ..........................................24

Figure 18. Echo type I-3 with low amplitude internal reflectors located on the southwestern

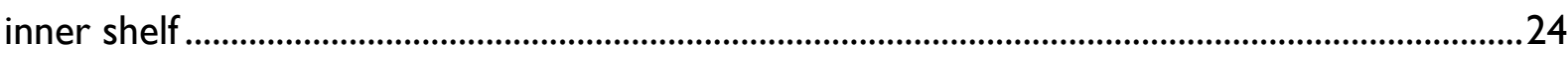

Figure 19. Echo type I-4 found on the northeastern outer shelf .............................................25

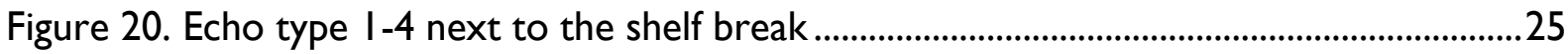

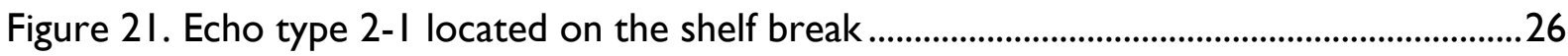

Figure 22. Echo type 2-I located on the shelf break ........................................................................26

Figure 23. Echo type 3-I located southeastern off São Sebastião Island........................................27

Figure 24. Echo type 3-I located southeastern off São Sebastião Island..........................................27

Figure 25. Echo type 3-2 located on the outer shelf .......................................................................28

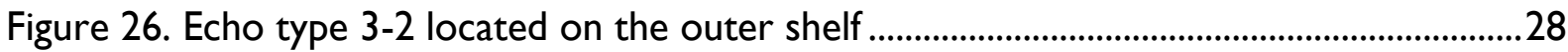


Figure 27. Echo type 3-2 on the outer shelf perpendicular to the coast

Figure 28. Echo type 3-2 with a flat sub-bottom reflector located on the southwestern outer shelf.

Figure 29. Echo type 3-2 on the southwestern outer shelf

Figure 30. Mud content on the São Paulo Shelf. Relatively stronger colors represent

relatively higher values of mud percentage in the surficial sediment.

Figure 3I. Calcium carbonate content on the São Paulo Shelf. Relatively stronger colors

represent regions where $\mathrm{CaCO}_{3}$ content is relatively higher.

Figure 32. Regions of mud and calcium carbonate similar contents

Figure 33. Distribution Map of echo types. Each number indicates a different environment in

terms of sedimentological facies and echo characters

Figure 34. Echo I-3 with lacks of signal penetration in depth with a high reflective internal reflector on the top

Figure 35. Intercalation of echoes I-2 and I-3 on Area 5.

Figure 36. Echo type I-3 located on Area 9

Figure 37. Echo type 3-2 on the southwestern outer shelf with the presence of depressions,

smooth surfaces and dipping and truncated internal reflectors. 38

Figure 38. Echo type 3-2 on the southwestern outer shelf with a rough surface 38

Figure 39. Echo type 3-2 on the outer shelf featuring several seafloor terraces... 38

Figure 40 . Echo type 3-2 on the outer shelf with parallel sub-bottom configuration 39

Figure 4I. Echo type 3-2 on the outer shelf with thickening and thinning of internal reflectors. 39

Figure 42. Echo types that correlate to high mud content. 42

Figure 43. Echo types that correlate to high low content. 42

Figure 44. Echo types that correlate to high calcium carbonate content. .43

Figure 45. Echo types that correlate to low calcium carbonate content 43

Figure 46. Summary of recent sedimentary processes and driving mechanisms interpreted in the study.

Figure 47. Vertical mean of power density measures with echo type 3-2 lines (Adapted from Fortes, 2018). 48

Figure 48. Transition area between echoes I-3 and 3-2 


\section{List of Tables}

Table I. Description and interpretation of echo types

\section{List of Acronyms}

BC - Brazil Current

BCC - Brazilian Coastal Current

$\mathrm{CaCO}_{3}-$ Calcium Carbonate

CW - Coastal Water

GPS - Global Positioning System

LGM - Last Glacial Maximum

NE - Northeast

NW - Northwest

SACW - South Atlantic Central Water

SE - Southeast

SSI - São Sebastião Island

SW - Southwest

TVG - Time Variable Gain

TW - Tropical Water

TWT - Two Way Time

UTM - Universal Transverse Mercator 


\section{Introduction}

The ocean floor is compartmentalized into geomorphological domains formed both by tectonic and sedimentary processes acting over long-term geological time scales through thousands of years. The main domains are the continental shelf, which borders the continents; the continental slope, which is the high declivity transition zone between the continental shelf and the ocean basins; the continental rise located at the base of the slope; and the abyssal plain (Figure I). The first three domains are genetically related to the adjacent continents and together are called continental margin (Teixeira et al., 200I; Harris et al., 20I4; Paris et al., 2016).

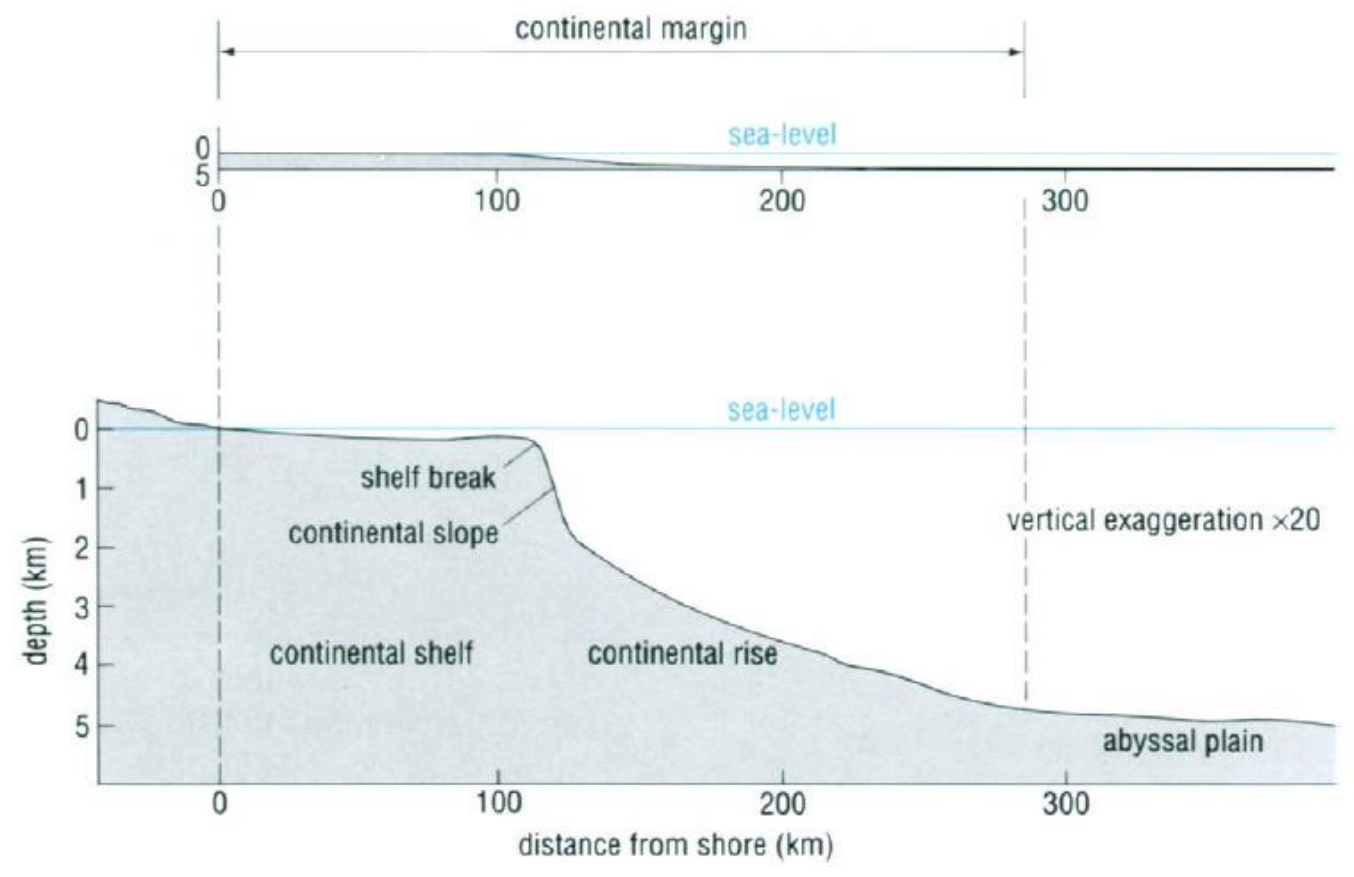

Figure I. Main geomorphological domains of the ocean from Rothery and Wright (1998)

Continental shelves constitute the low declivity submerged extensions of the continents, extending from the shoreline to the shelf break, which on average extends $80 \mathrm{~km}$ offshore at I30 m water depth (Kennett, 1982). On the southeastern Brazilian coast, it is more than I60 $\mathrm{km}$ wide (Mahiques et al., 2004).

Sedimentary processes on continental shelves are controlled by environmental forcings, which occur at different spatial scales (Pratson et al., 2007). Rivers are the most important source of sediment to the oceans with $84 \%$ of the total sediment load (Milliman and Meade, 
1983). After entering the ocean, the river flux loses velocity and competence depositing sediments at river mouths (Pratson et al., 2007). In low-gradient continental shelves, sediment deposition close to the shore will begin to build a delta (Elliott, 1986).

While rivers shape the profile of coastal plains and lead main deposition on the shelf, waves and currents are responsible for redistributing sediment along continental shelves (Wright and Nittrouer, 1995). The orbital movement of the waves in shallow waters remobilizes sediments, which are transported by local currents (Praston et al., 2007). Also, some geostrophic currents are strong enough to cause erosion (Poag and Mountain, 1987). The combined effect of sediment load deposition from rivers and waves and currents erosional activity eventually results in changes in the shoreline position (Pratson et al., 2007).

Sea-level oscillations constitute another important control on continental shelves evolution. Sea-level oscillations have modified continental shelves and sometimes even exposed and transformed them into coastal plains. During past sea level rises and falls, coastlines have been dislocated, resulting in the continuous formation and subsequent erosion of coastal environments by geological and hydrodynamical processes (Teixeira et al., 200I).

The study of sedimentary processes and resulting sedimentary products sculpting continental margins can be useful for several reasons. The deposits constituting the sedimentary record can provide information of past climate changes, which can be used to make predictions about future climatic trends. Also, they can record other natural processes, such as margin's hydrodynamic regimes, and anthropogenic impacts, such as pollution in drainage basins and river effluents and waste disposal. These studies are also valuable for the prospection and extraction of natural resources, such as sandy sediments for beach replenishment, gas hydrates, and other mineral resources of economic value. Finally, they are also used for the site assessment for the installation of communications cables, drilling platforms and other man-made structures. 


\section{I.I. Seismic Methods}

Geoacoustics methods are based on the emission, transmission, and reflection of acoustic waves between two or more means with different physical properties (Ayres Neto, 2000). A commonly used geoacoustic method in shallow marine studies is the seismic reflection (Kearey, 2009). This technique consists in the generation of seismic waves that travel to the seafloor. Then, the travel time of these waves is measured from emission to reception. Based on this travel time, it is possible to locate the interfaces where seismic waves are reflected or refracted (Ayres Neto, 2000). Acoustic methods are nondestructive by nature, eliminating the need to get into physical contact with the investigated environment. Another advantage is that acoustic methods are acquired continuously while the ship travels along the track, resulting in a higher spatial coverage and lower costs (Souza, 2006).

The reflection of the acoustic signal or the refraction to another layer only occurs when there is a significant difference of acoustic impedance between the means crossed by this wave (Figure 2). Acoustic impedance is the product of the density of a medium and the velocity of the sound across the media (Mosher and Simpkin, 1999). The higher the acoustic impedance contrast between the two media, the more energy is reflected back to the receiver (Souza, 2006).

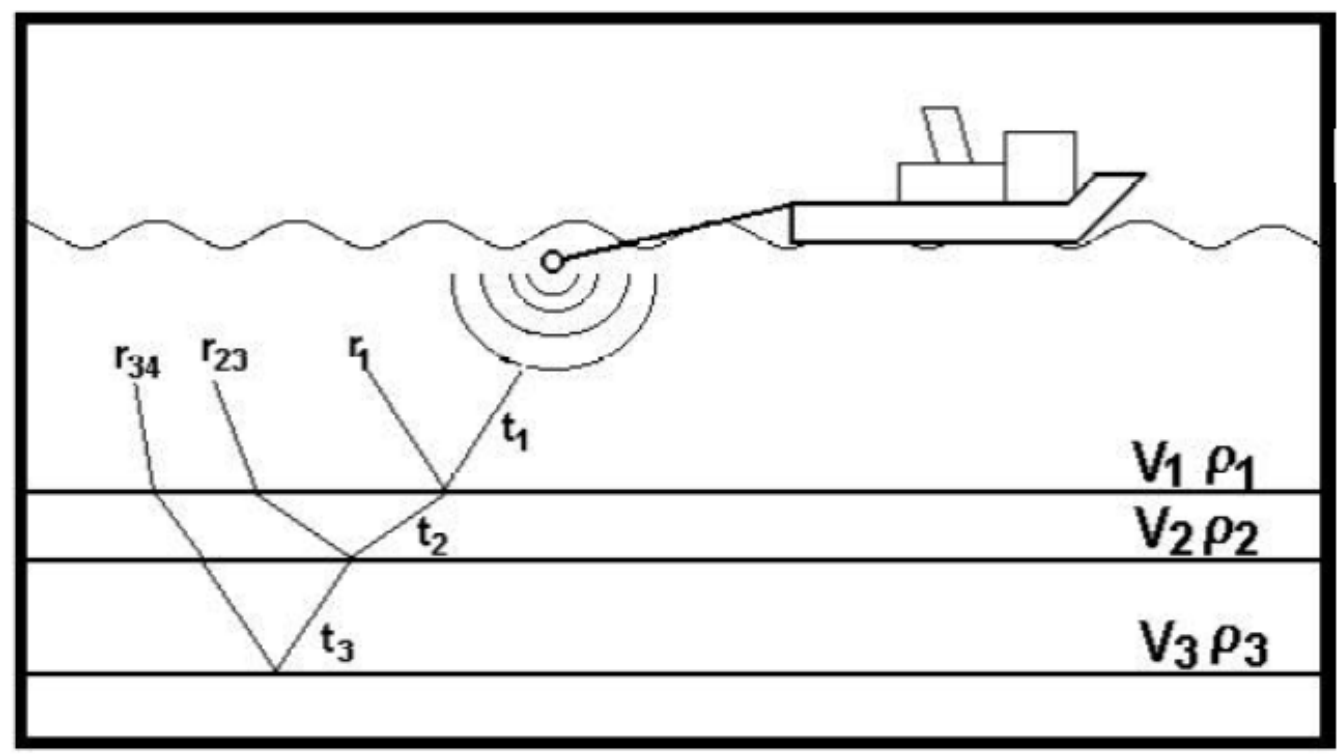

Figure 2. Transmission and reflection of the seismic signal according to the acoustic impedance variation (Ayres Neto, 2000) 
When the acoustic pulse returns to the receiver, a graphic trace is generated representing reflectors that have been identified along the trajectory. The print sequence of several acoustic traces is called echogram (Cooke et al., 2007). Echograms can characterize not only the bottom surface but also the subsurface, illustrating a geological section (Damuth, 1975). An important concept on seismic reflection analysis and the interpretation of geological sections is the vertical resolution, which is the measurement of the capacity to recognize low spaced individual reflectors (Kearey, 2009). Other important concepts are the frequency and penetration of the acoustic signal in the sediment. The higher the wave frequency, the higher the absorption by the medium (Jones, 1999), thus the lower the signal penetration in the sediment. There are many kinds of seismic sources that send specific acoustic signals at a given frequency. Therefore, the equipment to be chosen is a factor of the study goal, which includes the intended acoustic signal penetration and vertical resolution. Due to the indirect nature of the seismic methods, it becomes necessary to validate the seismic information. The validation is usually made by combining acoustic and sedimentological data.

In the case of shallow water studies that target the surficial sediment layers, highresolution reflection seismic sources such as Chirp are extensively used (Damuth, 1975, 1978, 1980; Damuth and Hayes, 1977; Pratson and Laine, 1989).

Indeed, geoacoustic tools have demonstrated to be very efficient in the understanding of sedimentary processes. Acoustic characteristics and physical properties of sediments are important variables that respond to geological events, which can be preserved in the sedimentary record (Mendoza et al., 2014). The intrinsic ability of sediments to absorb and scatter sound waves allows the discrimination and classification of different sedimentary facies (Briggs et al., 2002). 


\section{I.2. Mapping Echo Characters}

The characteristics of the return signal (e.g., acoustic penetration, seafloor topography, presence, absence, sharpness, number, and shape of the sub-bottom reflectors) contained in high-frequency echograms can be approached with the concept of echo character. The types and distribution of echo characters can be used to generate an echo character map (Damuth, 1980), by following a number of steps: (I) echogram examination; (2) classification of echo types according to echo sharpness and continuity, microtopography and bottom morphology; (3) mapping of echo types in each acoustic line; (4) interpolation of echo types taking into account the lateral spacing between acoustic lines (Damuth, 1980).

Echo types are mainly controlled by surface topography, subsurface geometry and texture of the surface and subsurface sediments (Damuth, 1975). Therefore, the spatial mapping of echo character correlated with sediment samples, can be used as a basis for the interpretation of sedimentary processes in the desired study area (Souza, 2006).

Most interpretations of erosional and depositional processes based on echo character analysis have been conducted in deep- water environments, (e.g., Damuth, 1975; Damuth and Hayes, 1977; Damuth, 1978; Mullins et al., 1978; Pratson and Laine, 1989; Rad and Tahir, 1997; Reddy and Rao, 1997; Lee et al., 2002; Damuth and Olson, 2015). The derived echo character classifications improved the regional spatial variability picture of gravitational versus currentcontrolled deep-water processes.

Later, echo character analysis was also applied to shallow-water environments, such as bays, lagoons, channels and rivers (e.g., Quaresma et al., 2000; Belo et al., 2004; Catanzaro et al., 2004; Garcia-Garcia et al., 2004; Bexiga, 2006; Van den Bergh et al., 2007; Palomino et al., 2009; Veronez Junior et al., 2009; Felix, 20I2; Magrani and Ayres Neto, 20I4; Silva et al., 20I4) and continental shelves (Boni, 2014; Frappa and Pujos, 1994; Figueiredo and Nittrouer, 1995; Hong and Chen, 2000; Chough et al., 2002; Ayres Neto et al., 2009; and Lee et al. 20I3). These studies were helpful to reveal a suite of genetic, sedimentary and hydrologic processes acting on continental shelves. These processes are either related to sediment input from rivers (Ayres Neto et al., 2009; Boni, 20I4; Chough et al., 2002; Figueiredo and Nittrouer, 1995; Lee et al., 2013) or to different types of water masses displacements, due to tidal currents (Ayres 
Neto et al., 2009; Chough et al., 2002; Lee et al., 2013), wind-driven currents (Chough et al., 2002) or even upwelling events (Hong and Chen, 2000).

In spite of the continental dimension of the Brazilian coast, only a few echo character studies have been conducted in detail on the continental shelf such as Boni (20I4) in the shelf adjacent to the Doce River, and Ayres et al. (2009) in the northern Brazilian shelf. The echo types reported in these areas are highly variable but usually distinct.

Damuth and Hayes (1977) conducted a study to map echo types in the East Brazilian Margin. However, very few seismic lines have been acquired on the continental shelf, and only one echo has been identified. This echo type has been described as a distinct flat echo with low signal penetration and no sub-bottom reflectors. 


\section{Goals}

The combined analysis of echo types and sedimentological data provides information about the bottom lithology and recent sedimentary processes. Under this assumption, this study aims to define and map the echo types found in an extensive area of the upper continental margin of the São Paulo Bight and to interpret each echo type regarding the sedimentary process. To achieve this objective, the following steps have been executed:

- To identify differences of echoes characters on the shelf;

- To create types of similar echo characters;

- To describe each echo character type;

- To build a distribution map of echo character types;

- To compare the echo character with sedimentological data;

- To interpret the defined echo characters in terms of sedimentary processes. 


\section{Study Area}

The study area is located on the continental shelf of the São Paulo Bight between $23.5^{\circ} \mathrm{S}$ and $26.0^{\circ} \mathrm{S}$ and between $46.5^{\circ} \mathrm{W}$ and $44.0^{\circ} \mathrm{W}$ (Figure 3). The continental shelf width varies from 70 and 230 kilometers and exhibits declivities from $0.05^{\circ}$ to $0.11^{\circ}$ meters (Mahiques et al., 20I0). The continental shelf break occurs between 120 and 180 meters water depths (Mahiques et al., 2004).

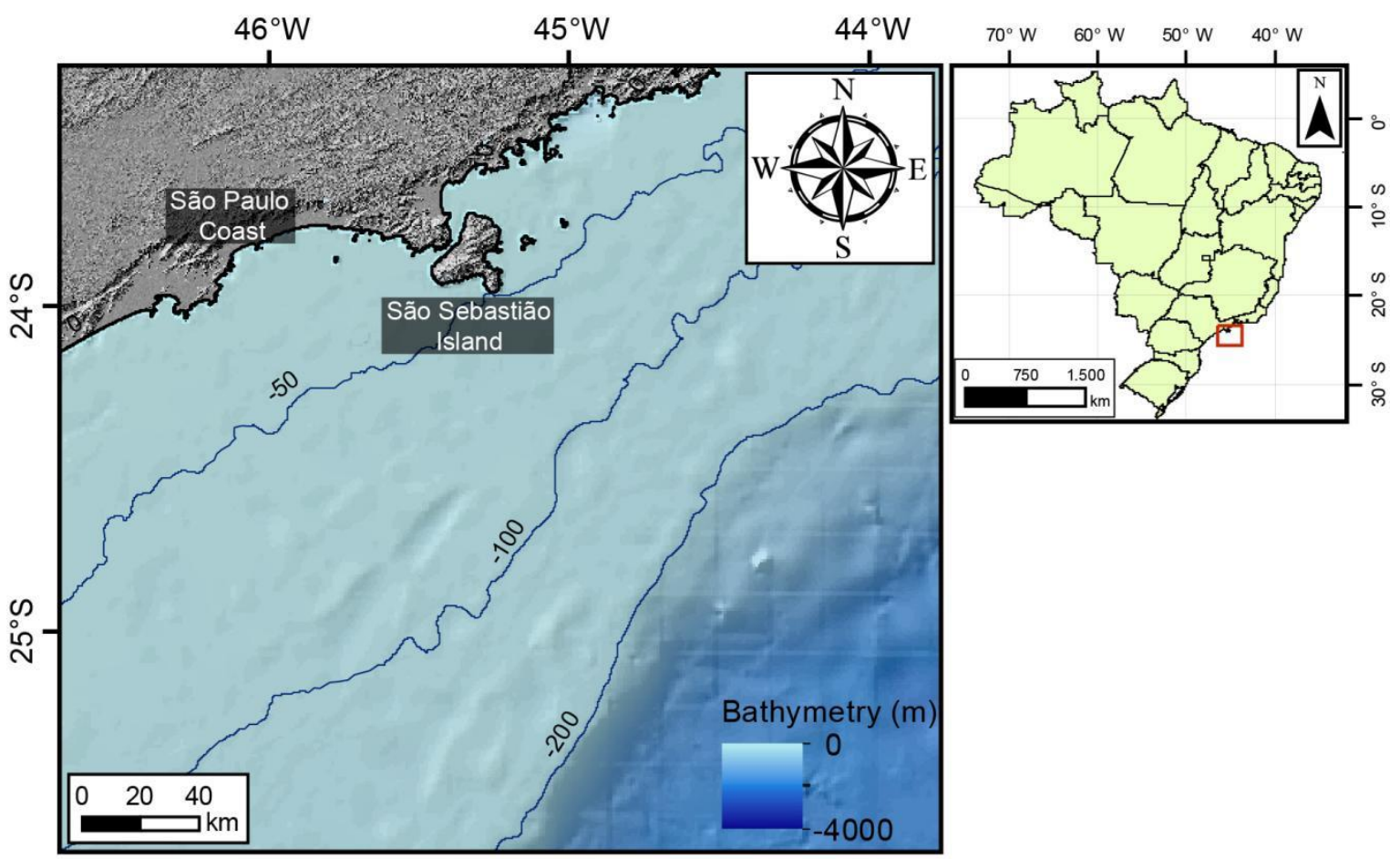

Figure 3. Geological location of the study area with 50, 100 and 200 meters isobaths

\section{I. Geological Evolution and Sea-Level Changes}

The geological evolution of the study area is determined by the genesis and development of the South Atlantic Ocean, marked by the Santos Basin subsidence (Meisling et al., 200I) and the Serra do Mar uplift (Almeida and Carneiro, 1996). As a consequence of the Serra do Mar uplift, most of the rivers flowed to the inner part of the continent feeding the Paraná and de la Plata drainage basins (Mahiques et al., 2004).

During the Quaternary, the shelf largely evolved as a result of glacioeustatic sea-level changes driving successive transgressions and regressions (Mahiques et al., 2004). In the study area, the two most recent transgressive events are recorded in the coastal plain. Thus, the sea 
level reached around 10 and 5 meters above the current sea level after the penultimate (I 20.000 years BP) and the last postglacial transgression (5.600 years BP), regionally known as the Canáneia and Santos transgressions, respectively (Suguio and Martin, 1978).

Between these transgressive periods, the global sea level fell around 120 meters, culminating in a sea-level lowstand between 19,000 and 22,000 years BP (Yokoyama et al., 2000). As a consequence, the coastal plain and the continental shelf have been exposed. These coastlines variations were responsible for differences in the sedimentation regimes due to changes in oceanic circulation patterns. After the Last Glacial Maximum (LGM) $(20,000$ years BP), the influence of coastal waters in the transport and deposition of sediments has decayed and the Brazil Current and its eddies have changed their geographical position (Mahiques et al., 1999, 2002).

\subsection{Surficial Sediment Patterns}

The continental shelf of São Paulo is characterized by the existence of two sectors (southwestern and northeastern), which exhibit distinct sedimentological and geomorphological characteristics. The São Sebastião Island (SSI) marks the boundary between those sectors (Mahiques et al., 1999).

The southwestern sector is dominated by terrigenous sediments, particularly the inner and middle shelves that are covered by very fine sands and some patches of fine sands; The northeastern sector exhibits mud and very fine sands on the inner shelf and fine sands on the middle shelf. The outer shelf along the study area is covered by mud and very fine sands with scarce amounts of coarse sands (Figure 4). However, in the northeastern sector bioclastic sediments are also frequent on the middle to outer shelf (Figure 5).

The surface sediment distribution is interpreted as a primary response to local bathymetry and hydrodynamic conditions (Mahiques et al., 2004). In general, the influence over the inner shelf of wind-generated waves and the Brazilian Coastal Current (BCC), which is associated with cold fronts (Castro and Miranda, 1998), accounts for the dominance of fine to very fine sands. In the southwestern sector, the coastline orientation and the isobaths pattern parallel to the coast induce a more effective wave action on the inner shelf, largely preventing mud sedimentation. In the northeastern sector, the complex coastline physiography and the 
occurrence of many islands in the inner shelf favor mud deposition, as wave activity is diminished in this sheltered environment (Figure 4) (Mahiques and Souza, 1999; Mahiques et al., 2007; Mahiques et al., 2008).

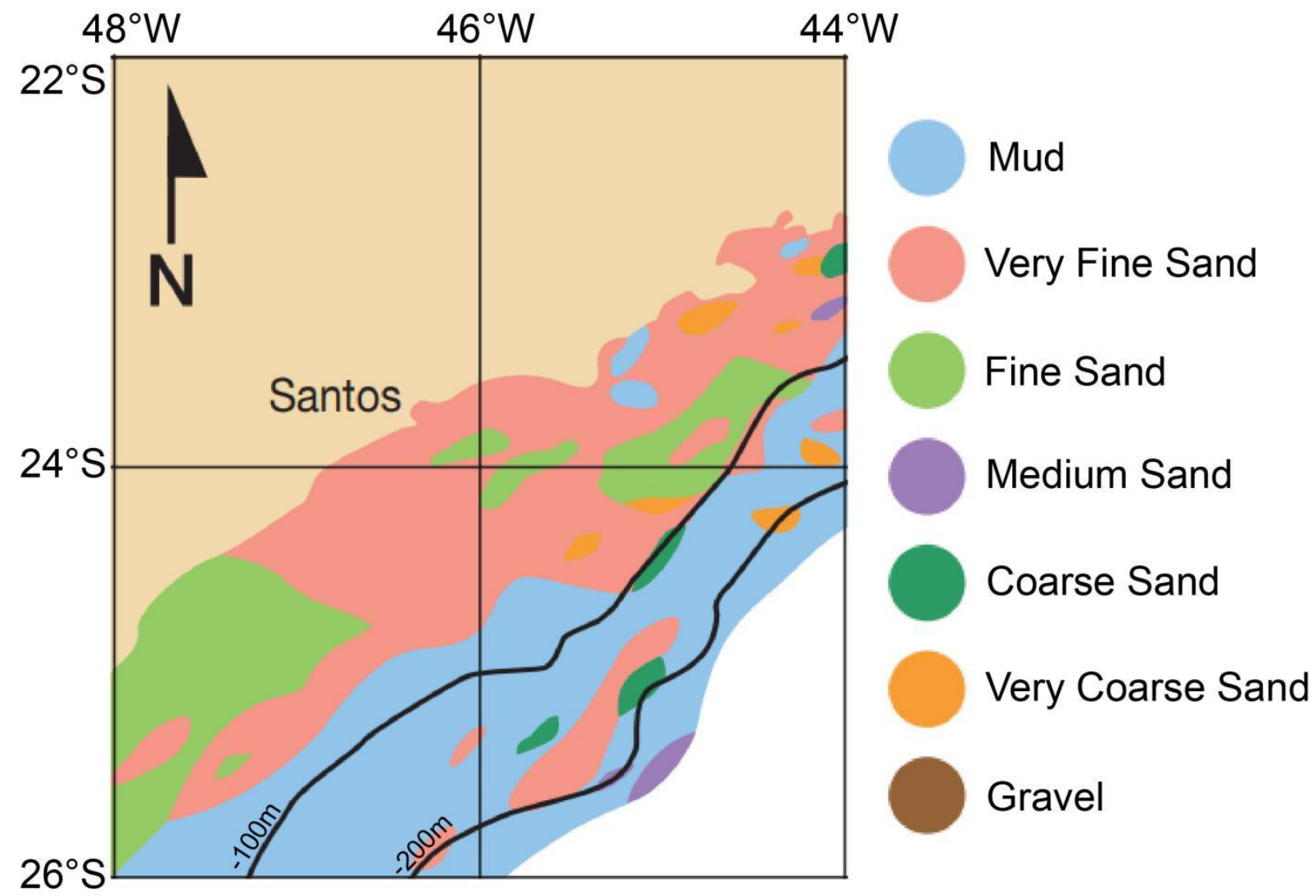

Figure 4. Sediment granulometry (adapted from Figueiredo and Tessler, 2004).

The most important source of recent sediments to the southwestern Atlantic shelf is the La Plata River plume, whose sedimentary influence can be recognized up to $25^{\circ} \mathrm{S}$ (Mahiques et al., 2008). In the northeastern sector, recent sediments are mainly derived by the many small rivers located in the São Sebastião, Caraguatatuba, and Ubatuba cities (Vieira et al., 2018). The origin of bioclastic sediments is related to deposition of calcareous algae on the northeastern outer shelf (Conti and Furtado, 2016) and to high biological productivity induced by shelf-edge upwelling (Campos et al., 1999). 


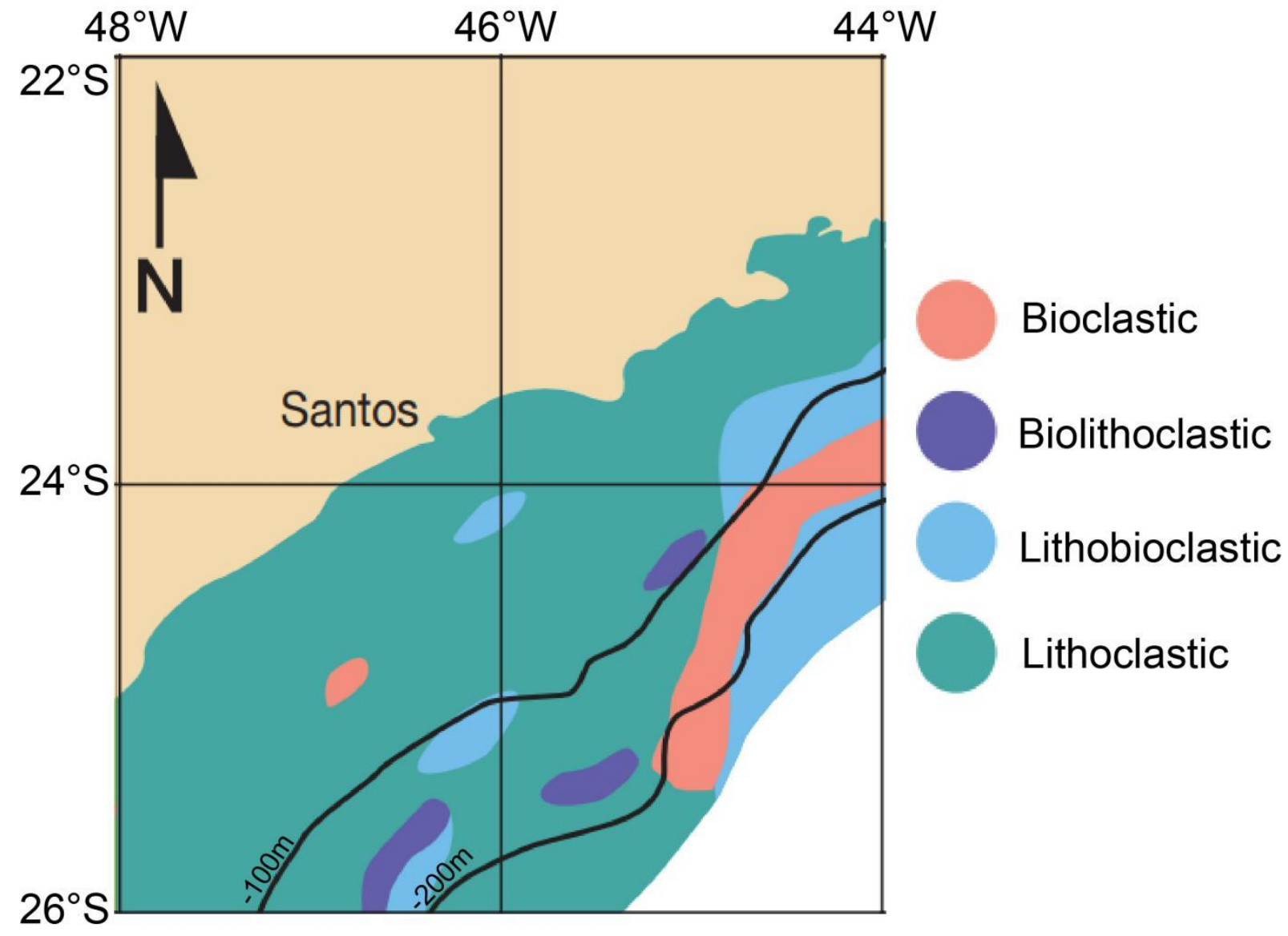

Figure 5. Sediment composition (adapted from Figueiredo and Tessler, 2004). 


\subsection{Oceanographic Regime}

\subsection{Wave and tidal regime}

Waves in the São Paulo continental shelf present a mean height of 1.8 meters and a mean period of 8.6 seconds. The highest waves occur between April and July (austral fall and winter), when they have an average height of 5 meters. The most frequent waves are from the south and southwest, although they are not very energetic, since they are not capable of transporting a significant amount of sediments from local beaches (Lourenço, 20I2). In contrast, waves from the east-southeast, southeast and south-southeast can resuspend high amounts of sediments. The São Paulo continental shelf is influenced by micro-tides transverse to the coast (Alves, 1992).

\subsubsection{Shallow-water circulation}

The inner shelf (between the coast down to 50 meters water depth) is mainly affected by the Coastal Water $\left(\mathrm{CW}\right.$; temperature around $24^{\circ} \mathrm{C}$; salinity lower than 35$)$. The middle shelf (between 50-90 m water depths) is defined by the seasonal displacements of the Tropical Water (TW; temperature higher than $24^{\circ} \mathrm{C}$; salinity higher than 36 ) (Castro, 20I4). Over the inner and middle shelf, alongshore water transport is mainly controlled by large-scale wind regimes (Dottori and Castro, 2009). An inner shelf current flowing to the NE and named Brazilian Coastal Current (BCC) is relatively slow compared to the Brazil Current, but highly energetic, although BCC concentrates almost all the energy in small-scale perturbations and eddy activity rather than in the mean flow. The BCC occurs over the Southern Brazilian Continental Shelf during the spring and wintertime and reaches up to $25.2^{\circ} \mathrm{S}$ in August every year (Souza and Robinson, 2004). Trade winds, which occur at austral winter, push coastal water towards out of the coast favoring upwelling events (Brandini et al., 20I4).

The outer shelf is mainly defined by the South Atlantic Central Water (SACW; Temperature between 6 and $20^{\circ} \mathrm{C}$; Salinity between 34 and 35). The Brazil Current (BC) flows to the SW in the outer shelf and influences sediment transport and deposition. From November to March (austral summer), SACW intrusion related to the Brazil Current meandering and its interaction with the local topography (Campos et al., 1999) occurs towards the coast. 


\section{Material and Methods}

\section{I. Seismic data}

\section{I.I Acquisition}

A total of 3,I48 km of high-resolution seismic profiles have been collected in the study area from $23.5^{\circ} \mathrm{S}$ to $26^{\circ} \mathrm{S}$ and $46.5^{\circ} \mathrm{W}$ to $44^{\circ} \mathrm{W}$ in the São Paulo continental shelf by the Oceanographic Institute of the University of São Paulo during four oceanographic surveys: NAP-GeoSEDex in February 2013; Talude in July 2016; Contornitos in December 2016; and MudBelts in June 2017 (Figure 6).

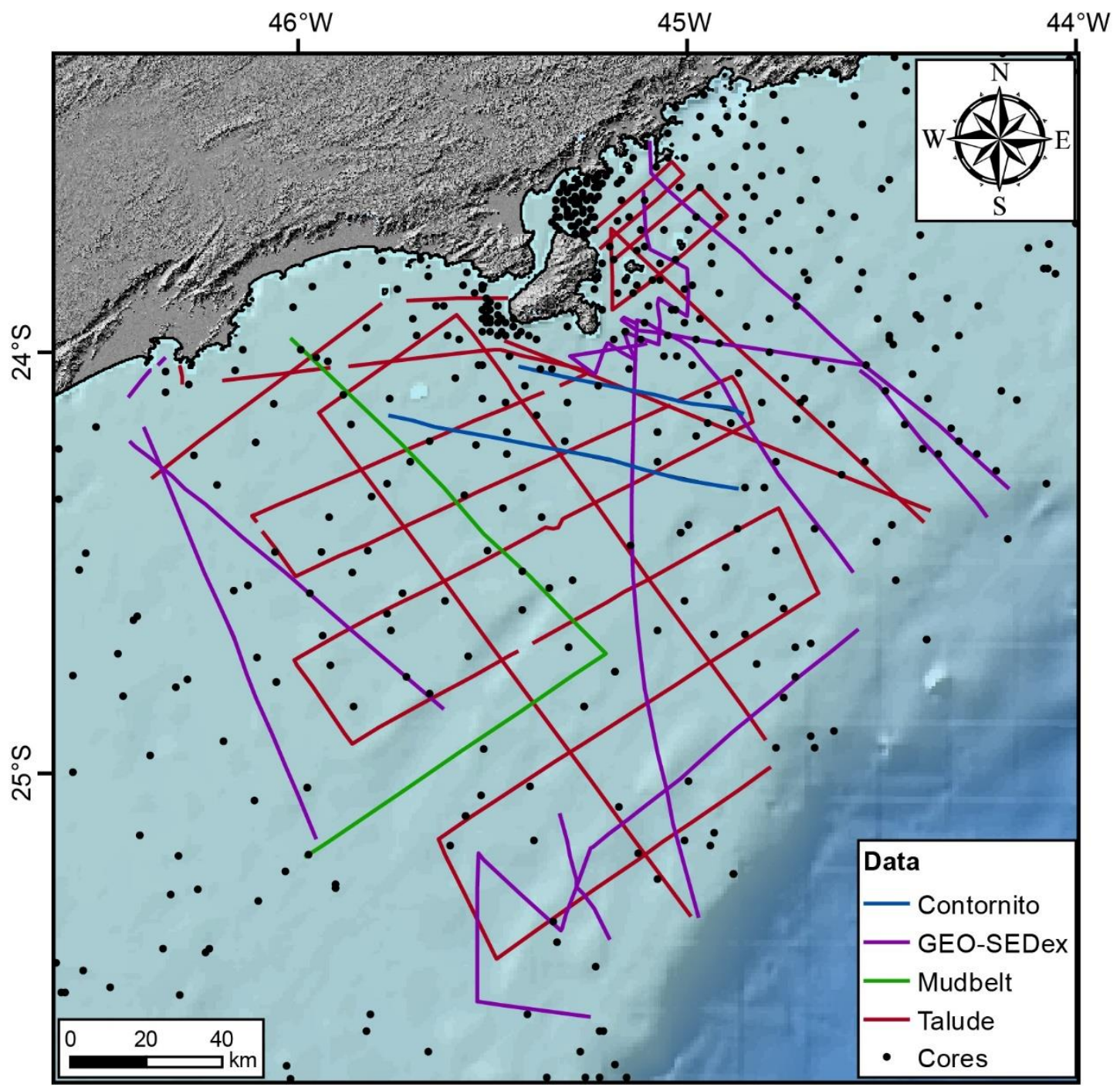

Figure 6. Geographical location of seismic and sedimentological data 
The seismic source was a 3260 Knudsen chirp sonar system with a $3.5 \mathrm{KHz}$ frequency. Data were acquired in digital KEB format with simultaneous positioning through a GPS receiver connected to the acquisition software SounderSuite ${ }^{\mathrm{TM}}$ for Windows. The general acquisition parameters were: transmit power I, gain value from 2 to $8 \mathrm{~dB}$ and TVG (time variable gain) of $10 \log R$. The data acquisition windows $(50-100 \mathrm{~m})$ and the recording delay were changed during the acquisition according to the water depth (from 0 to 200 meters), seafloor declivity and signal penetration. SW-NE oriented lines are spaced at variable intervals between 4 and $46 \mathrm{~km}$, whereas SE-NW oriented lines are spaced at variable intervals between 6 and $29 \mathrm{~km}$. The size of the seismic files was time dependent, as the files were stored during successive 30 minutes time intervals.

\section{I.2. Processing}

Seismic data were initially converted to SEG-Y, and the internal structure was checked: information on trace headers such as geographical position, trace number, and delay. Coordinates were transformed to UTM using a Matlab ${ }^{T M}$ script called SEG4KING, freely available and developed by the Marine Geosciences Department of the Spanish Institute of Marine Sciences (http://gma.icm.csic.es/en/software).

The seismic files were subsequently grouped in RadExPro ${ }^{\mathrm{TM}}$ software according to the acquisition interval, recording delay (Figure 7) and line orientation (Figure 8). As a consequence, a total amount of 120 seismic lines constitute the basis of the present work. 


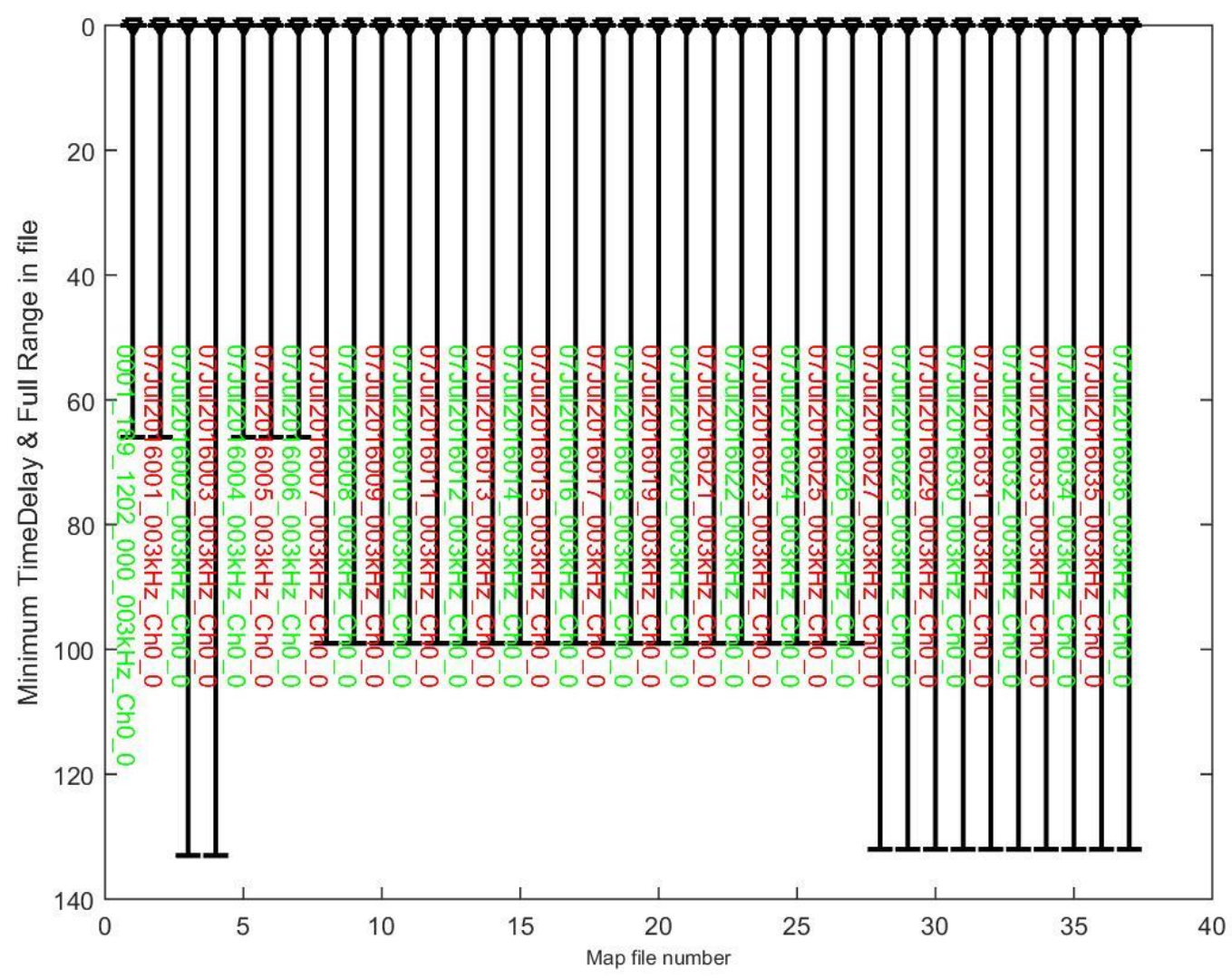

Figure 7. Example of delay and full-range of SEG-Y files. Each vertical line is a seismic line with its respective name

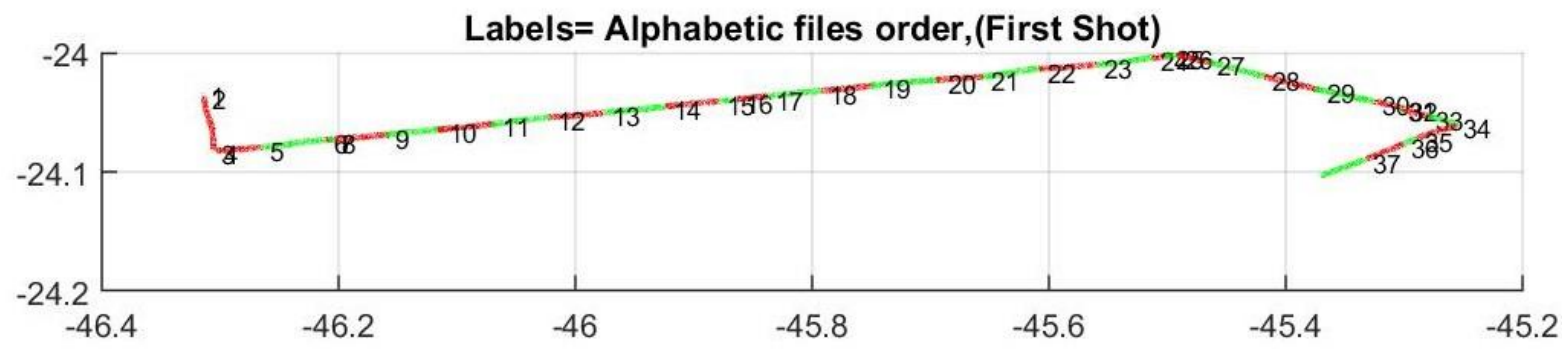

Figure 8. Example of geographic coordinates of seismic lines. The numbers on each line are relative to Figure 7

SEG-Y files were subsequently processed using the RadExPro ${ }^{\mathrm{TM}}$ software according to the following steps:

- Import

In data import, a flow called Header Averager was included to replace duplicated positioning values using a moving average to avoid mapping problems. 
- $\quad$ First Break Picking

The bottom surface was delineated using a manual picking option, since an automatic picking was found to be useless due to various noises found in the water column.

- Gains

An exponential correction that multiplies every sample by an exponential function has been applied. That correction allows approximate compensation for intrinsic attenuation in the media (DECO Geophysical Software Company ${ }^{\top M}$, 20I4).

- Static Corrections

At this step, the noises in the water column were removed, and a swell filter was applied to smooth the oscillations found on the bottom surface caused by waves at the time of data acquisition (Figure 9).

- Export

The final step was to export the processed data into a SEG-Y format to proceed to the interpretation in the Kingdom ${ }^{\mathrm{TM}}$ IHS software. 

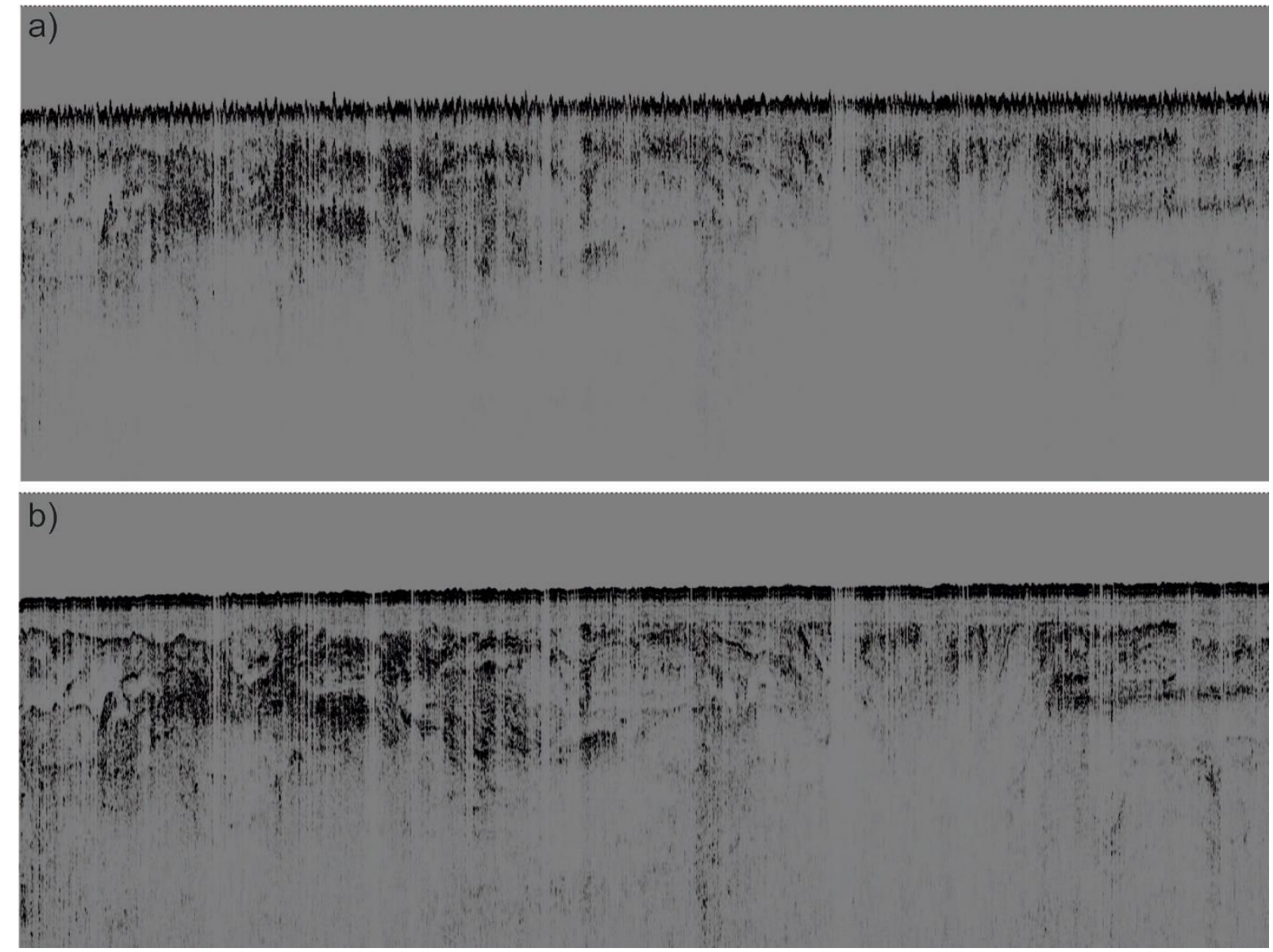

Figure 9. Seismic profile pre-processing (a) and post-processing (b)

\section{I.3. Interpretation}

The determination of echo characters was made by displaying seismic profiles in the IHS Kingdom ${ }^{\mathrm{TM}}$ software by defining the seismic profile scales and the vertical exaggerations. Echo characters were classified using initial schemes focused on deep-water settings (Damuth, 1975 and 1980; Damuth and Hayes, 1977; Pratson and Laine, 1989). However, none one of these papers deals with shelf echo types in detail. Therefore, several additional studies conducted on continental shelves have also been used as a basis for interpretation and classification of echo types (Reddy and Rao, 1997; Von Rad and Tahir, 1997; Chough et al., 2002; Van den Bergh et al., 2007; and Lee et al., 20I3). In the present study, a $1500 \mathrm{~m} / \mathrm{s}$ sound velocity has been applied to convert two-way travel time into water depths. 
The echoes have been defined and traced in each seismic profile on Kingdom ${ }^{\text {TM }}$ IHS software. In some cases, the transition between two different echoes showed mixed characteristics. In such areas and for classification purposes, the marked echo type was the most prominent echo.

The horizons have been exported with the respective geographical coordinates to build an echo character map in ArcMap ${ }^{\mathrm{TM}}$. Finally, a map of echo types distribution has been built by integrating both seismic and sediment-derived information.

\subsection{Sedimentological Data}

\subsection{Acquisition}

A total of 45 I superficial sediment samples collected between 1992 and 2017 by the Oceanographic Institute of the University of São Paulo were included in this study (Figure 6). The sampling of the seabed surface sediments was performed using box-corer. Subsamples were used to analyze the content of calcium carbonate $\left(\mathrm{CaCO}_{3}\right)$ and grain-size.

\subsubsection{Analysis}

Sediment samples were analyzed at the Sedimentology Laboratory of the Oceanographic Institute of the University of São Paulo. In all the samples, only the topmost 2 $\mathrm{cm}$ were retrieved for the sedimentological analysis.

The determination of the granulometric characteristics was performed in a Malvern ${ }^{\mathrm{TM}}$ 2000 sedimentometer after the elimination of calcium carbonate and organic matter contents.

The calcium carbonate content was determined by calculating the difference in weight of the sediment prior and after acidification. Values are reported in percentages of dry weight.

\subsubsection{Interpretation}

The sedimentological data have been imported in $\operatorname{ArcMap}^{\mathrm{TM}}$ to build interpolated maps of mud and calcium carbonate contents. The Inverse Distance Weighted interpolation method was used. This method determines cell values using a linearly weighted combination of all 
samples. The weight is a function of the distance inverse, i.e., the higher the distance, the lower the influence of that point to a specific area $\left(\operatorname{ArcGIS}^{T M} E S R I, 2016\right)$. Isolines have been created every 20 meters using the Contour Tool of $\operatorname{ArcMap}^{\mathrm{TM}}$. 


\section{Results}

\section{I. Echo type classification}

A total of 7 echo types divided into three classes are identified by considering three criteria: (a) the morphology of the seafloor reflection; (b) the acoustic character of the seafloor reflection (e.g., sharp, semi-prolonged, prolonged); and (c) the penetration of the acoustic signal and presence or absence of sub-bottom reflections. These echo types are classified into three principal classes according to the nature of the seafloor morphology: flat echoes (class I), mounded echoes (class 2) and irregular echoes (class 3 ). The area covered by each echo type is illustrated by Figure 10.

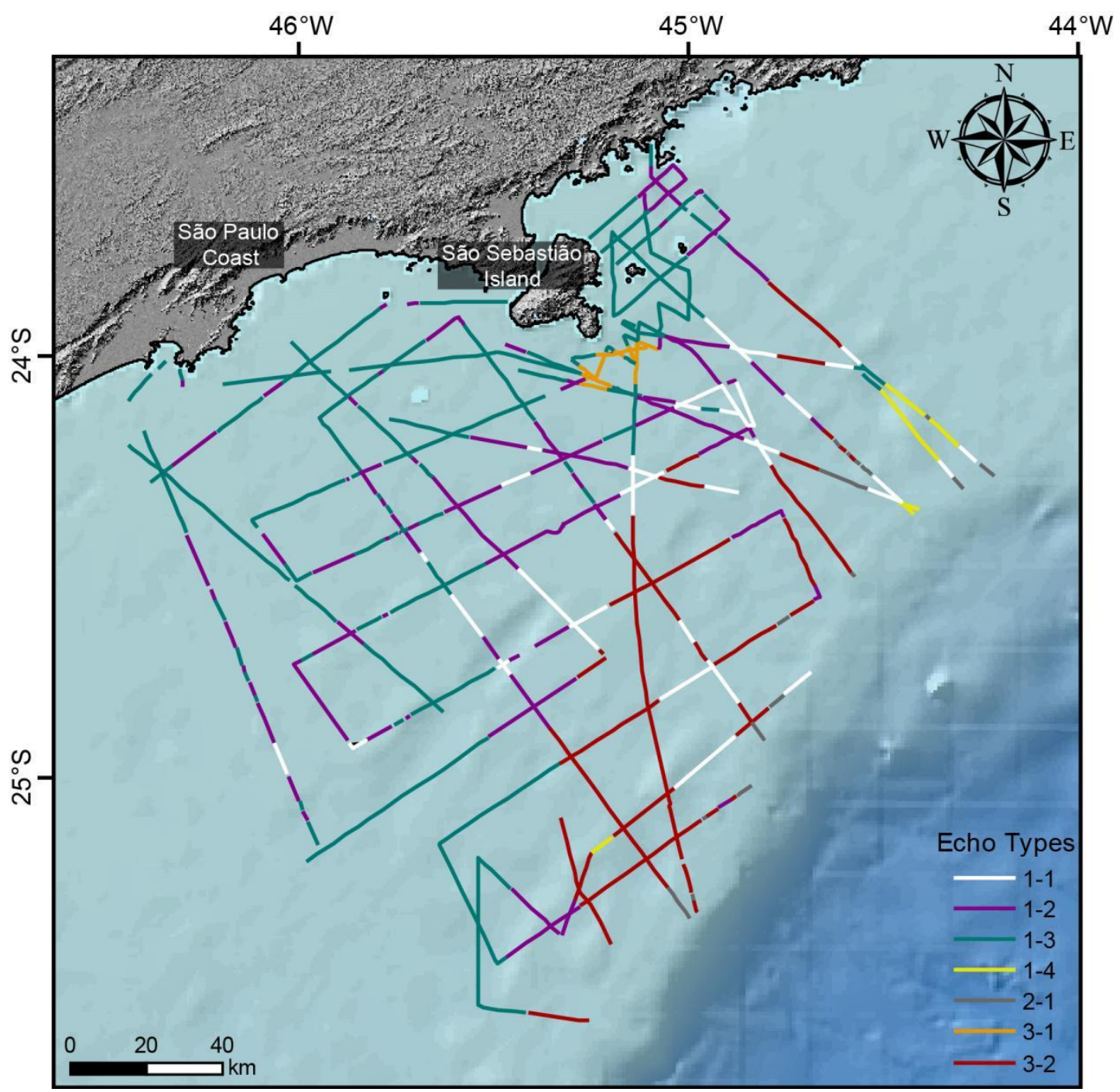

Figure I0. Echo types distribution map 


\section{I.I. Flat Echoes (Class I)}

The echoes in this class present a flat bottom echo and are classified according to the presence or absence of sub-bottom reflectors and, if existent, the configuration of sub-bottom reflectors. This class is the most widely distributed on the shelf, representing $75.4 \%$ of the total surveyed area.

\section{I.I.I. Type I-I. Flat sea floor with either no or low-amplitude sub- bottom reflectors}

This echo type (Figures II and I2) is characterized by a flat or gently sloping with a slightly irregular relief, sharp to semi-prolonged bottom echo which presents low acoustic penetration and no or low-amplitude sub-bottom reflectors. This echo type is predominantly found on the inner and middle shelf and close to echoes 2.I and 3.2. Its occurrence is also associated with inter mound areas. Echo type I-I represents II.7\% of the surveyed area with 369 linear kilometers.

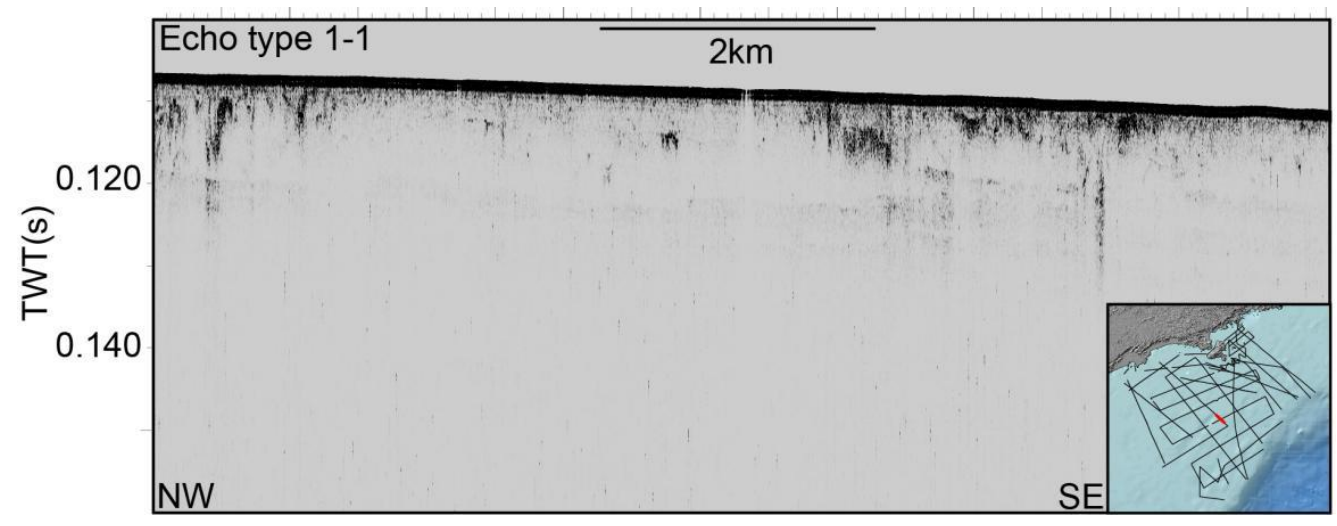

Figure II. Echo type I-I on the middle shelf 


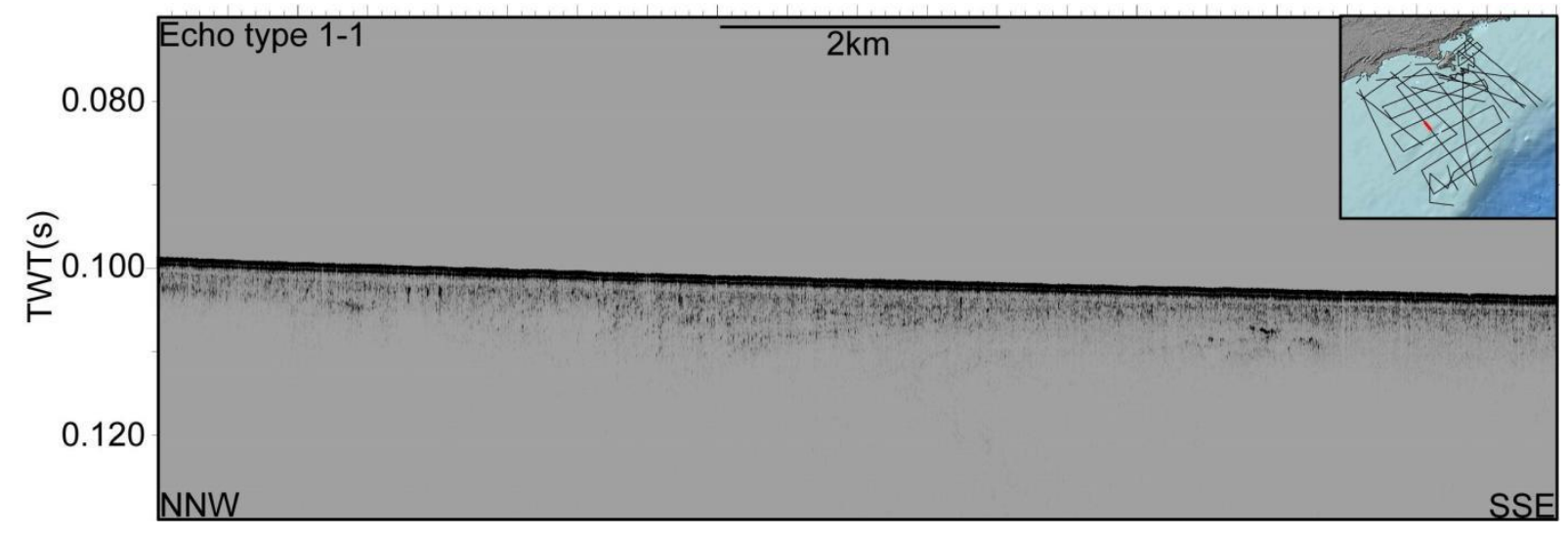

Figure I2. Echo type I-I on the middle shelf

\section{I.I.2. Type I-2. Flat sea floor with medium to high-amplitude sub- bottom reflectors}

The I-2 echo type (Figures I 3 to I5) presents a flat and sharp to semi-prolonged bottom echo with medium to high-amplitude internal reflectors. It shows higher acoustic penetration (8 to 25 meters thick) than echo $\mathrm{I}-\mathrm{I}$. There is considerable variability of internal reflectors configurations (e.g., parallel, inclined, channel-shaped) and signatures of individual reflectors regarding amplitude and lateral continuity. This echo type is found on the middle shelf, but also in some confined proximal and distal areas, such as the shelf adjacent to São Sebastião Island, and the southwestern part of the outer shelf. This type accounts for $24.3 \%$ of the echoes found on the shelf (764 linear kilometers).

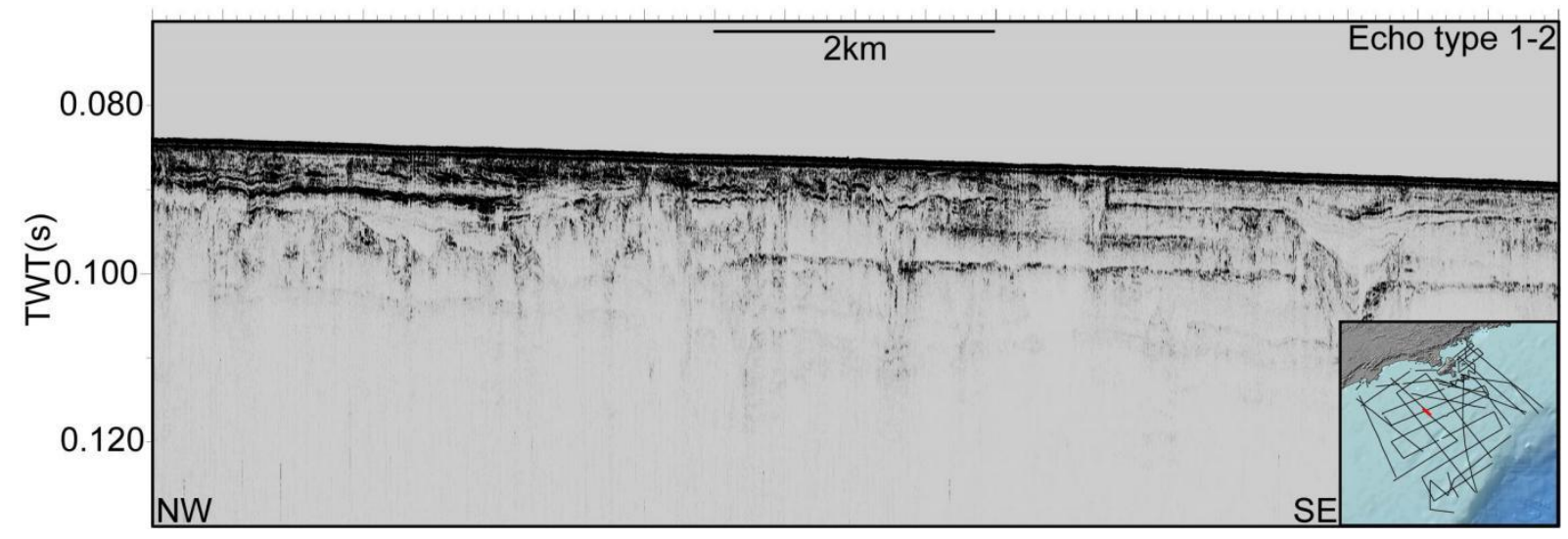

Figure 13. Echo type I-2 on the middle shelf perpendicular to the coast 


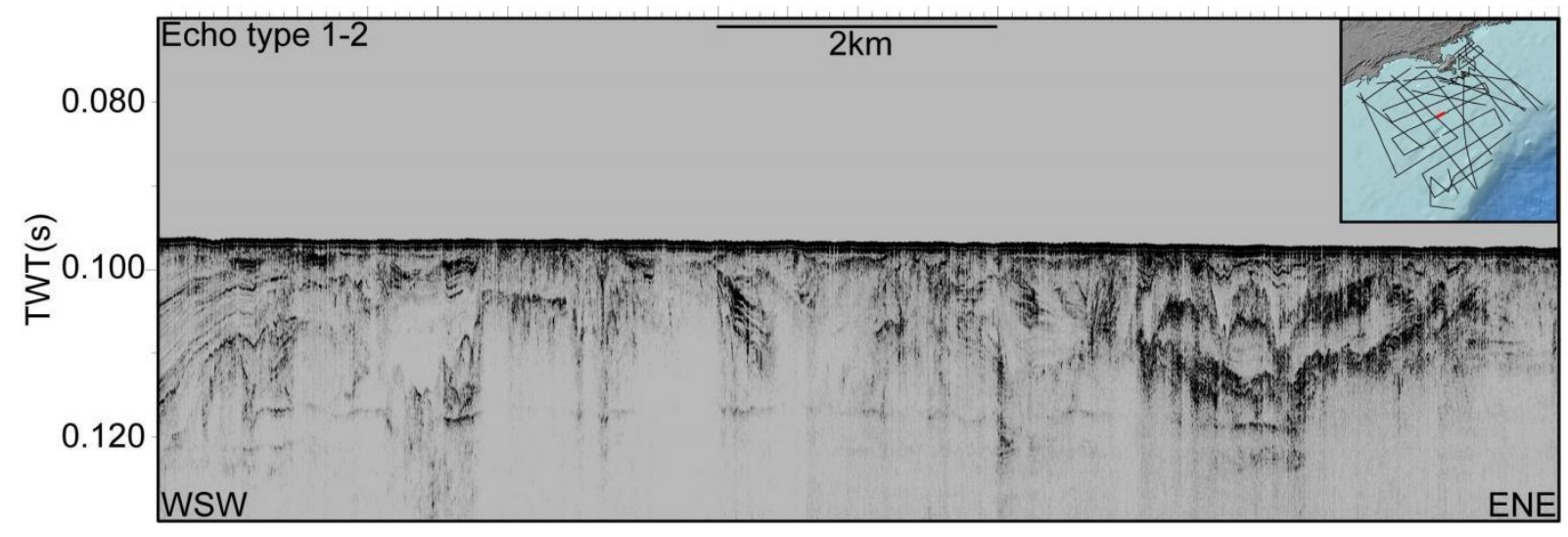

Figure 14. Echo type I-2 on the middle shelf parallel to the coast

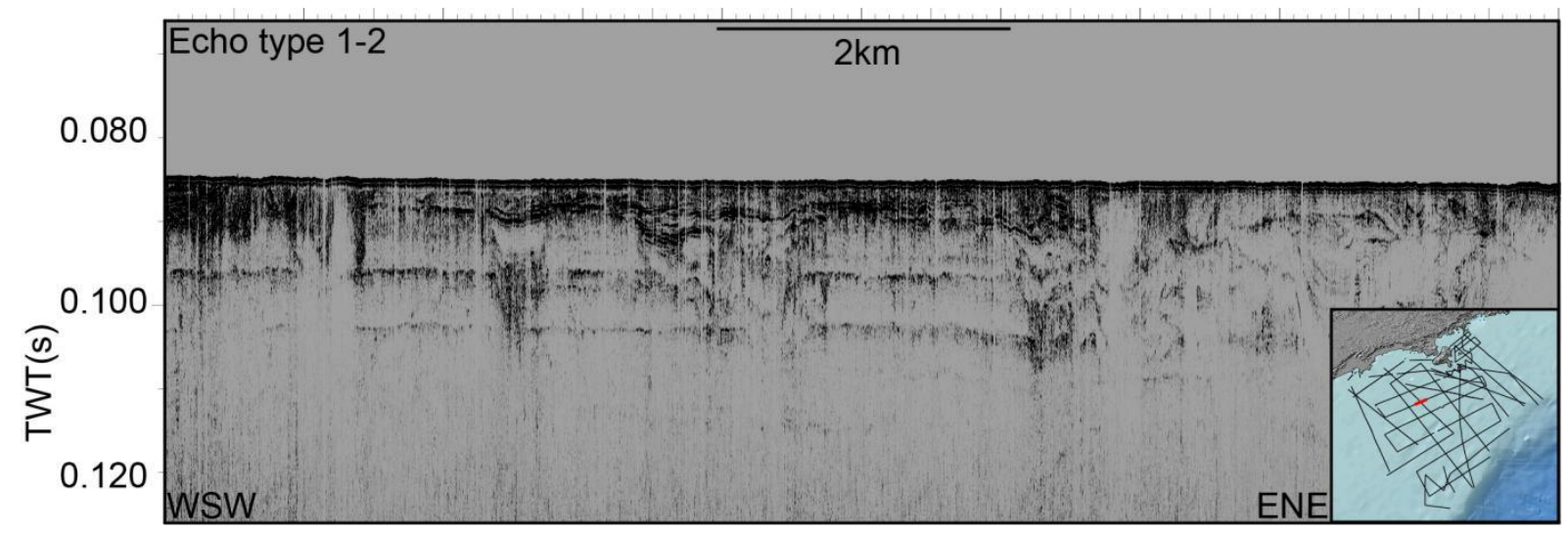

Figure I5. Echo type I-2 on the middle shelf parallel to the coast

\section{I.I.3. Type I-3. Transparent superficial layer followed by high reflective reflectors}

Echo I-3 (Figures 16 to 18) is characterized by a flat and sharp bottom echo with no or some low amplitude sub-surface reflectors. The thickness of the acoustic response reaches up to 18 meters, and locally it shows low amplitude internal reflectors. The transparent acoustic response is substituted at depth by relatively high amplitude reflectors, which probably correspond to echo I-2. Echo I-3 occurs mainly on the inner shelf and southwest of the outer shelf. This echo character is the most widely distributed on the shelf, occupying $39.4 \%$ of the surveyed area (I 242 linear kilometers). 


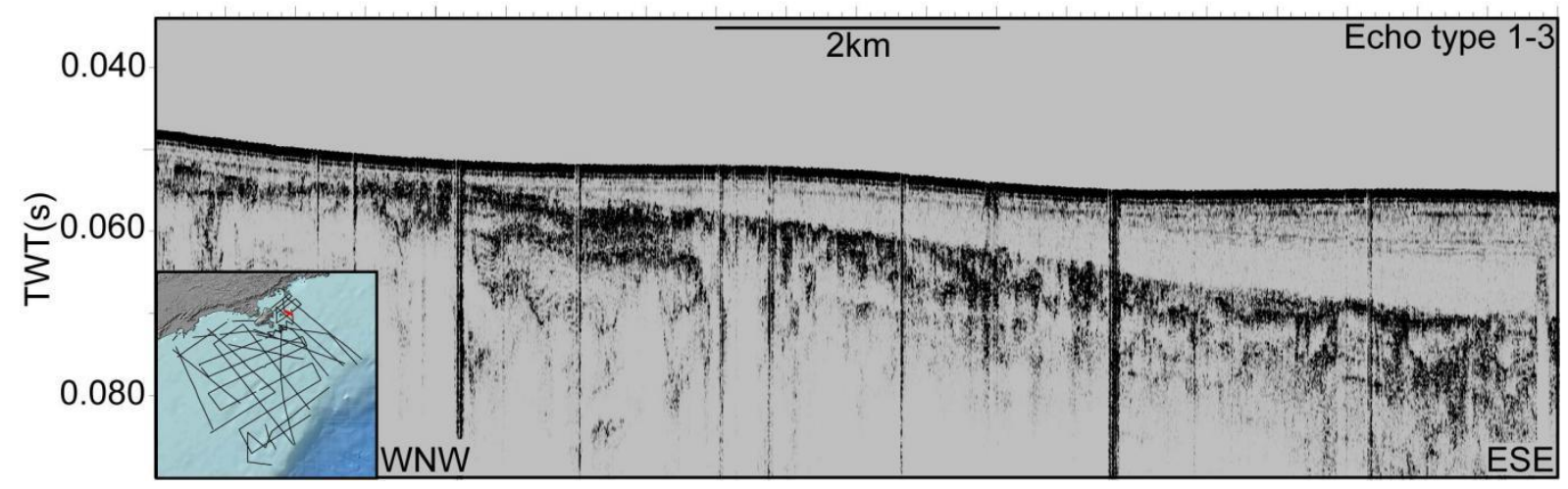

Figure 16. Echo type I-3 with low-amplitude internal reflector located on inner shelf northeastern off São Sebastião Island

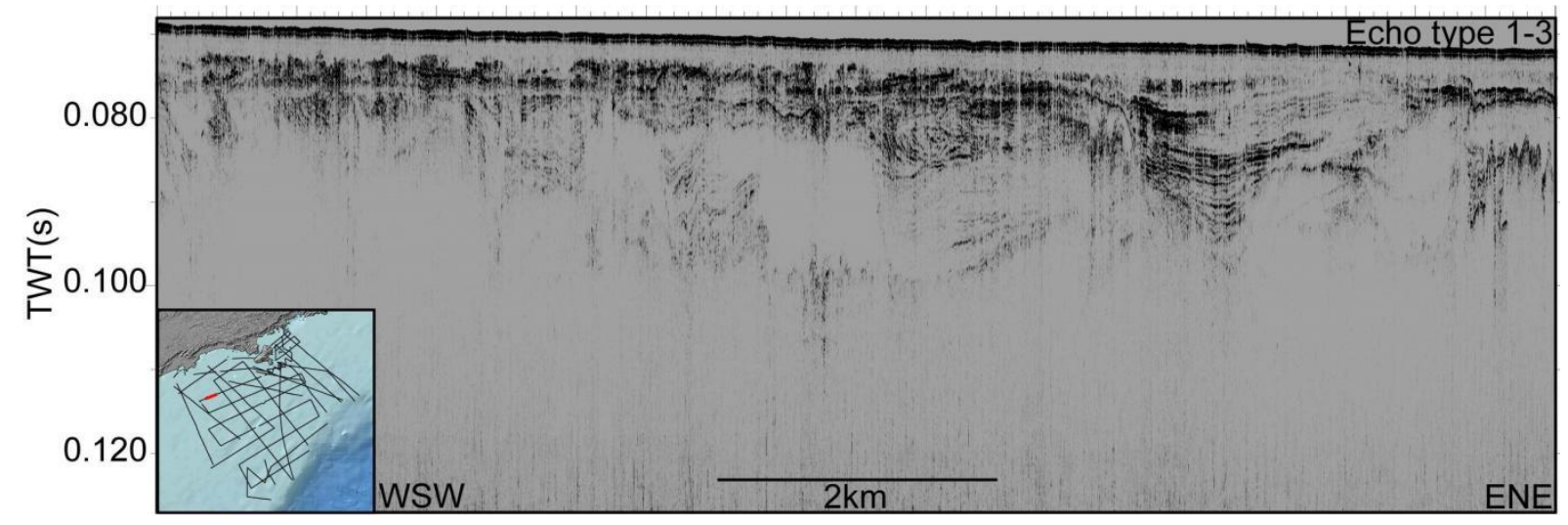

Figure 17. Echo type I-3 located on the southwestern inner shelf

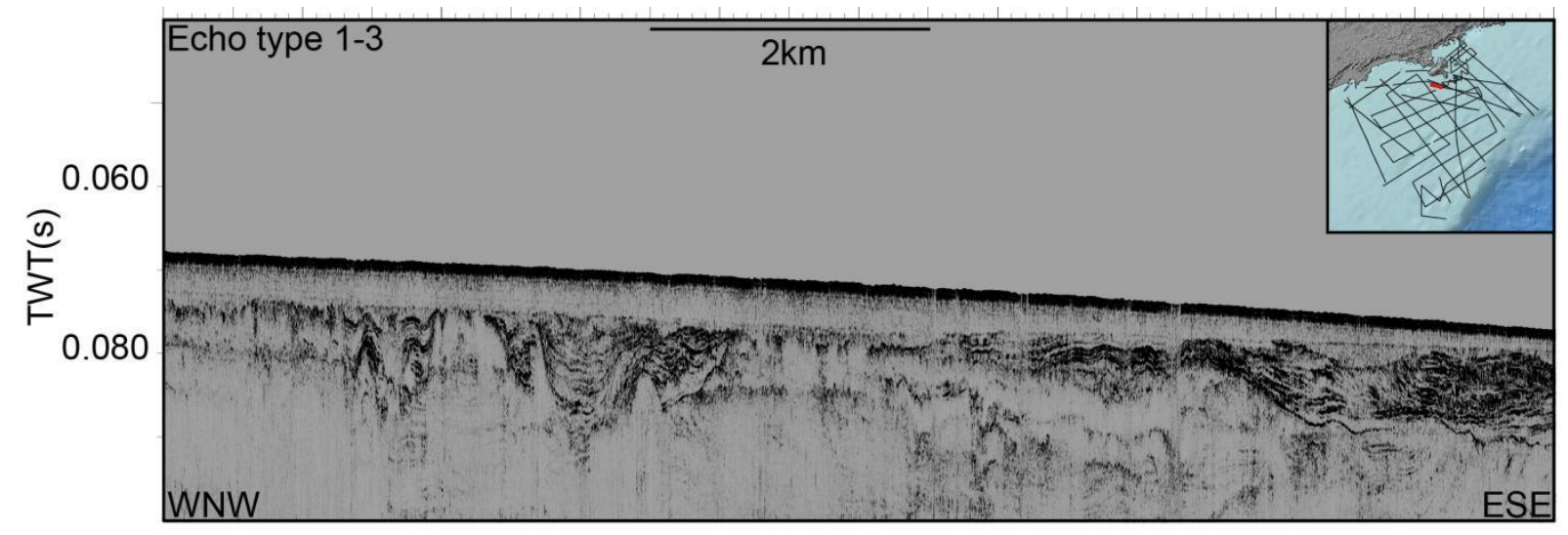

Figure I 8. Echo type I-3 with low amplitude internal reflectors located on the southwestern inner shelf

\section{I.I.4. Type I-4. Flat seafloor covered by regularly spaced seafloor undulations}

Echo I-4 (Figures 19 and 20) is characterized by a flat seafloor (little sloping) molded by undulations that exhibit heights of 2 to 4 meters and wavelengths of 250 meters to one 
kilometer. The bottom echo is semi-prolonged and with no or few subsurface reflectors due to the limitation of signal penetration. This echo occurs mainly on the outer northern shelf, near to echoes $\mathrm{I}-\mathrm{I}$ or $3-2$, occupying $2.0 \%$ of the surveyed area $(64 \mathrm{~km})$.

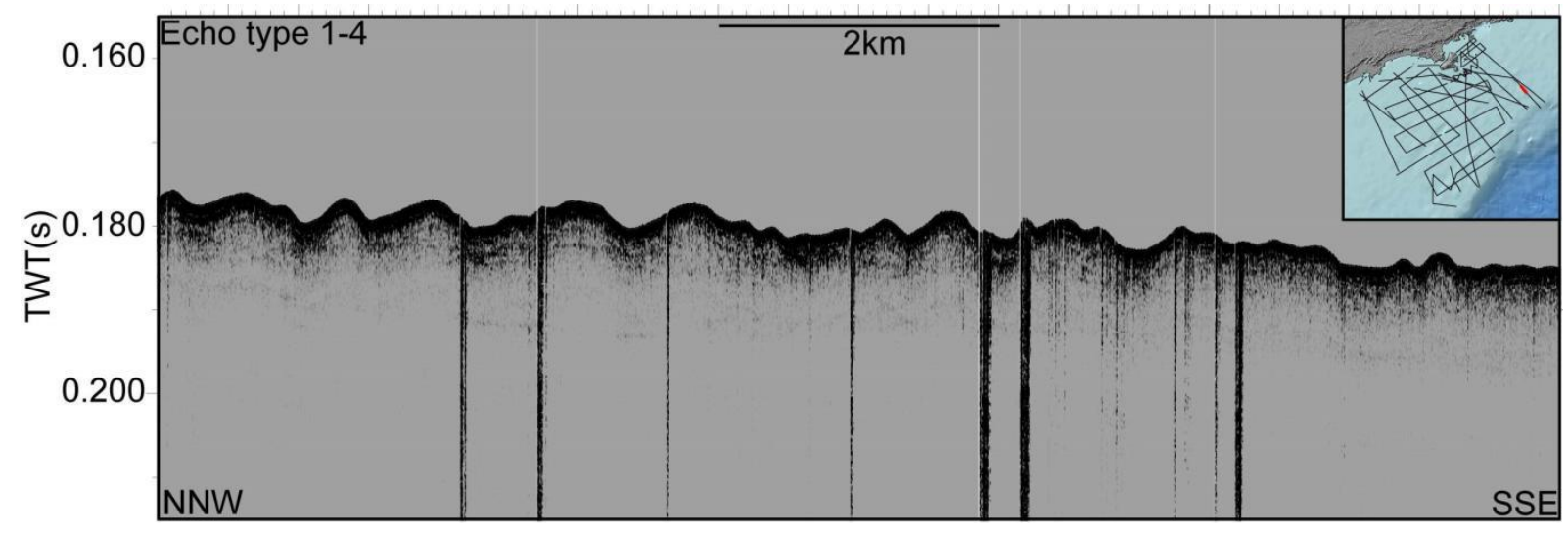

Figure 19. Echo type I-4 found on the northeastern outer shelf

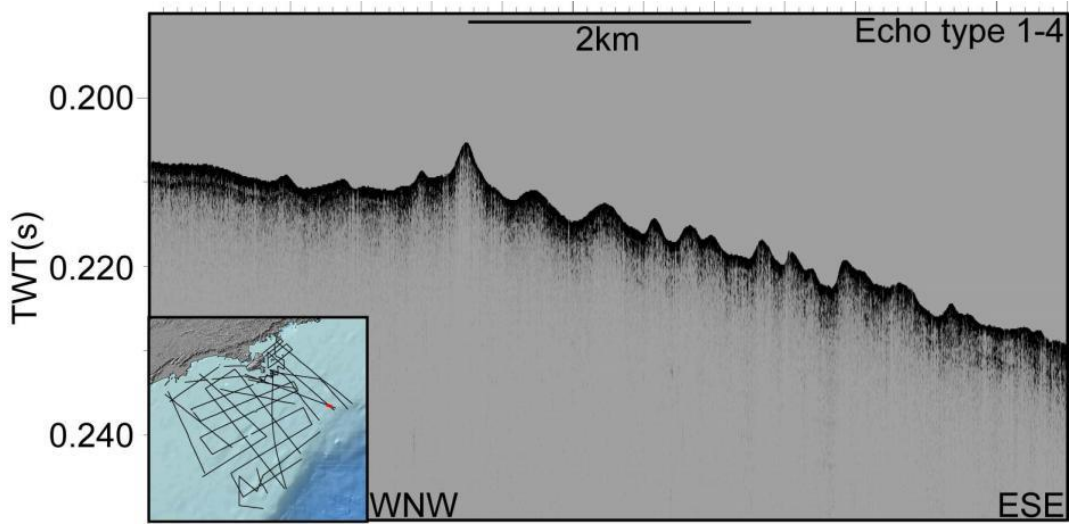

Figure 20. Echo type I-4 next to the shelf break

\section{I.2. Mounded Echoes (Class 2)}

Only one echo type of this class is identified, with no sub-bottom reflectors.

\section{I.2.I. Type 2-I - Mounds with no internal reflectors}

This type of echo (Figures $2 \mathrm{I}$ and 22) consists of a succession of mounds that reaches up to 13 meters height and up to one kilometer long. It differs from echo I-4 by the size of the seafloor mounds and by the absence of a regular frequency. It presents a prolonged bottom echo and low acoustic penetration with no or scarce subsurface echoes. These mounds are symmetric or nearly symmetric and surrounded by I-I and 3-2 echoes. This echo represents 
2.1\% of the total surveyed area, i.e. 65 kilometers, and is restricted to the outer shelf, close to the shelf break.

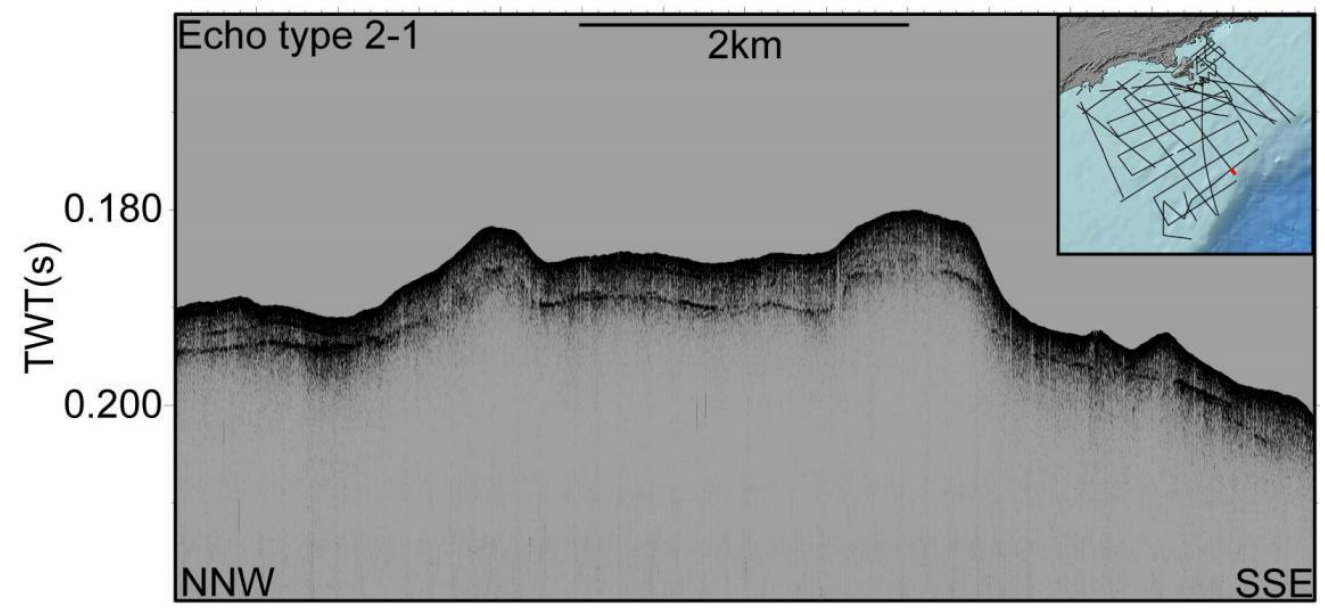

Figure 2I. Echo type 2-I located on the shelf break

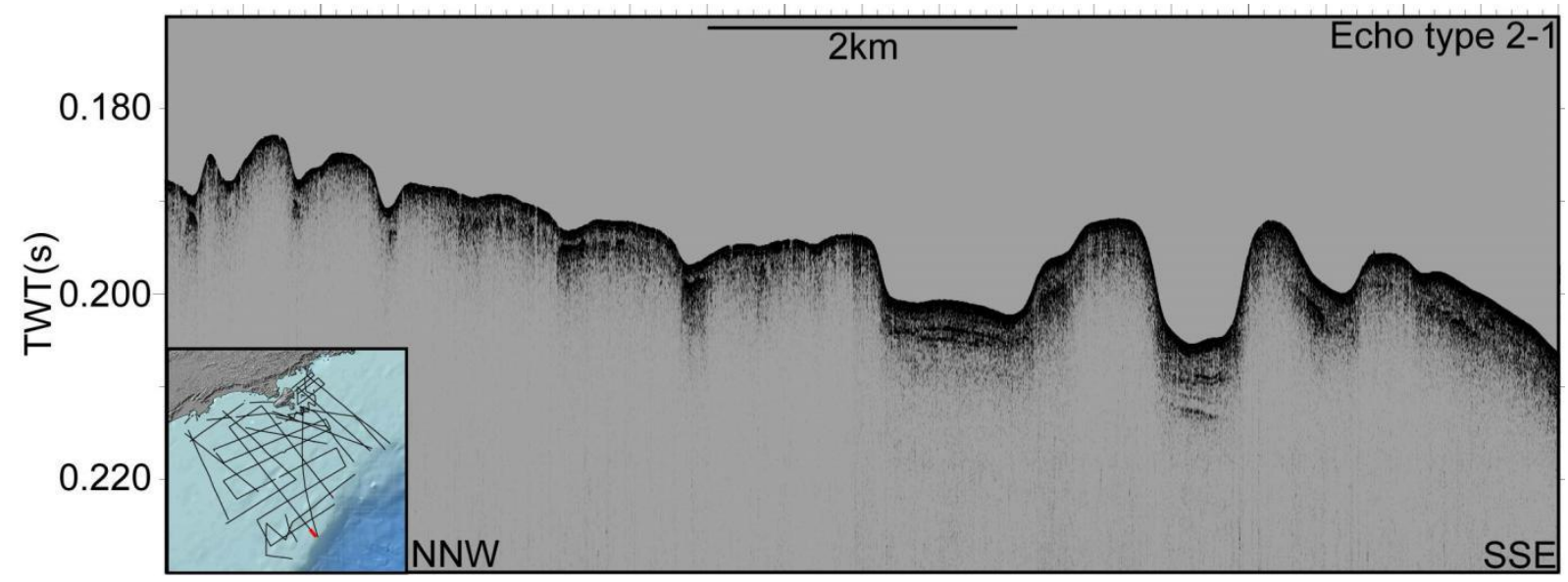

Figure 22. Echo type 2-I located on the shelf break

\section{I.3. Irregular Echoes (Class 3)}

The echoes comprising this class present an irregular seafloor and are classified according to the presence or absence of internal reflectors and the relief variations. This class represents $20.5 \%$ of the total surveyed area.

\section{I.3.I. Type 3-I. Irregular echo with prolonged internal reflectors}

Echo 3-I (Figures 23 and 24) represents an irregular, sharp to prolonged bottom echo with high signal penetration and highly variable and irregular sub-bottom reflectors. It is similar 
to echo I-2, but with an irregular seafloor. This echo presents as asymmetric structures on the seafloor that reach up to 4 meters height, and which cover a few kilometers in length, but usually less than $10 \mathrm{~km}$. This echo is surrounded by flat echoes such as I-2 and I-3. It represents $2.3 \%$ of the surveyed area with 72 kilometers.

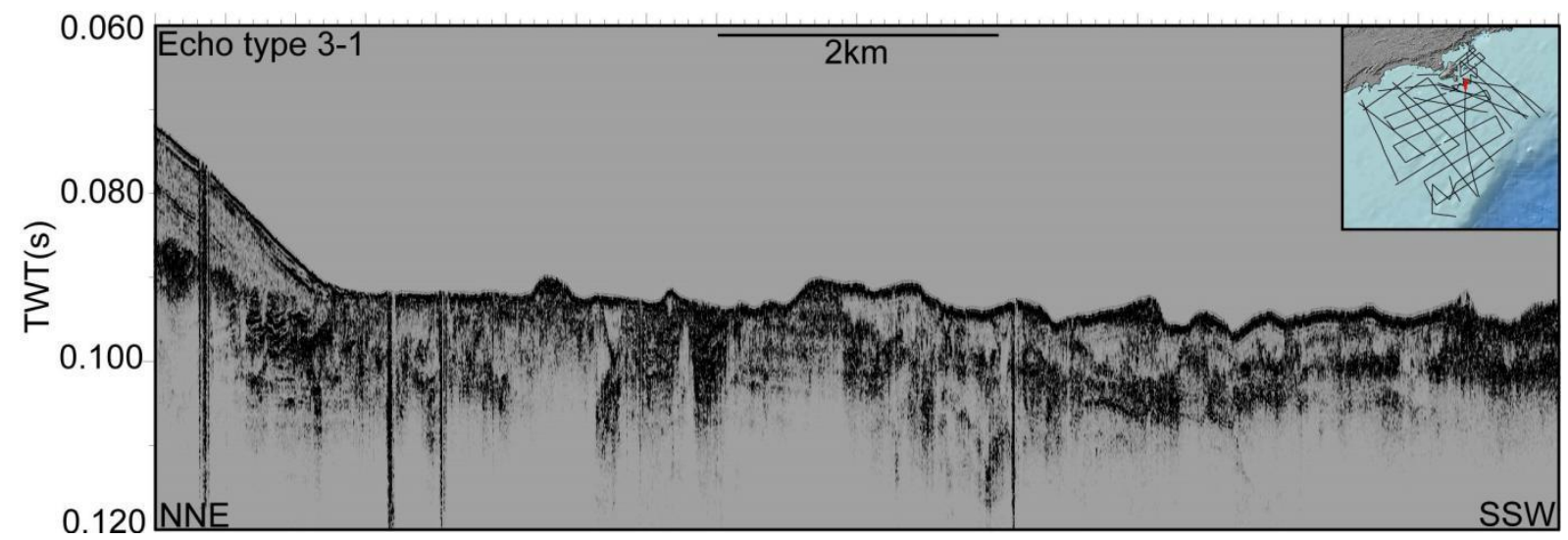

Figure 23. Echo type 3-I located southeastern off São Sebastião Island

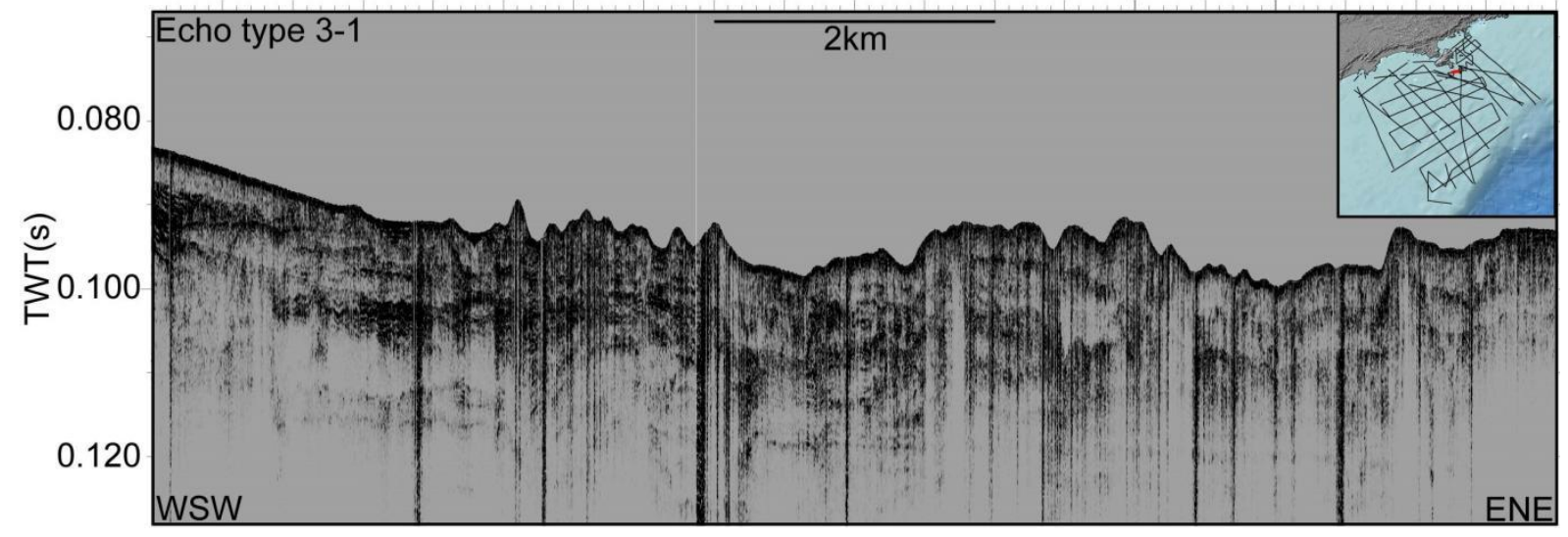

Figure 24. Echo type 3-I located southeastern off São Sebastião Island

\section{I.3.2. Type 3-2 - Broad irregular echo with high relief variations}

This type (Figures 25 to 29) refers to irregular echoes that present high relief variations. The bottom echo is sharp to prolonged, and sub-bottom echoes are relatively poorly developed. This echo character mainly occupies the middle to outer shelf and is observed along 574 kilometers, $18.2 \%$ of the surveyed area. 


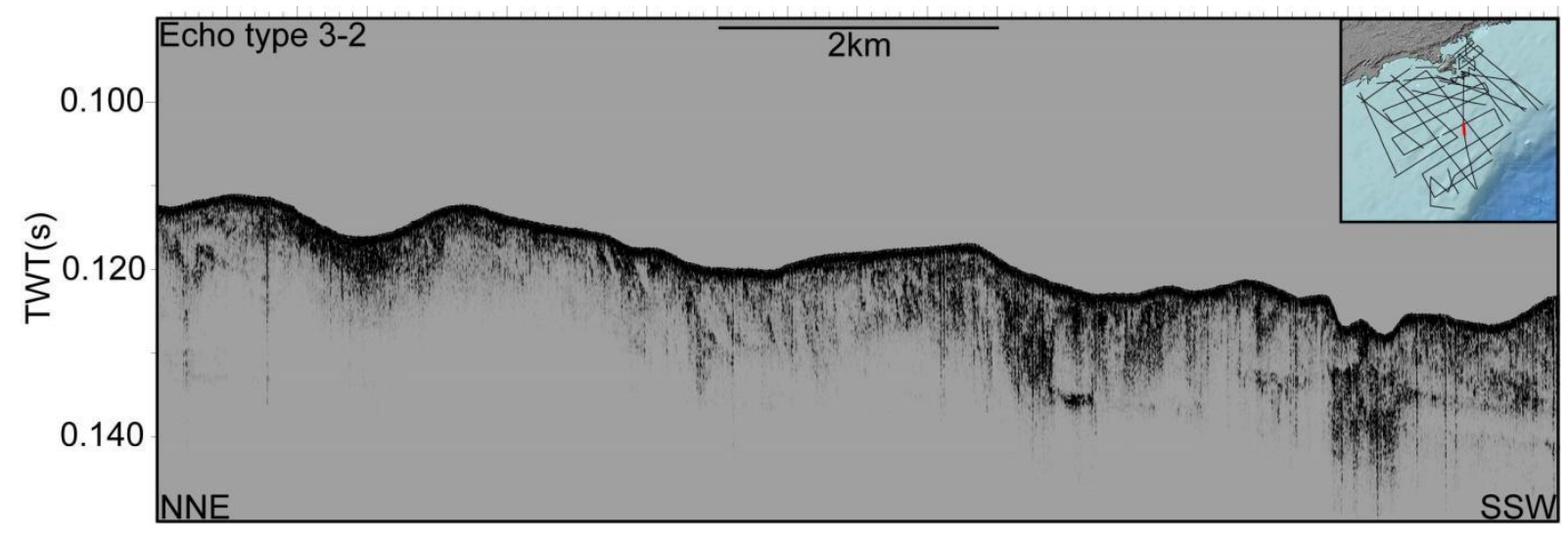

Figure 25. Echo type 3-2 located on the outer shelf

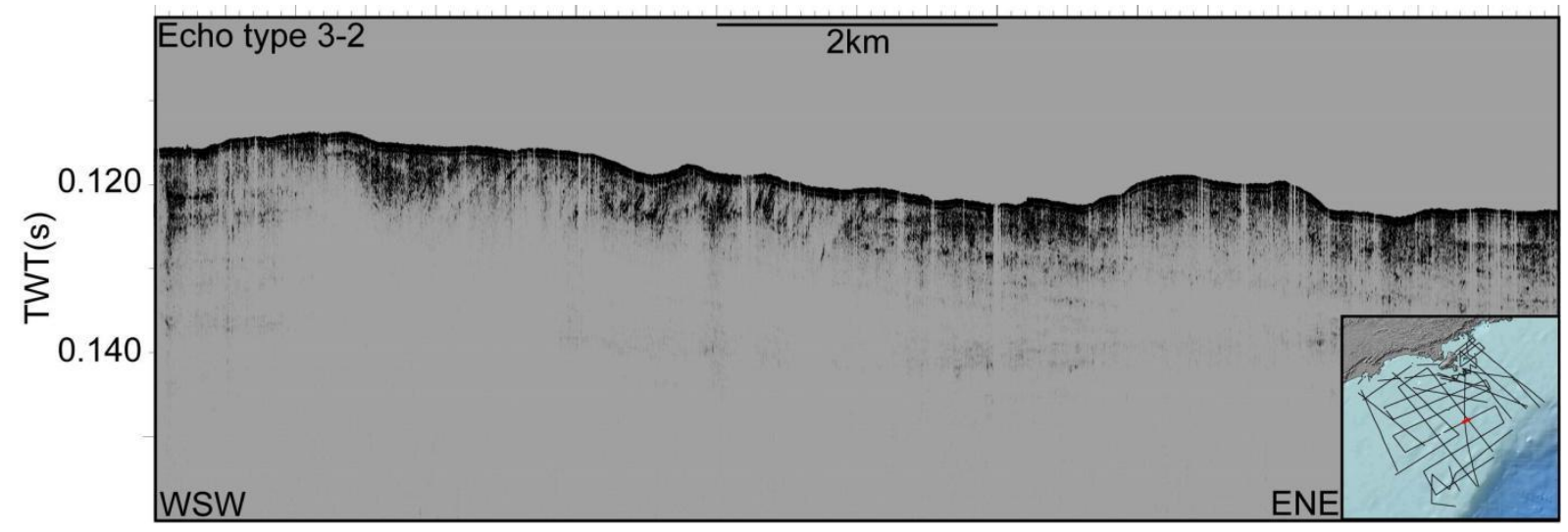

Figure 26. Echo type 3-2 located on the outer shelf

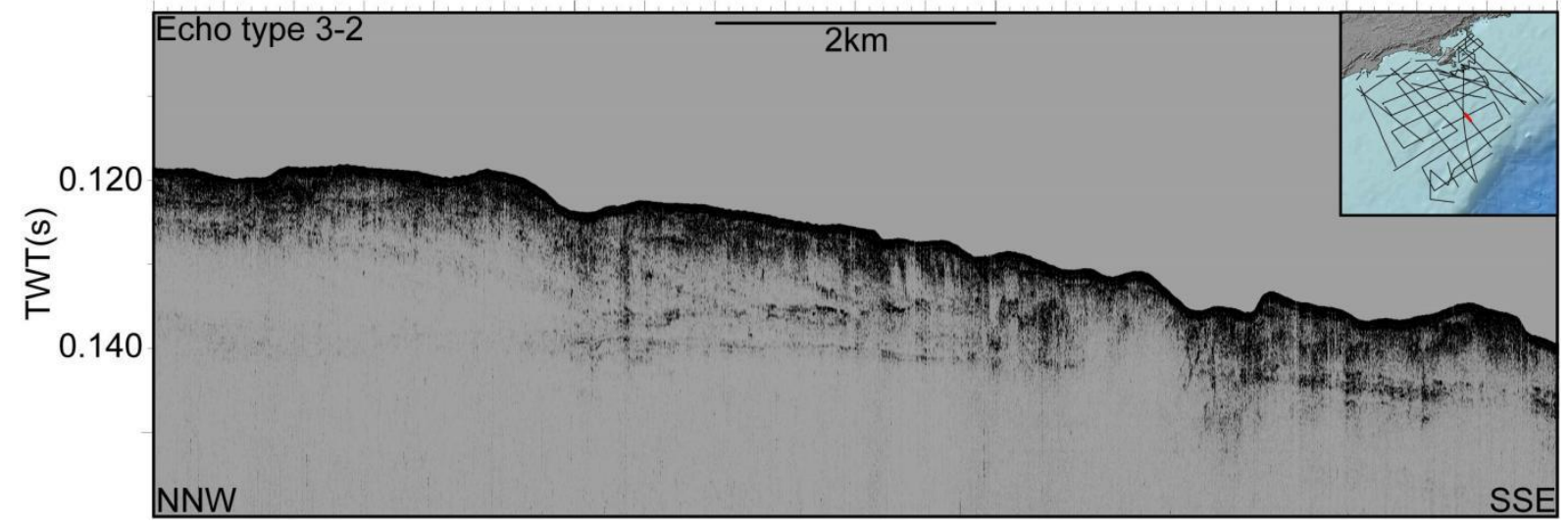

Figure 27. Echo type 3-2 on the outer shelf perpendicular to the coast 


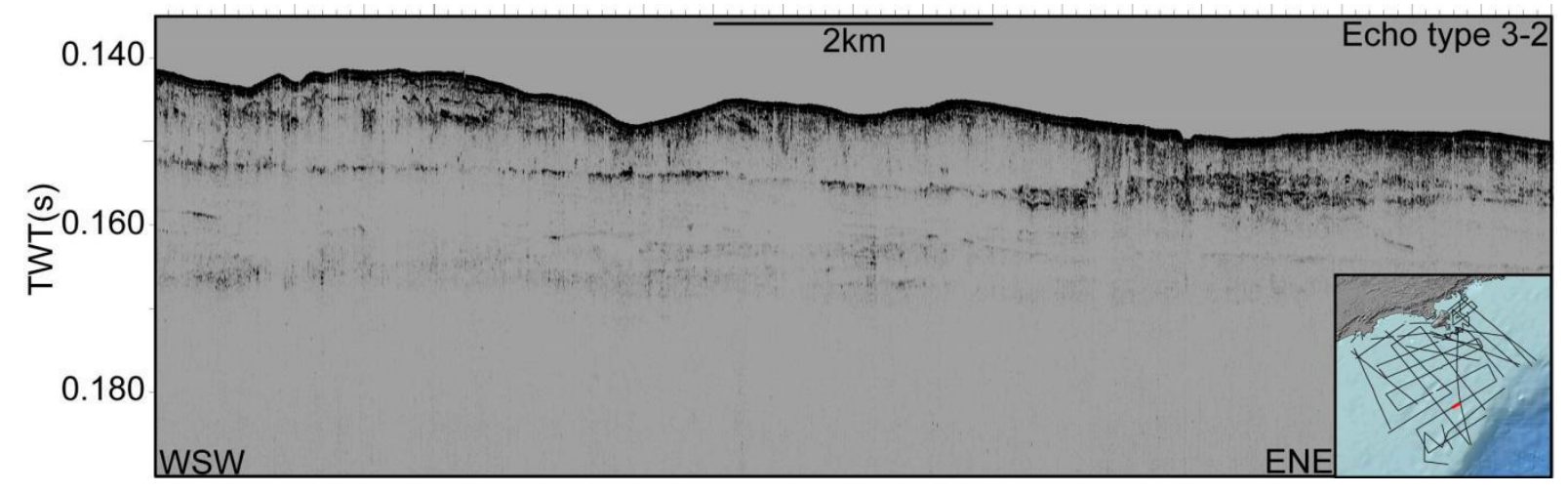

Figure 28. Echo type 3-2 with a flat sub-bottom reflector located on the southwestern outer shelf

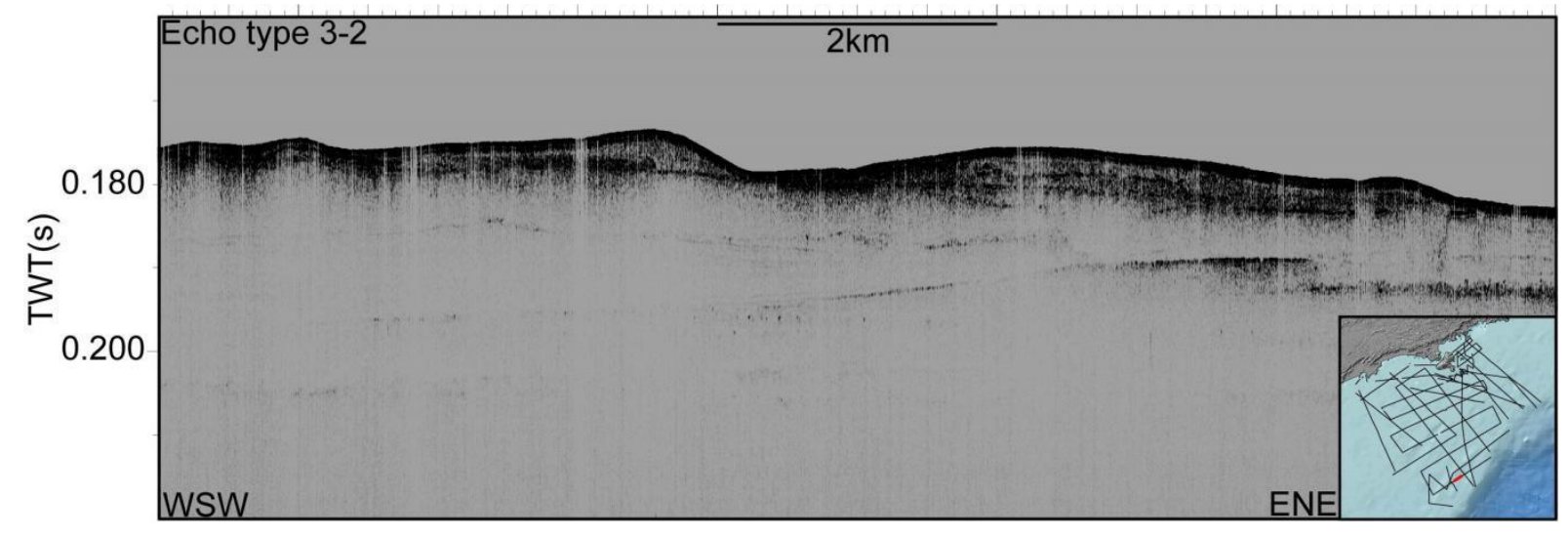

Figure 29. Echo type 3-2 on the southwestern outer shelf

\subsection{Sedimentological Analysis}

\subsection{Mud Content}

Mud contents are highly variable along the continental shelf, as values ranged from 0 to $78 \%$ (Figure 30). Overall, the continental shelf exhibits low contents of mud (up to $20 \%$ ). However, three areas with relatively higher mud contents are observed: northeastern of the São Sebastião Island, the northeastern outer shelf, and the southwestern outer shelf.

High amounts of mud mark the region around the São Sebastião Island towards the continental shelf. Mud contents may reach up to $60 \%$ of the total sediment in the vicinity of the island. Towards the northeast, a tongue of 20 to $40 \%$ of mud content extends on the inner shelf for around 60 kilometers. 
An elongated package of high mud content occurs in the northeastern outer shelf, parallel to the coast. This package is located from 100 meters depth down to the shelf break and presents mud contents from 20 to $60 \%$ of the total sediment.

The more extensive muddy area is located parallel to the coast on the southwestern outer shelf and it presents mud contents up to $78 \%$. This packet is approximately $80 \mathrm{~km}$ long and $40 \mathrm{~km}$ wide and it extends towards the southwest.

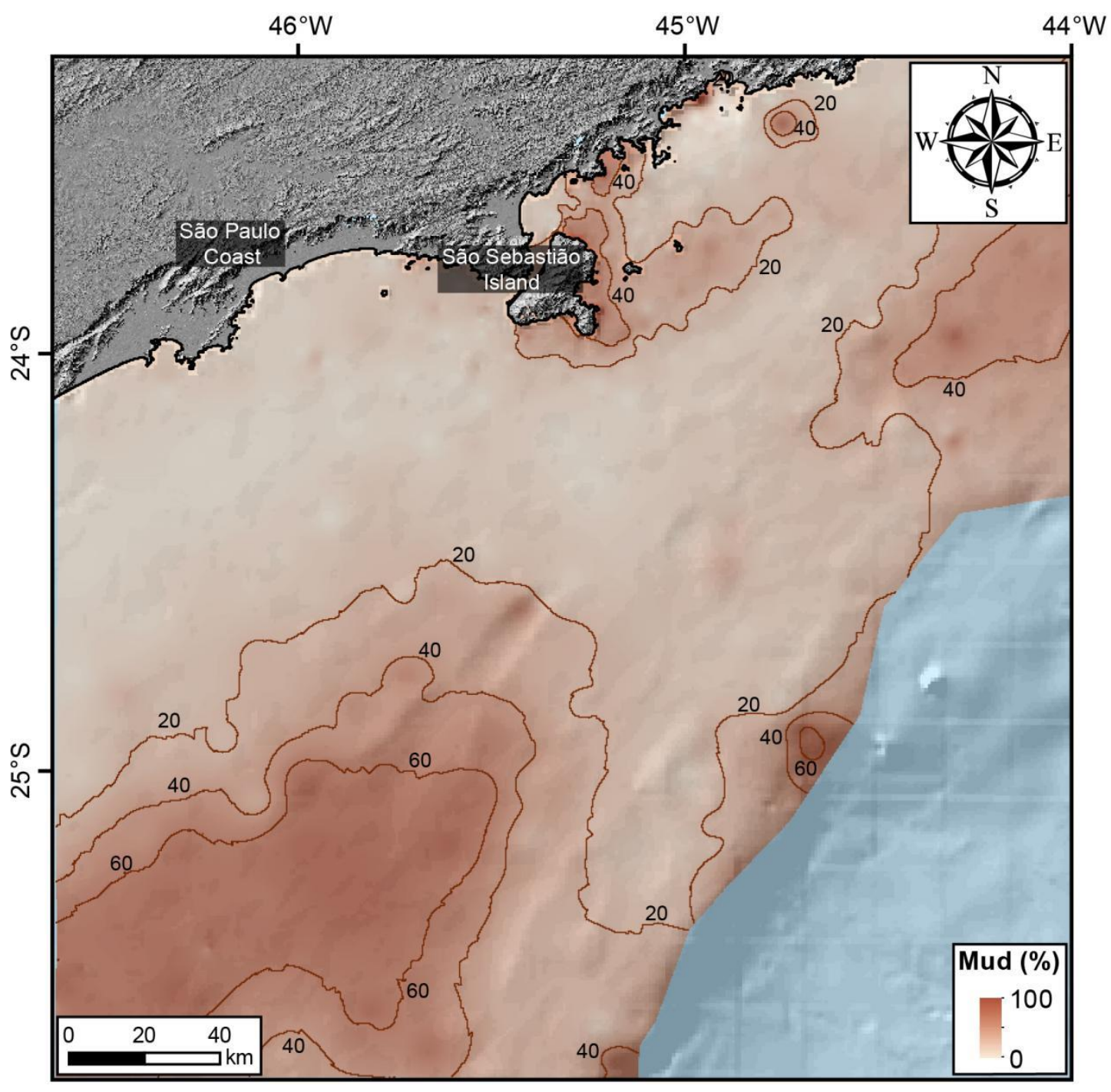

Figure 30. Mud content on the São Paulo Shelf. Relatively stronger colors represent relatively higher values of mud percentage in the surficial sediment

\subsubsection{Calcium Carbonate Content}

The distribution of calcium carbonate content also exhibits a high spatial variability, with a range of values from 0 to $94 \%$ (Figure 31 ). In general, higher contents are located on the 
outer shelf and some parts of the middle shelf off the São Sebastião Island. Over the outer shelf, areas with high $\mathrm{CaCO}_{3}$ content exhibit elongated patterns paralleling the shelf break. The inner shelf and most of the middle shelf present contents lower than $40 \%$.

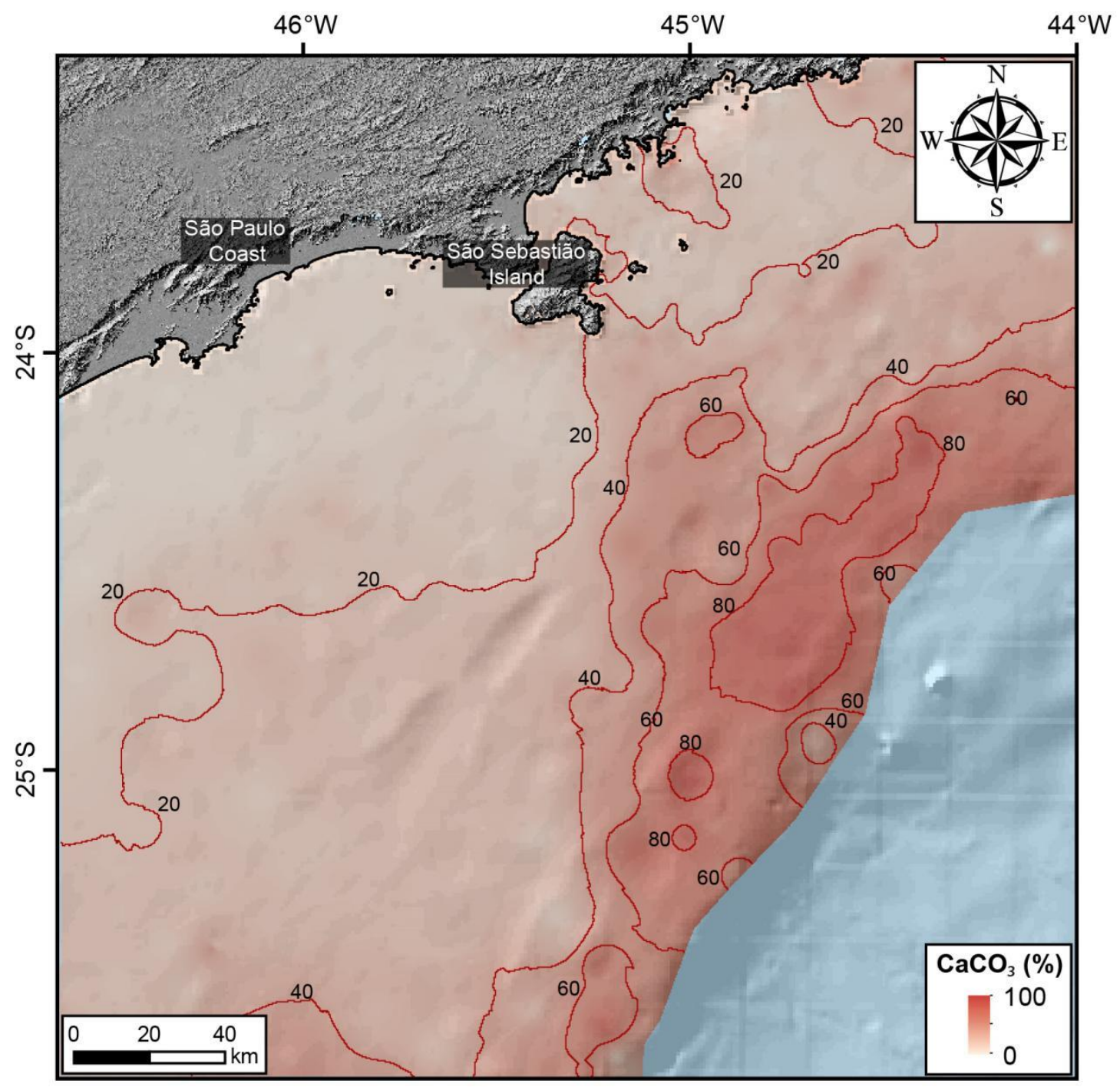

Figure 3 I. Calcium carbonate content on the São Paulo Shelf. Relatively stronger colors represent regions where $\mathrm{CaCO}_{3}$ content is relatively higher

\subsubsection{Spatial correlation between mud and calcium carbonate contents}

The correlation of the spatial variability of the surface contents of muds and calcium carbonate in the sediments of the sea bottom enabled the distinction of five areas with welldefined values (Figure 32):

- Inner shelf southwestward of São Sebastião Island with mud and $\mathrm{CaCO}_{3}$ contents lower than $20 \%$. This area is presented by the green color; 
- The inner shelf around the São Sebastião Island with 20 to $60 \%$ of mud content and less than $40 \%$ of $\mathrm{CaCO}_{3}$. It is mainly located to the northeast off São Sebastião Island and it is represented by the blue color;

- Southwestern middle and outer shelf with mud content higher than $60 \%$ and $\mathrm{CaCO}_{3}$ content lower to $40 \%$ of the total sediment. It is represented by the red color;

- Middle and outer shelf with less than $20 \%$ of mud and more than $40 \%$ of $\mathrm{CaCO}_{3}$ content. This package exhibits an elongated pattern from the central middle shelf towards the southwestern outer shelf. It is the most extensive packet and it is represented by the yellow color;

- Northern outer shelf with medium contents of mud, ranging from 20 to $60 \%$ of the total sediment and more than $40 \%$ of $\mathrm{CaCO}_{3}$ content and it is represented by the purple color.

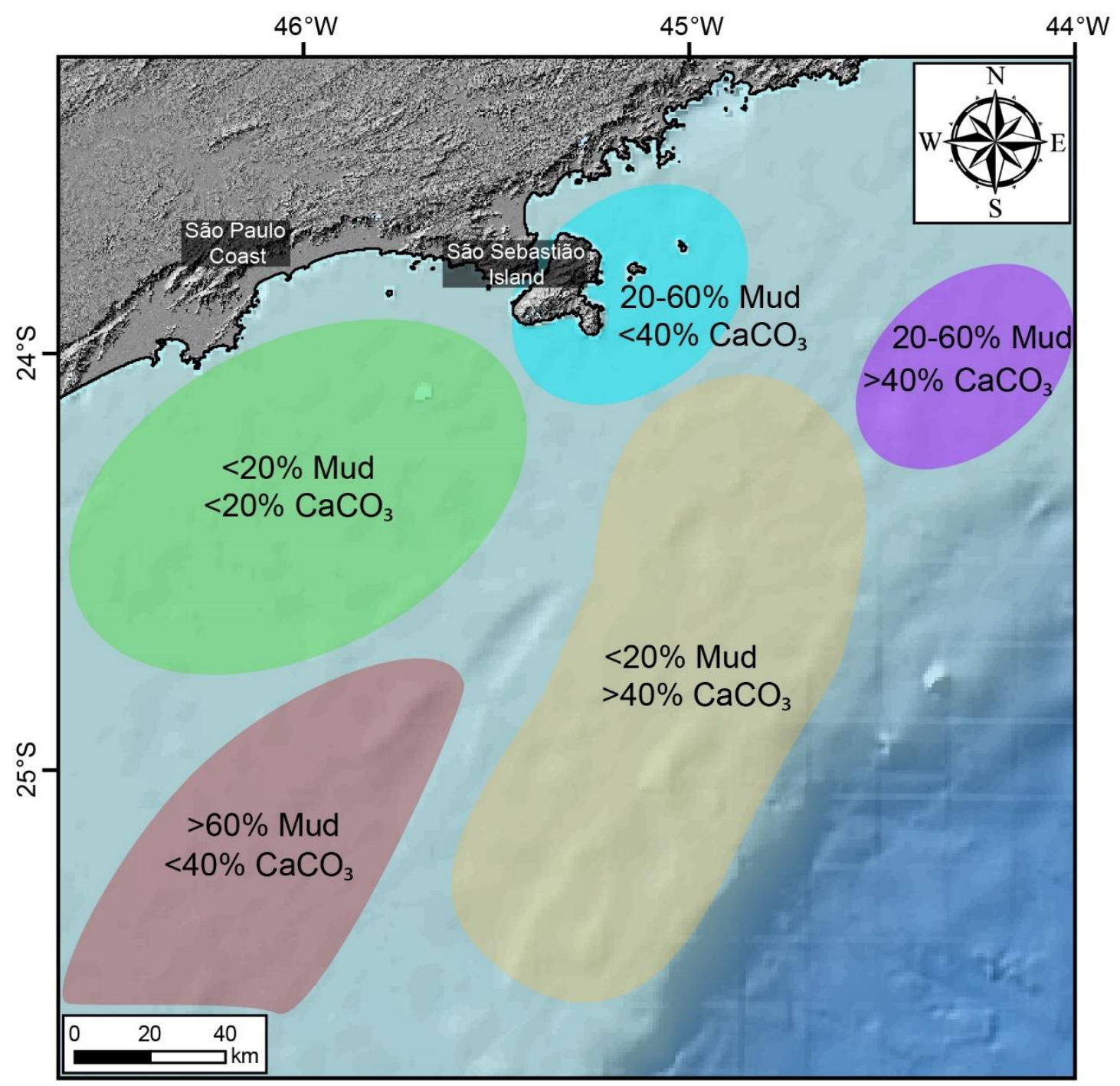

Figure 32. Regions of mud and calcium carbonate contents 


\subsubsection{Spatial correlation between echo types and sedimentological data}

Taking into account the distribution patterns of estimated sedimentological parameters, a map (Figure 33) that illustrates the distribution of each echo type has been built to understand the sedimentation patterns along the shelf. This map shows a high variable acoustic character of the seafloor in the study area: white areas are representative of echo type I-I; purple areas of I-2; deep purple of echoes I-2 and I-3 intercalated; green of I-3; yellow of I-4; orange of 3-I; and red of 3-2. Echo type 2-I is not represented by any specific area in the map, but only some lines inside larger distribution areas.

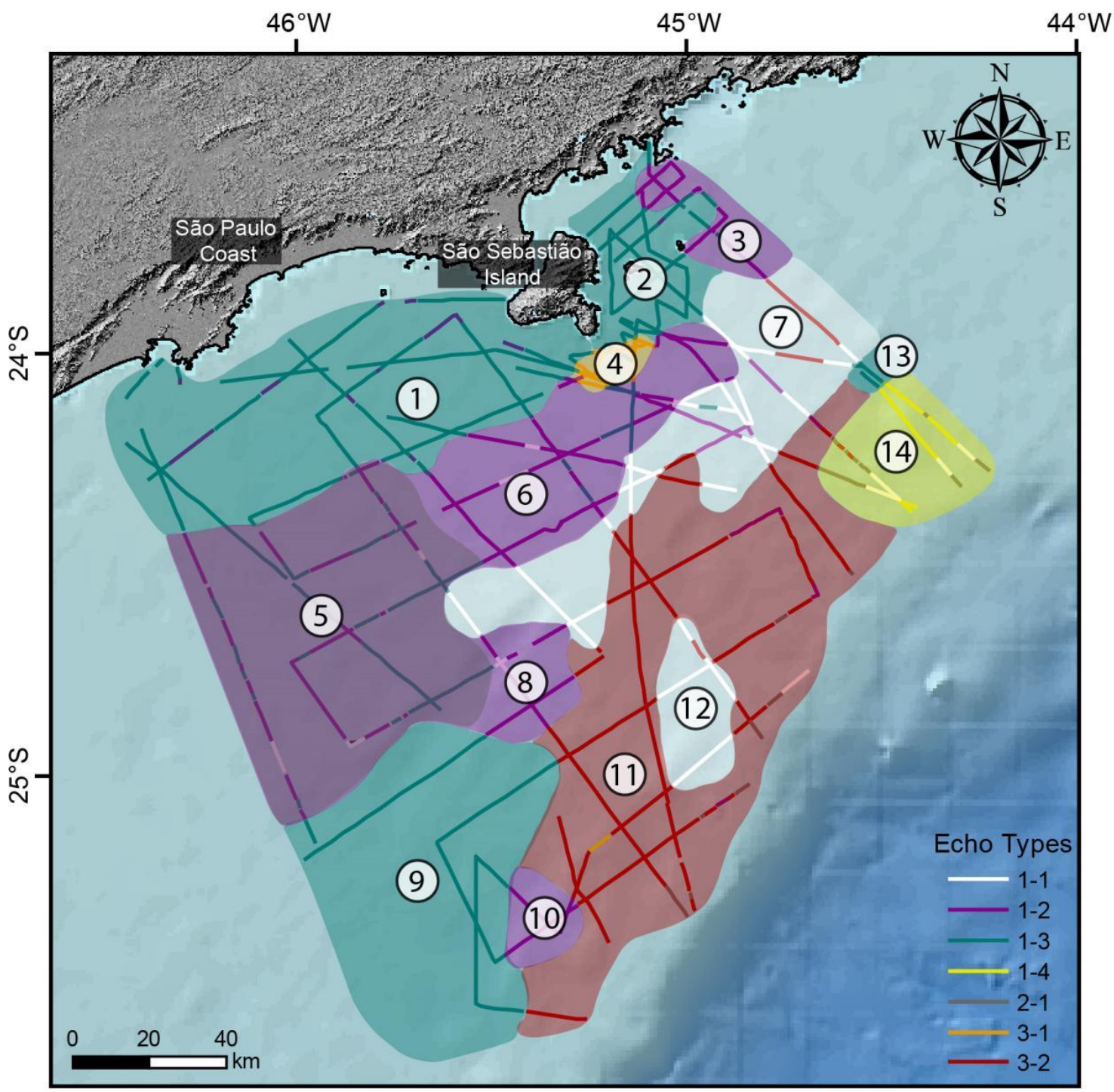

Figure 33. Distribution Map of echo types. Each number indicates a different environment in terms of sedimentological facies and echo characters 
A total of I4 areas with different sedimentological and seismic echo facies have been defined. These environments are described according to their location on the shelf, total extension, and mud and $\mathrm{CaCO}_{3}$ contents.

\subsubsection{Area I (echo type I-3)}

This area is about $4,000 \mathrm{~km}^{2}$ in extent and it is located on the inner shelf southwest of SSI from 20 to 50 meters water depth. This area is dominated by I-3 echo type. The transparent surficial echo ranges from 2 to 5 meters and the penetration reaches up to 22 meters below the seabottom. Most of the area exhibits low amplitude parallel sub-surface reflectors. Various highly reflective channel-like reflectors are observed below the transparent echo. This area presents mud and $\mathrm{CaCO}_{3}$ contents lower than $20 \%$ of the total sediment.

\subsubsection{Area 2 (echo type I-3)}

This area extends for about $1,200 \mathrm{~km}^{2}$ and it is located on the inner shelf east of the SSI from 20 to 50 meters water depth. This area is also dominated by I-3 echo type, but in this case the surficial transparent echo is consistently thicker presenting up to 18 meters.

Low amplitude parallel sub-bottom reflectors are observed to the southeast of SSI, while to the northeast sub-bottom reflectors are not identified. In a few seismic profiles in this area, a lack of signal penetration that presents less than one kilometer in length was detected at depth (Figure 34).

This area presents higher amounts of mud (20-60\%) than Area I and less than $20 \%$ of calcium carbonate content.

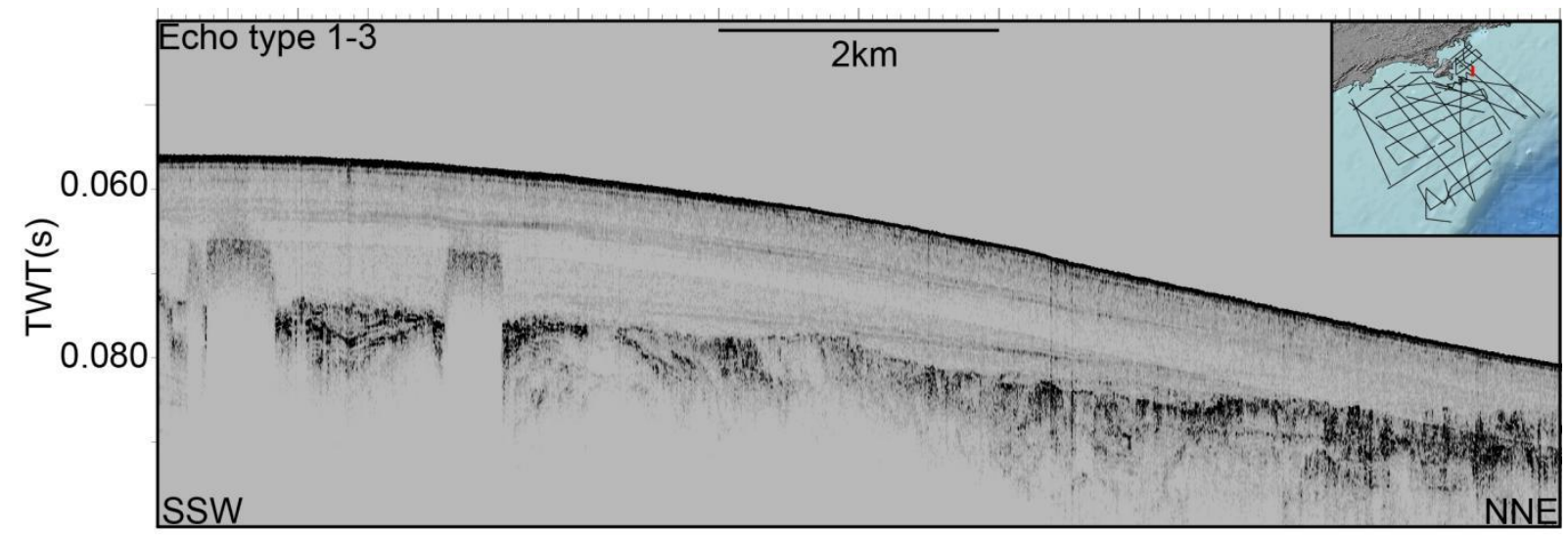


Figure 34. Echo I-3 with lacks of signal penetration representing gas presence

\subsubsection{Area 3 (echo type I-2)}

This area extends for approximately $500 \mathrm{~km}^{2}$ and it is located on the inner shelf east of SSI from 20 to 50 meters water depth. This region is dominated by I-2 echo type and presents less than $20 \%$ of mud content and up to $40 \%$ in $\mathrm{CaCO}_{3}$ content.

\subsubsection{Area 4 (echo type 3-I)}

This area covers approximately $250 \mathrm{~km}^{2}$ and it is located six kilometers to the southeast of SSI around 60 80 meters water depth. This region represents the only occurrence of 3-I echo type on the shelf. It is characterized by low amounts of mud (less than $20 \%)$ and 20 to $40 \%$ of $\mathrm{CaCO}_{3}$ content.

\subsubsection{Area 5 (echo types I-2 and I-3)}

This area covers approximately $4,200 \mathrm{~km}^{2}$ and it is located on the southwestern middle shelf from 50 to 90 meters water depth. It is characterized by the alternation of echoes I-2 and I-3 (Figure 35). Mud constitute up to $60 \%$ of the total sediment, but it usually represent less than $40 \%$. This area is the transition between the low mud content found in the inner shelf and the high mud content of outer shelf. Also, calcium carbonate is less than $40 \%$ of the sediment.

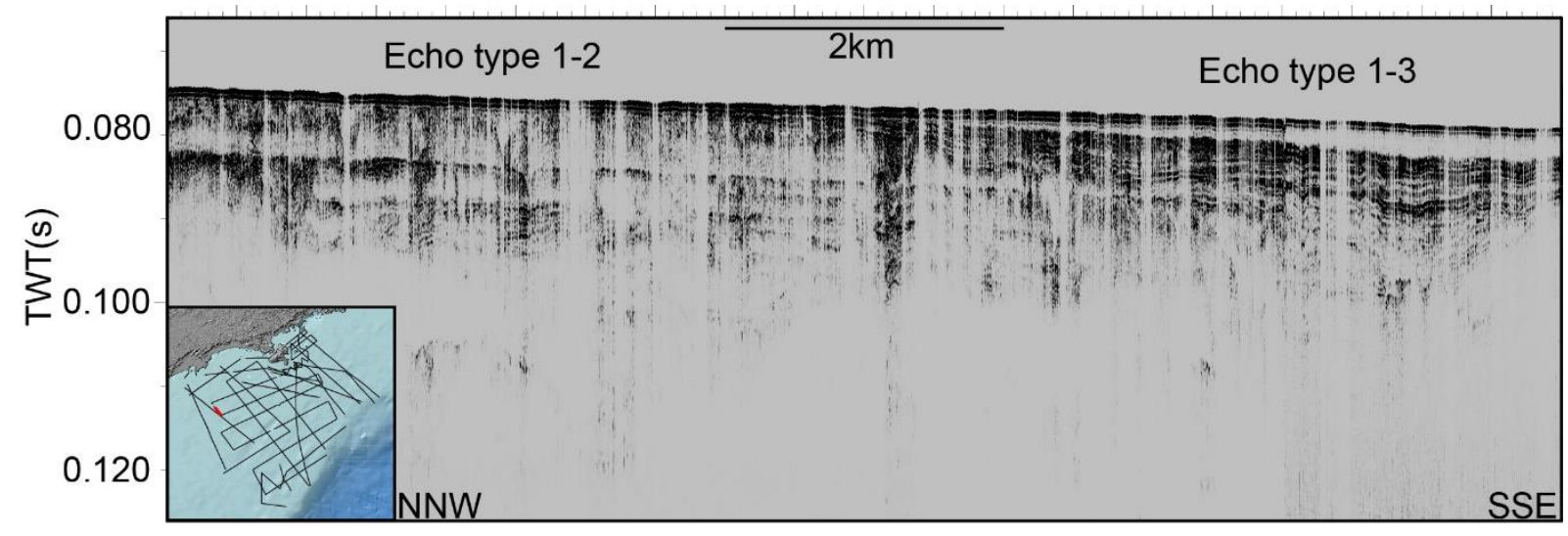

Figure 35. Intercalation of echoes I-2 and I-3 on Area 5 


\subsubsection{Area 6 (echo type I-2)}

This area extends for approximately $2,700 \mathrm{~km}^{2}$ and it is located on the central middle shelf from 50 to 80 meters water depth. This area is dominated by echo I-2, which shows a slightly irregular seafloor towards the northeast. Calcium carbonate content is less than $40 \%$ but exhibits an increasing trend towards the northeast. Mud content in this region is low (less than $20 \%)$.

\subsubsection{Area 7 (echo type I-I)}

This area is $3,600 \mathrm{~km}^{2}$ in extent and covers more than $50 \%$ of the middle shelf from 80 to 100 meters water depth. Similarly to Area 6, a pattern of increasing seafloor irregularities and increasing indistinct (semi-prolonged) bottom echoes is detected towards the northeast. Medium calcium carbonate content (40-60\%) and low mud content (generally less than 40\%) are found in this region.

\subsubsection{Area 8 (echo type I-2)}

This area has approximately $900 \mathrm{~km}^{2}$, and it is located on the central middle shelf from 80 to 100 meters depth. This region is characterized by the presence of $\mathrm{I}-2$ echo type with mud content ranging from 20 to $60 \%$ and $\mathrm{CaCO}_{3}$ content of less than $40 \%$.

\subsubsection{Area 9 (echo type I-3)}

This area extends for approximately $4,800 \mathrm{~km}^{2}$ and it is located on the southwestern outer shelf from 90 to 130 meters water depth. This area is dominated by echo I-3 with a thick superficial transparent echo (up to 9 meters) followed by an alternation of high and low amplitude reflectors (Figure 36). The signal penetration into the sediment is the highest of all surveyed area with a total of 32 meters. This area also presents the highest contents of mud (40 to $78 \%$ ) and less than $40 \%$ of $\mathrm{CaCO}_{3}$. 


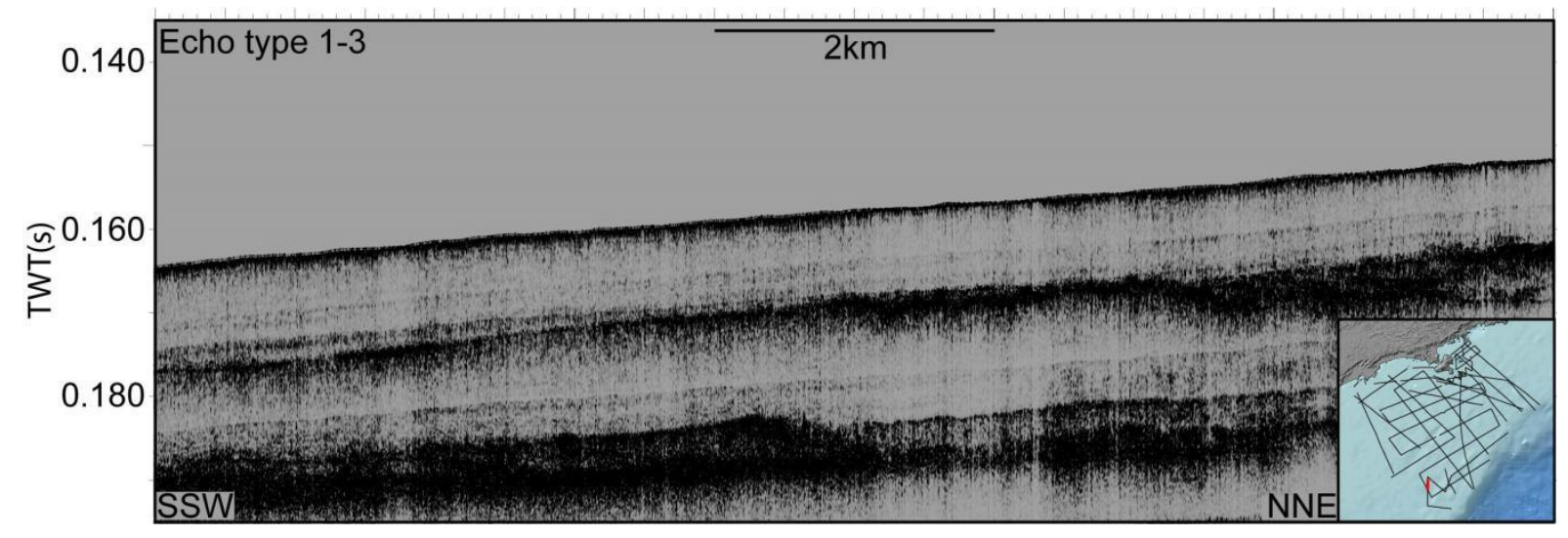

Figure 36. Echo type I-3 located on Area 9

\subsubsection{Area 10 (echo type I-2)}

This area covers approximately $400 \mathrm{~km}^{2}$ and it is located on the southwestern outer shelf from IIO to I30 meters water depth. This region is a topographic high (8 meters in height and 20 kilometers in length) characterized by echo type I-2 with parallel or slightly dipping sub-bottom reflectors. The mud and $\mathrm{CaCO}_{3}$ contents are low (20-40\%).

\subsubsection{I. Area I I (echo type 3-2)}

Area II is the largest area with approximately $7,800 \mathrm{~km}^{2}$ in extent on the outer shelf from 80 to 160 meters water depth. This area is dominated by echo type 3-2, despite the occurrence of isolated patches of echo type I-2 as well. The region is characterized by carbonatic sediments with 40 to $94 \%$ of $\mathrm{CaCO}_{3}$ content and less than $20 \%$ of mud content.

This environment is also characterized by a high morphological variety (e.g. depressions, bathymetric highs, smooth seafloor, rough seafloor, terraced sea floor) and complexity of internal reflectors (e.g. dipping, truncated, parallel, thickening and thinning) (Figures 37 to 41 ). 


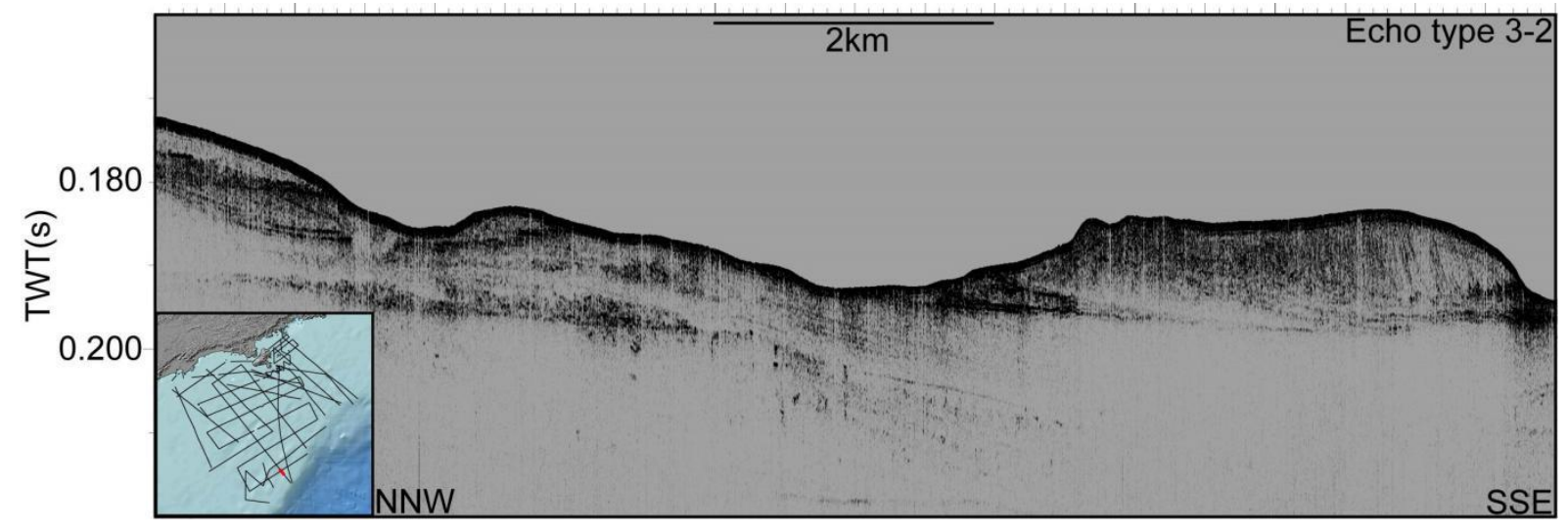

Figure 37. Echo type 3-2 on the southwestern outer shelf with the presence of depressions, smooth surfaces and dipping and truncated internal reflectors

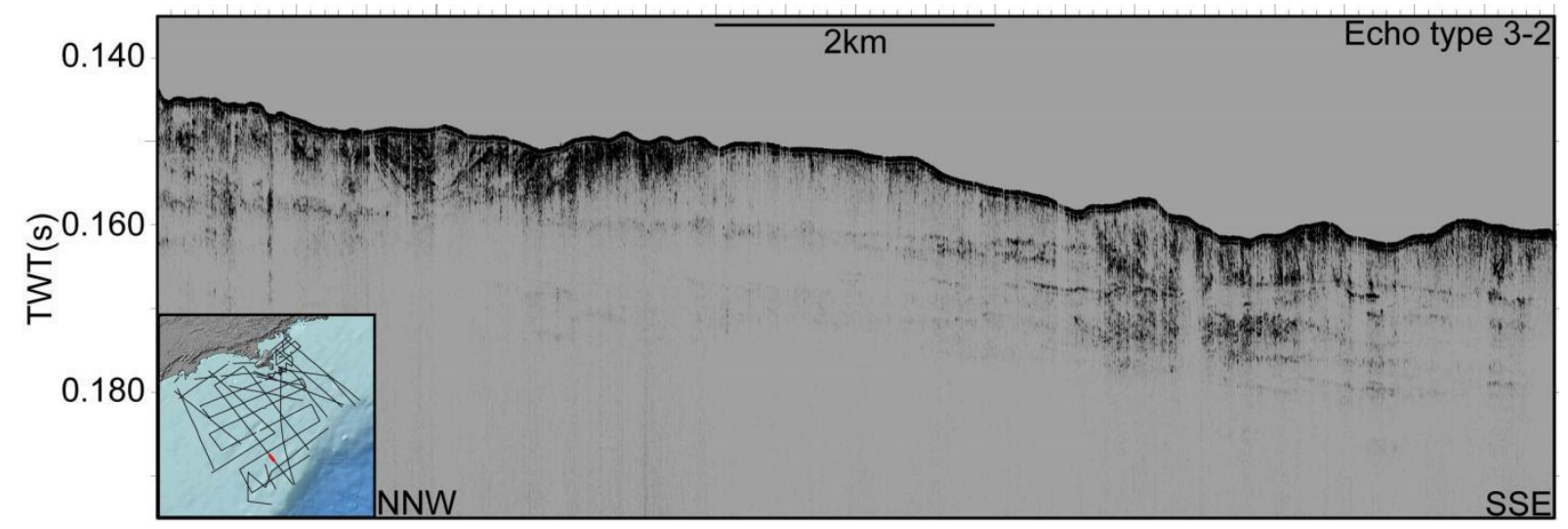

Figure 38. Echo type 3-2 on the southwestern outer shelf with a rough surface

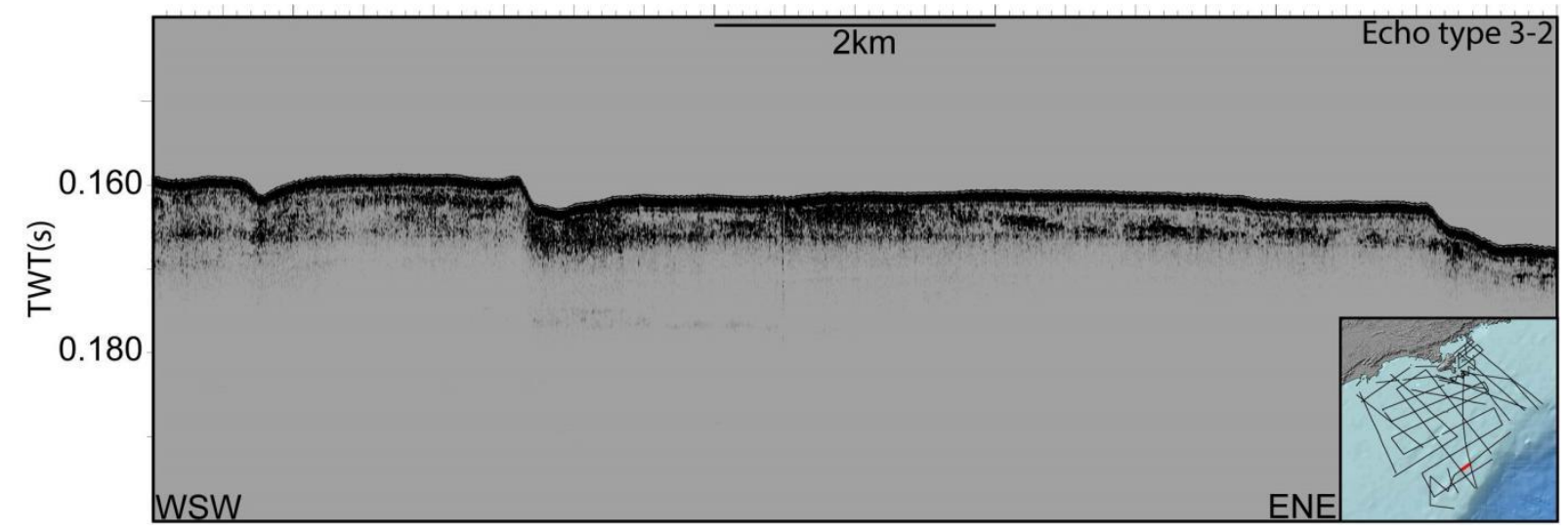

Figure 39. Echo type 3-2 on the outer shelf featuring several seafloor terraces 


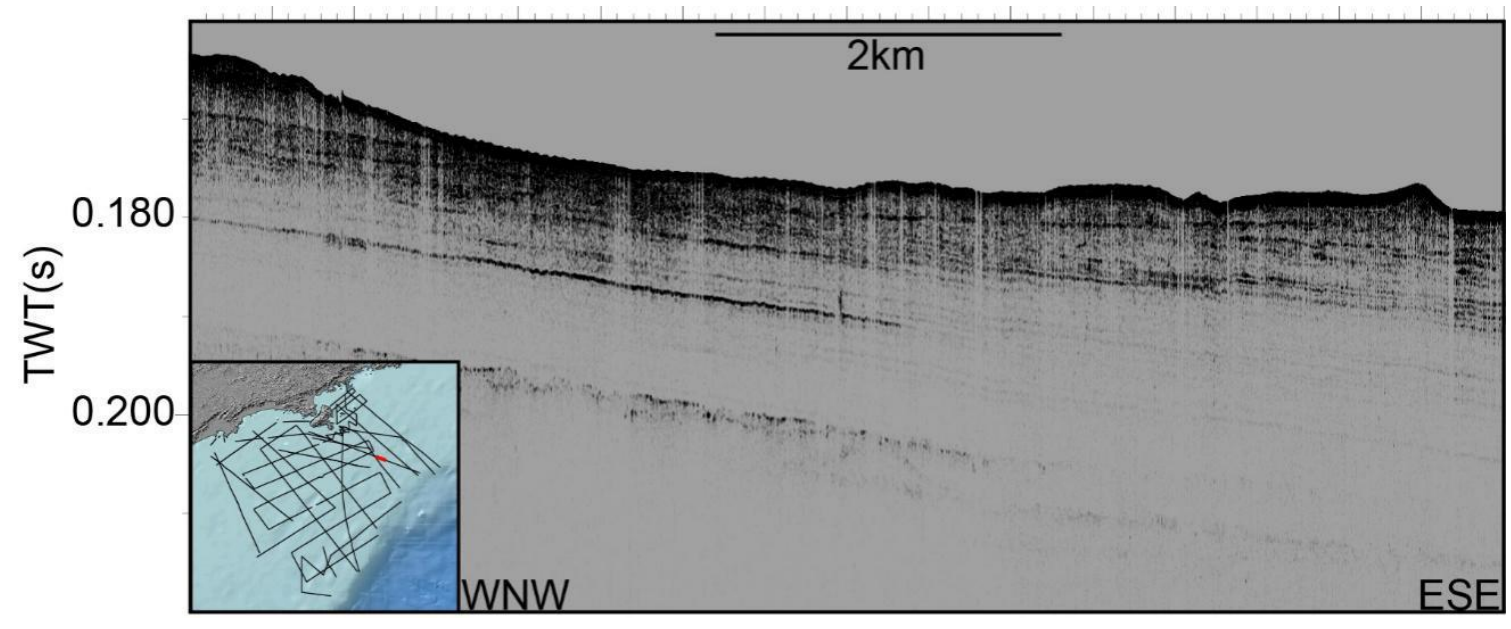

Figure 40. Echo type 3-2 on the outer shelf with parallel sub-bottom configuration

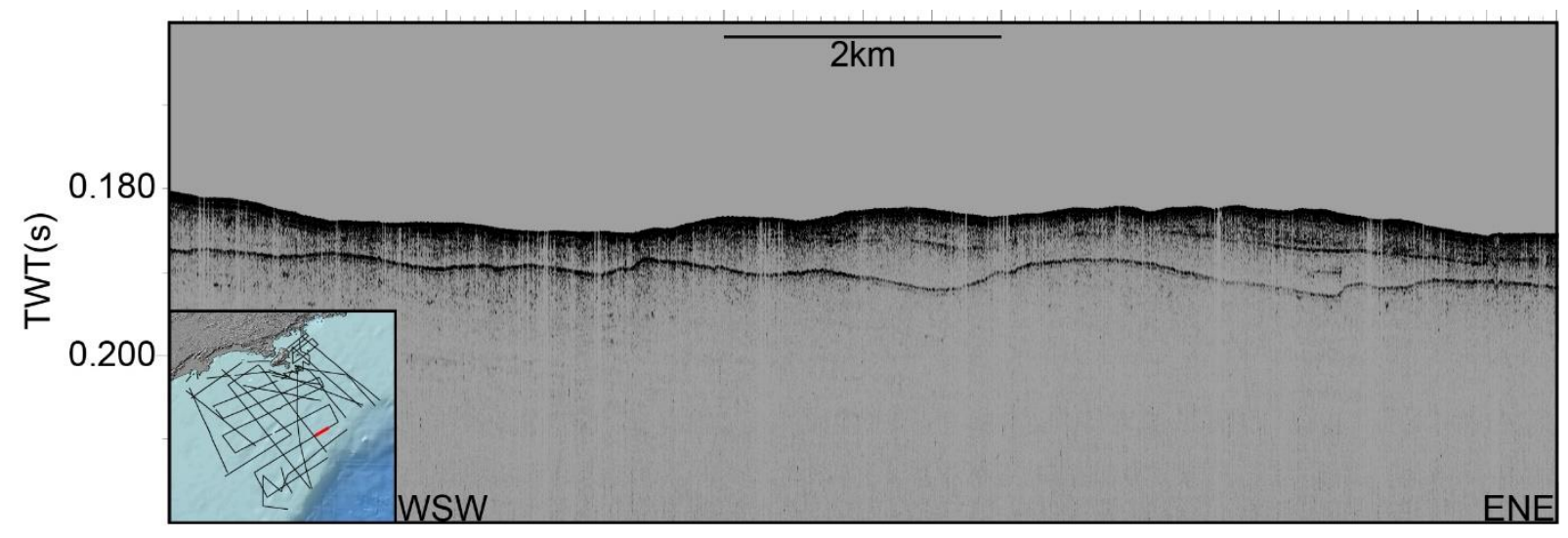

Figure 4I. Echo type 3-2 on the outer shelf with thickening and thinning of internal reflectors

\subsubsection{I2. Area 12 (echo type I-I)}

This area extends for approximately $800 \mathrm{~km}^{2}$ and it is located on the central outer shelf from 100 to 150 meters water depth. It is marked by the echo type I-I, i.e., a basically flat seafloor, despite the occurrence of isolated seafloor irregularities. This region exhibits high cabonatic (70-90\%) and low mud (less than $20 \%$ ) contents.

\subsubsection{Area I3 (echo type I-3)}

This area extends for approximately $100 \mathrm{~km}^{2}$ and it is located on the northeastern outer shelf from I00 to I30 meters water depth. It is covered by echo type I-3 that exhibits higher slopes than the surrounding areas, a surficial transparent echo up to 5 meters thick and 
penetration up to 18 meters. This region displays medium amounts of $\mathrm{CaCO}_{3}(40-60 \%)$ and mud $(20-40 \%)$ contents.

\subsubsection{I4. Area $I 4$ (echo types $I-I, I-4$ and $2-I$ )}

This area occupies approximately $1,600 \mathrm{~km}^{2}$ and it is located on the central middle shelf from I30 to 170 meters water depth at the shelf break. This area is characterized by echoes $\mathrm{I}-\mathrm{I}, \mathrm{I}-4$ and $2-\mathrm{I}$. Although only echo I-4 is described as undulated, 2-I echo 2-I also shows some undulations in this area. All the three echo types in this region display semi-prolonged bottom echos and little sub-bottom reflections. This area is marked by high cabonatic contents (more than 60\%) and low amounts of mud (less than 40\%). 


\section{Discussion}

The distribution patterns of echo characters is supposed to reflect the surficial sediment distribution for a specific area; consequently, a correlation is expected to be found between both parameters (Damuth, 1975; Damuth, 1980; Pratson and Laine 1989). Also, they are thought to provide clues about the dominant sedimentary processes, although the relationship is not exclusive (Damuth, 1980).

In general, in the study area echo types distribution patterns are arranged parallel to the coast; therefore, a bathymetric control can be assumed. In non-deltaic continental shelves, the distribution of surficial sediments also seems to be dictated to a large extent by the range of water depths. In this sense, sands tend to cover most of the nearshore. The inner and middle shelves tend to be covered by variable amounts of muds and sands, whereas the outer shelf is mainly composed of carbonatic sediments (Reddy and Rao, 1997). Therefore, it can be stated that in the study area the bathymetrical zonation of echo character is reflecting to a large extent a sedimentological zonation as well.

The spatial correlation between the echo character types and the studied sedimentological parameter can be used to refine the significance of echo character analysis as a sedimentological predictor (Figures 42 to 45 ). For example, echo type I-3 is the only type found in areas showing high mud contents, while echoes I-I, I-2, I-4, 2-I, 3-I and 3-2 are located in areas of low mud content. Concerning calcium carbonate content, echoes I-I, I-4, 2-I, 3-I and 3-2 are located in areas of high $\mathrm{CaCO}_{3}$ content, while echoes I-2 and I-3 appear more frequently in low $\mathrm{CaCO}_{3}$ content areas 


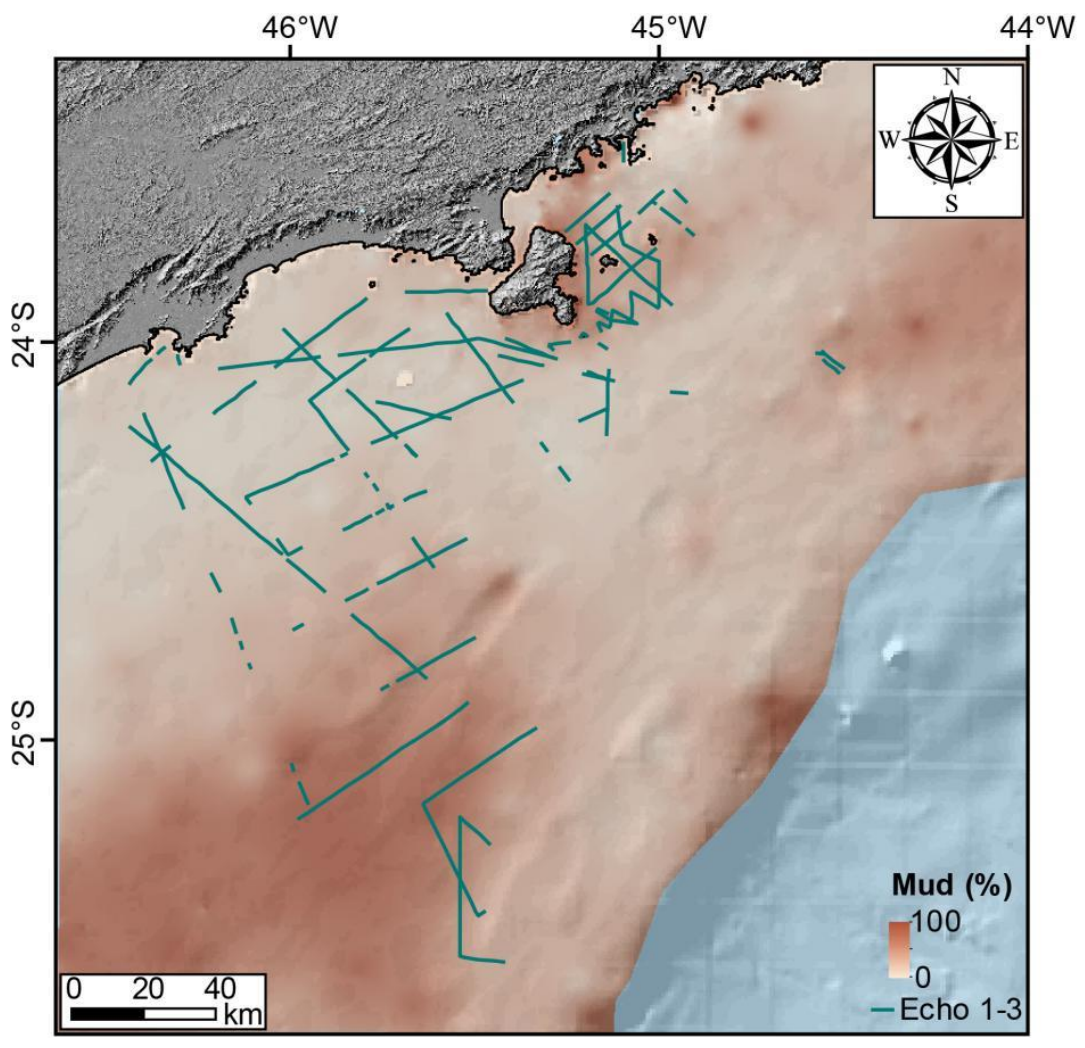

Figure 42. Echo $I-3$ is found in high mud content areas

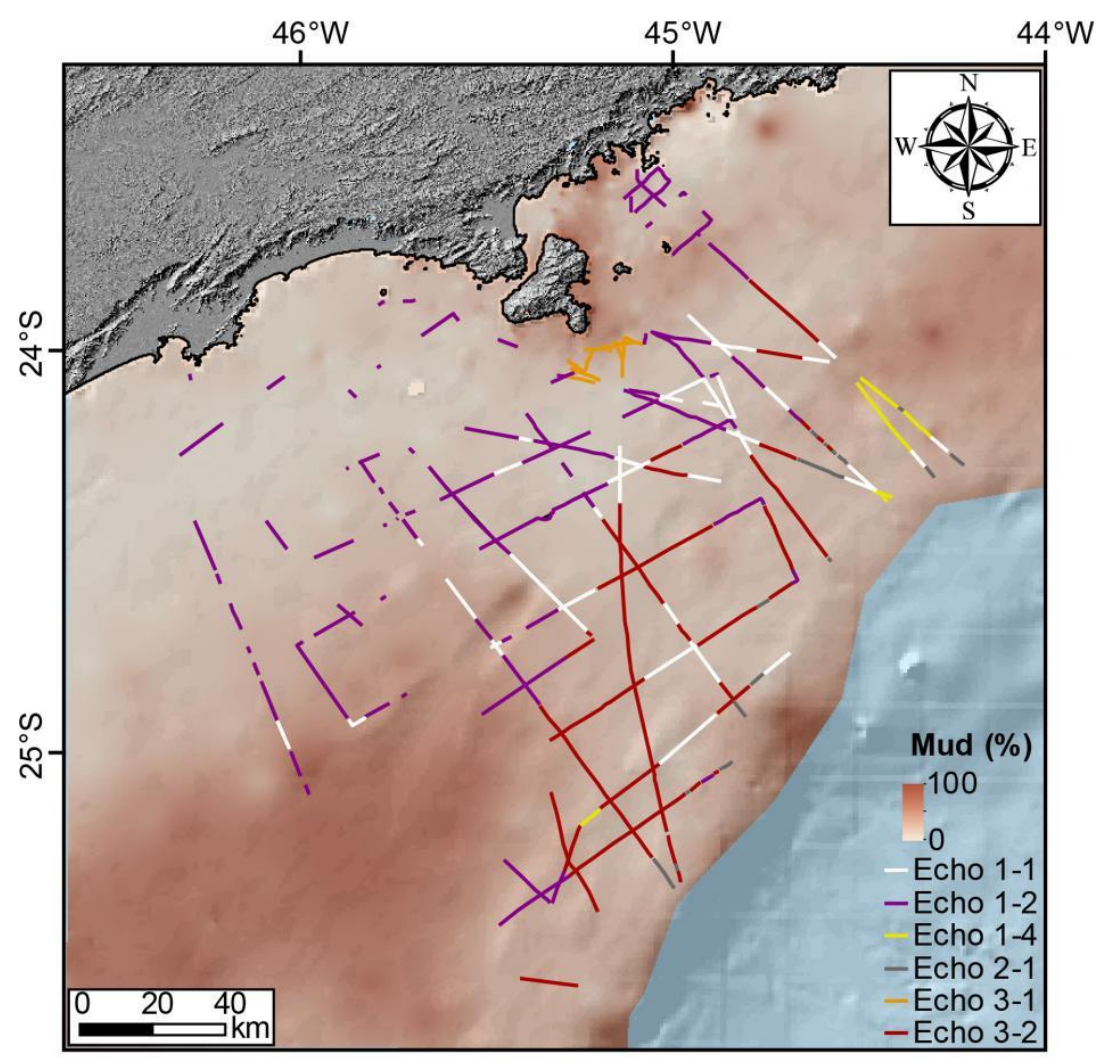

Figure 43. Echo types that correlate to low mud content 


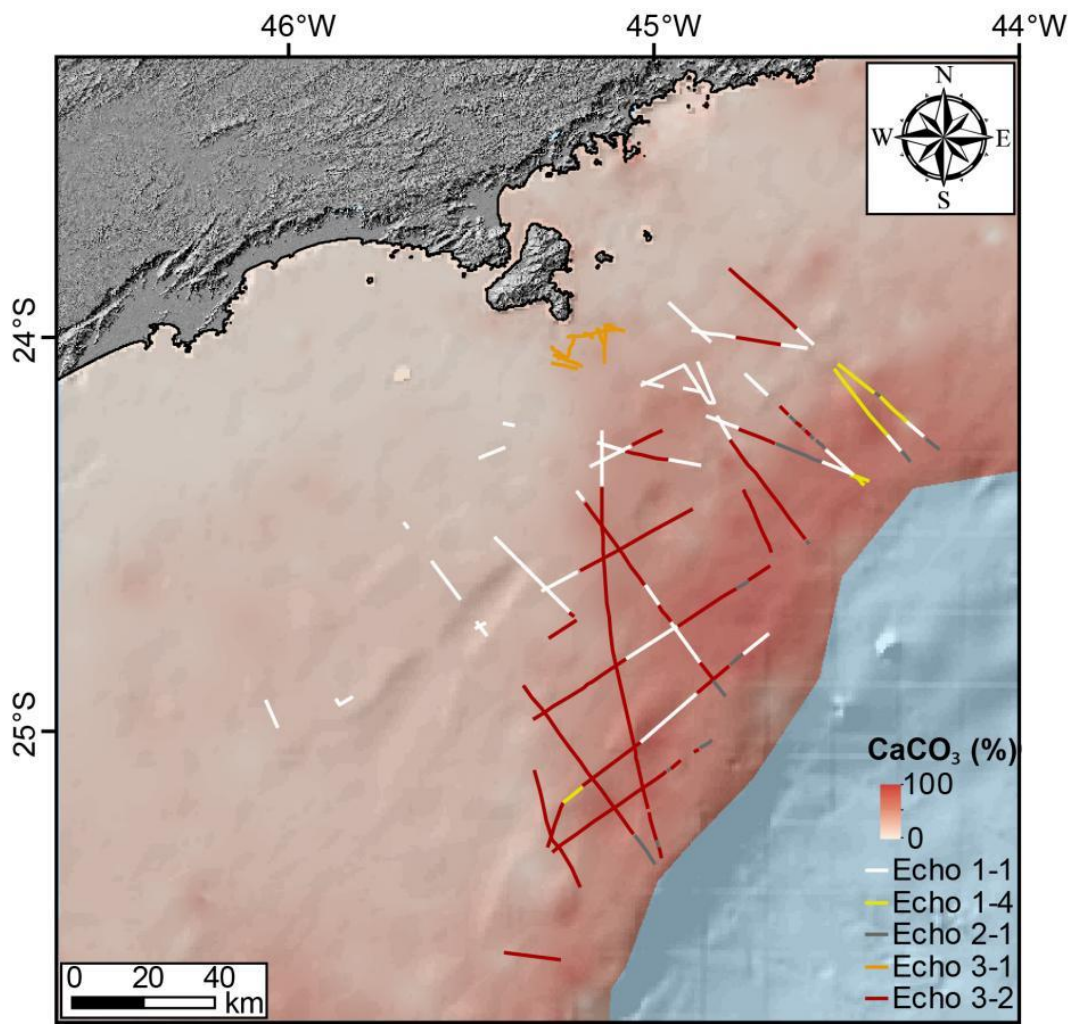

Figure 44. Echo types that correlate to high calcium carbonate content

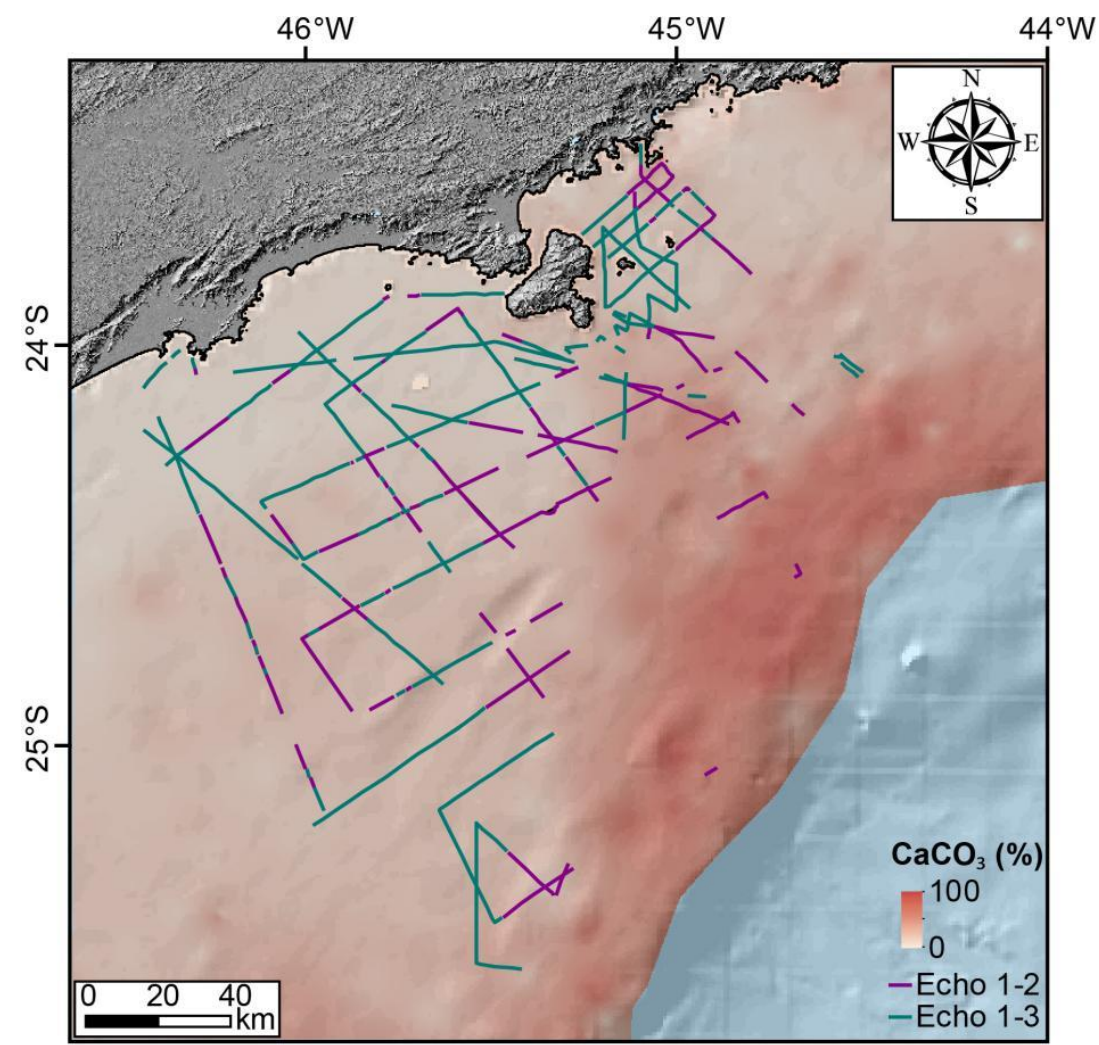

Figure 45. Echo types that correlate to low calcium carbonate content 
The heterogeneity of sedimentary environments is very evident, mainly in the northeastern sector, which demonstrates a great complexity regarding hydrodynamics and sedimentary processes on this shelf sector (Figure 46).

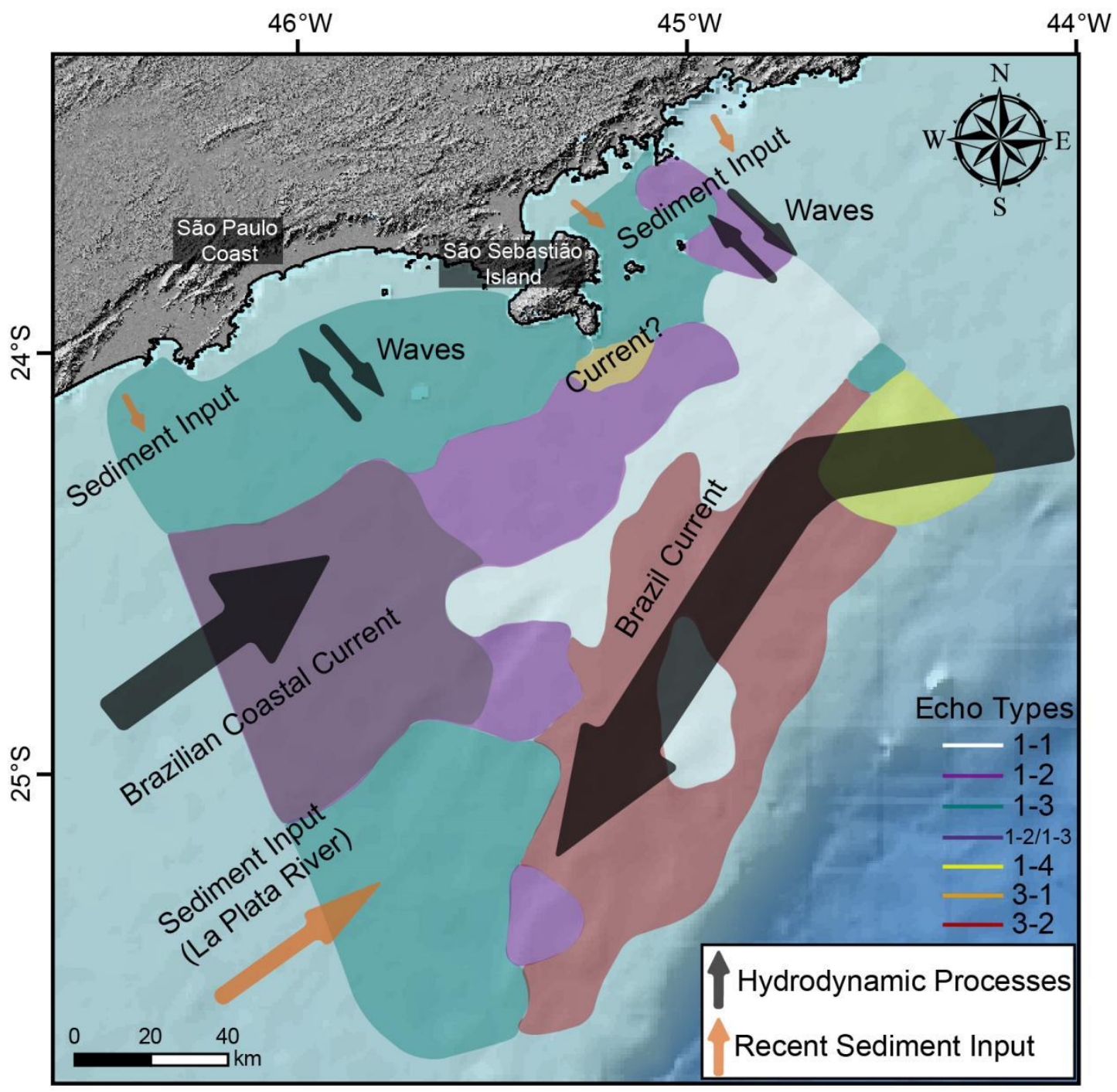

Figure 46. Summary of recent sedimentary processes and driving mechanisms interpreted in the study

The synthesis of the echo types, their mud and calcium carbonate contents, shelf distribution and the interpreted associated processes are shown in Table I. 
Table I. Description and interpretation of echo types

\begin{tabular}{|c|c|c|c|c|c|c|}
\hline $\begin{array}{l}\text { Echo } \\
\text { Type }\end{array}$ & $\begin{array}{l}\text { Seismic } \\
\text { Example }\end{array}$ & Description & $\begin{array}{c}\text { Mud } \\
\text { Content }\end{array}$ & $\begin{array}{c}\mathrm{CaCO}_{3} \\
\text { Content }\end{array}$ & Interpretation & $\begin{array}{c}\text { Shelf } \\
\text { distribution }\end{array}$ \\
\hline $1-1$ & 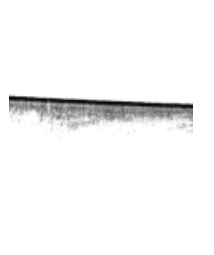 & $\begin{array}{l}\text { Flat sea floor } \\
\text { with either } \\
\text { no or low- } \\
\text { amplitude } \\
\text { sub-bottom } \\
\text { reflectors }\end{array}$ & $<40 \%$ & $20-100 \%$ & $\begin{array}{l}\text { Middle shelf } \\
\text { relict sands }\end{array}$ & $\begin{array}{c}\text { Middle/ } \\
\text { Outer Shelf }\end{array}$ \\
\hline $\mathrm{I}-2$ & PY & $\begin{array}{l}\text { Flat sea floor } \\
\text { with medium } \\
\text { to high- } \\
\text { amplitude } \\
\text { sub-bottom } \\
\text { reflectors }\end{array}$ & $<40 \%$ & $<40 \%$ & $\begin{array}{l}\text { Pre-Holocenic } \\
\text { deposit }\end{array}$ & Middle Shelf \\
\hline $1-3$ & $\overline{\text { mathenty }}$ & $\begin{array}{l}\text { Transparent } \\
\text { superficial } \\
\text { layer followed } \\
\text { by a high } \\
\text { reflective } \\
\text { reflectors } \\
\text { (echo I-2 ) }\end{array}$ & - & $<40 \%$ & $\begin{array}{l}\text { Wedges, mud } \\
\text { depocenters, } \\
\text { and nearshore } \\
\text { fine sands }\end{array}$ & $\begin{array}{c}\text { Inner Shelf/ } \\
\text { Southwest } \\
\text { outer shelf/ } \\
\text { Northeast } \\
\text { outer shelf }\end{array}$ \\
\hline $\mathrm{I}-4$ & & $\begin{array}{l}\text { Flat seafloor } \\
\text { covered by } \\
\text { regularly } \\
\text { spaced } \\
\text { seafloor } \\
\text { undulations }\end{array}$ & $<40 \%$ & $>60 \%$ & $\begin{array}{l}\text { Subaqueous } \\
\text { dune fields }\end{array}$ & Outer Shelf \\
\hline $2-1$ & & $\begin{array}{l}\text { Prolonged } \\
\text { mounded } \\
\text { echo with no } \\
\text { internal } \\
\text { reflectors }\end{array}$ & $<40 \%$ & $>60 \%$ & Sand ridges & Outer Shelf \\
\hline $3-1$ & & $\begin{array}{l}\text { Irregular echo } \\
\text { with } \\
\text { prolonged } \\
\text { internal } \\
\text { reflectors. } \\
\text { Surrounded } \\
\text { by flat echoes }\end{array}$ & $<20 \%$ & $20-40 \%$ & $\begin{array}{c}\text { Small-scale } \\
\text { shallow channels }\end{array}$ & $\begin{array}{l}\text { Inner Shelf } \\
\text { (São } \\
\text { Sebastião } \\
\text { Island) }\end{array}$ \\
\hline $3-2$ & & $\begin{array}{l}\text { Broad } \\
\text { irregular echo } \\
\text { with high } \\
\text { relief } \\
\text { variations }\end{array}$ & $<40 \%$ & $>40 \%$ & $\begin{array}{c}\text { Regressional or } \\
\text { transgressional } \\
\text { features } \\
\text { influenced by the } \\
\text { Brazil Current }\end{array}$ & Outer Shelf \\
\hline
\end{tabular}




\section{I. Sedimentological implications and sedimentary processes}

\section{I.I. Inner Shelf (Areas I,2,3 and 4)}

Echo types with high signal penetration are associated to muddy sediments (Damuth, 1980). The southwestern inner shelf is covered by fine to very fine sands up to 50-meter depth (Conti and Furtado, 2016). As Area I is mainly covered by echo type I-3, it can be inferred that fine sands on the inner shelf can permit acoustic signal penetration in the study area. Another factor that allows acoustic signal penetration is the small thickness of this fine sand layer, which is up to 5 meters thick. The occurrence of some low amplitude sub-surface layers in I-3 echo type is possibly due to the intercalation of mud and fine sands.

In Area I, the inner shelf is mainly covered by relict sands (Mahiques, 2004) with low sedimentation rates (up to $70 \mathrm{~cm} \mathrm{kyr}^{-1}$ ). Moreover, Mahiques (20II) has described samples in this area that presented age inversions. These facts are indicative of the dominance of sediment reworking processes. The combined influence of wind-driven waves and the Brazilian Coastal Current (Castro and Miranda, 1998) that is associated with the passage of cold fronts in the austral winter could explain the dominance of reworking processes in this inner area. Therefore, echo type I-3 in Area I is interpreted as a surficial relict fine sand sheet, which has been reworked above older Pleistocene deposits.

Echo type $\mathrm{I}-3$ is also found on the northeast inner shelf off SSI, where it is characterizing a thick (average thickness of $24 \mathrm{~m}$ ) and laterally extensive (several tens of $\mathrm{km}$ ) nearshore wedge. In this area (Area 2) the mud contents are higher than in the southwestern inner shelf, as the wedge is mainly composed of medium-to-coarse silts. Such deposit was interpreted as a non-deltaic clinoform wedge, partially fed from the combined input of several small rivers (Vieira et al., 2018).

Acoustic facies lacking penetration were detected in a restricted area within the São Sebastião Wedge. These facies are regarded as acoustic blanking since they show a high reflective internal reflector on the top (Baltzer et al., 2005). This type of acoustic facies is related to the presence of shallow gas (Catanzaro et al., 2004; Garcia-Garcia et al., 2004). There are two possible origins of gas in flat areas: thermogenic, which requires gradients of temperature and pressure; and biogenic gas, by the reduction of organic matter by bacterial 
activity (Floodgate and Judd, 1992). Values of total organic carbon up to $1.6 \%$ were found on the São Sebastião Wedge (Spera, 2016), which are the highest values on the inner shelf in the study area (Mahiques, 2004). Therefore, a biogenic origin is attributed to the acoustic anomalies found in the wedge.

The echo type I-2 found at the lateral end of the wedge (Area 3) is interpreted as relict terrigenous sands reworked by wind-driven waves.

The presence of 3-I echo type marks Area 4. Acoustic echoes similar to echo 3-I have been interpreted as the result of highly energetic processes, such as locally focused currents (Chough et al., 2002). The occurrence of reflection truncations could be indicative of erosional processes, such as reworking of relict materials. Additionally, the occurrence of acoustic echo 3-I off a pronounced seafloor slope can provide additional genetic clues. A strong, seasonally variable wind-driven current near SSI has been reported by a mathematical model output. This current flows preferentially to the west with surface velocities up to $3 \mathrm{~m} / \mathrm{s}$ and depth-averaged velocity of $0.63 \mathrm{~m} / \mathrm{s}$ (Fortes, 20l8) (Figure 47). The occurrence of acoustic echo $3-\mathrm{I}$ is possibly related to seafloor erosion by the wind-driven current, that would also prevent recent deposition. Since similar acoustic echoes are observed at depths in nearby areas, the current activity seems to have persisted during the recent geological past. 


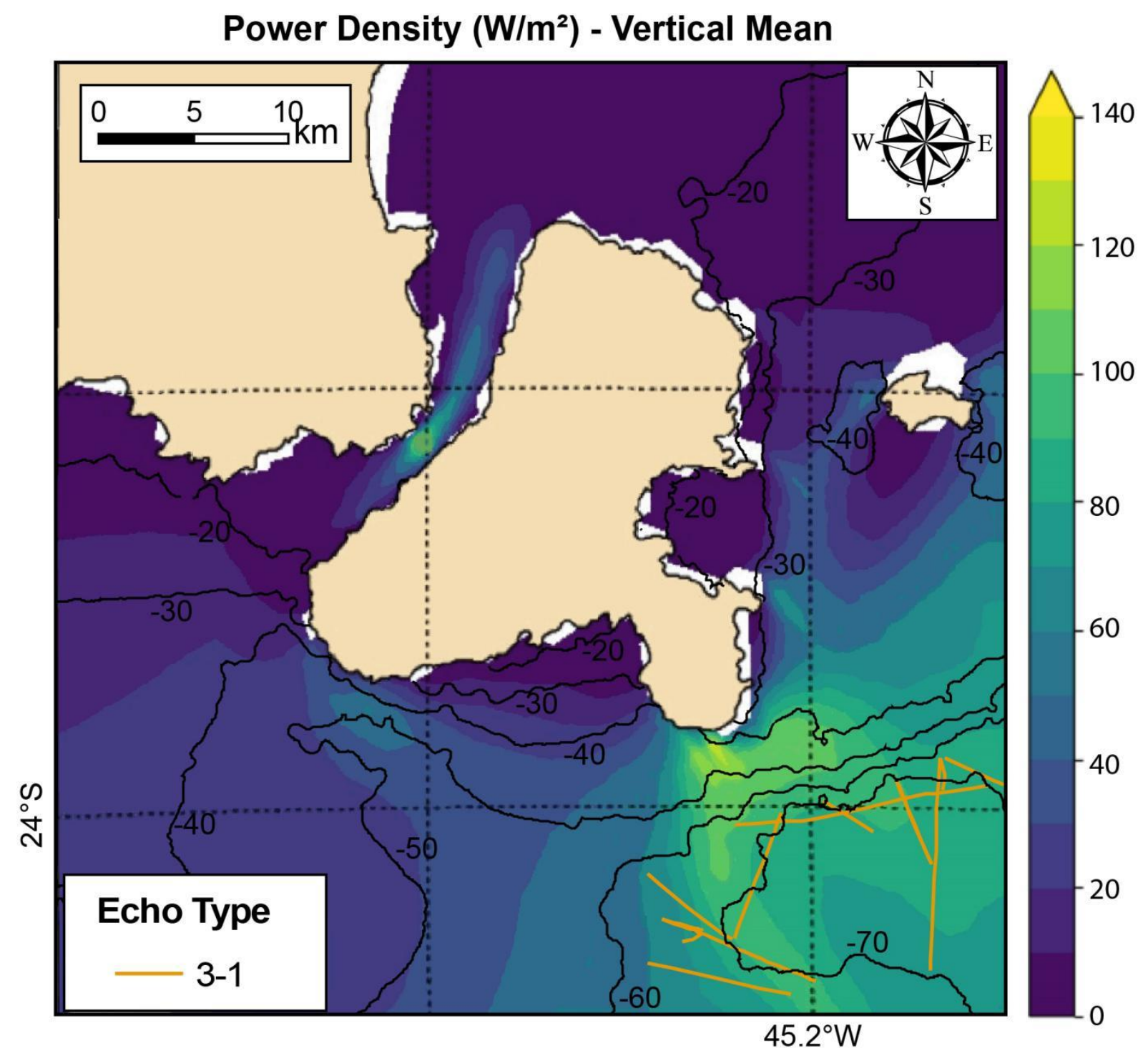

Figure 47. Vertical mean of power density measures with echo type 3-2 lines (Adapted from Fortes, 2018)

\section{I.2. Middle Shelf (Areas 5,6 and 7)}

Area 5, that exhibits both echo types I-2 and I-3, is located at the transition between two different regions with distinct sedimentary processes and hydrodynamic patterns. Recent deposition is possibly occurring in Area 5, since mud contents increase towards the outer shelf. It is proposed that the prevalence of mud contents could probably reflect the penetration of the La Plata river plume along the southwestern shelf of the São Paulo Bight that carries modern sediments from La Plata estuary up to $24^{\circ} \mathrm{S}$ (Piola et al., 2000). Therefore, this area is influenced by two different currents with opposite directions, such as BCC and BC, which might favor sediment deposition (represented by echo I-3). 
Echo type I-2 (Area 6) shows deeper acoustic penetration compared to echo I-I (Area $7)$, which suggests that surface sediments are relatively finer. Mud content in this area is low, but fine to very fine sands and the low $\mathrm{CaCO}_{3}$ content are both factors that enable signal penetration. The various reflection geometry in the subsurface reflects pre-Holocene deposits of river environments (Chough et al., 2002). These deposits are interpreted as buried fluvial channels (Pratson and Laine, 1989) filled with alternated layers of mud and sand.

Very strong and sharp bottom echoes with poor sound penetration similar to echo I-I reflect a seafloor covered with coarse-grained sediments (Damuth and Hayes, 1977; Damuth, 1980). This echo is mostly sharp, but the local occurrence of dissipated bottom echo may indicate irregularities of the seafloor.

Middle shelf sediments have been interpreted either as lagoonal or beach relict sediments (Mahiques et al., 2004). According to the present analysis, Area 7 represented by echo type $\mathrm{I}-\mathrm{I}$ is interpreted as relict coarse sediments resulting from very energetic processes, which cause erosion or non-deposition.

The echo type I-2 in Area 8 is similar to echo I-I in Area 7, but some internal reflectors are visible probably due to the relatively increase in mud content which favor acoustic signal penetration. Thus, area 8 is interpreted as a transitional muddy sand area between Areas 7 (sandy) and 9 (muddy).

\section{I.3. Outer Shelf}

The occurrence of echo type I-3 in the southwestern part of the outer shelf (Area 9) and the spatial correlation with the highest mud contents could be related to a mud depocenter which has been described in previous studies (Mahiques et al., 2004; Mahiques et al., 2008; Gyllencreutz et al., 20I0; Nagai et al., 2014) and which is composed by recent sediment from the La Plata river (Mahiques et al., 2008).

Similarly to Area 8, Area 10 has been interpreted as a transitional region between muddy terrigenous sediment from the depocenter in Area 9 and carbonatic sands in Area II due to the decreasing signal penetration to the northeast. In fact, this trend of decreasing signal penetration as a response of a change of sediment patterns is also observed in all contact between echoes I-3 and 3-2 in the Areas 9 and II, respectively (Figure 48). 


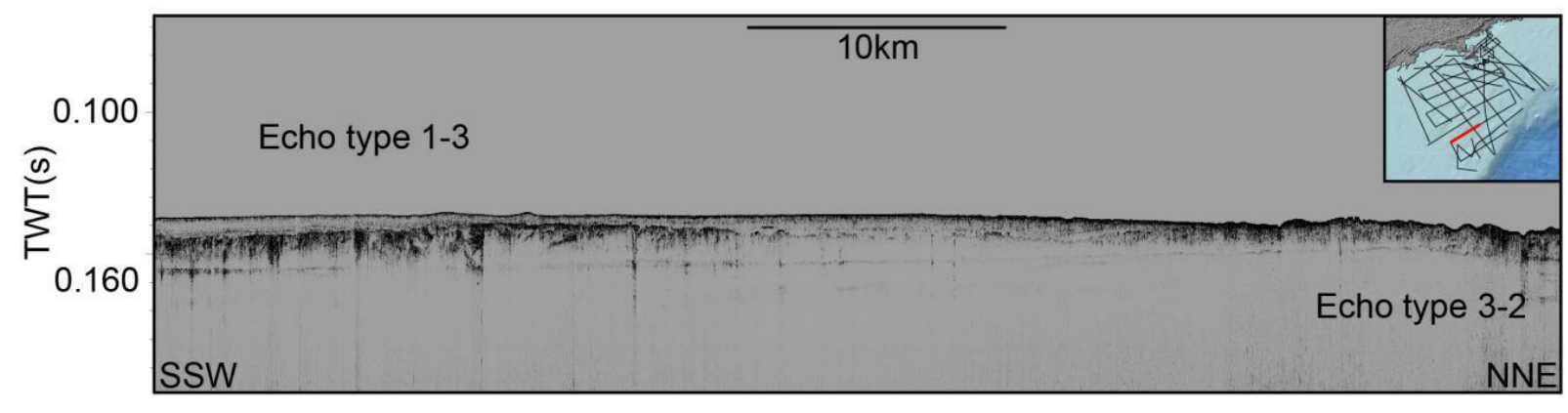

Figure 48. Transition area between echoes I-3 and 3-2

The morphological complexity observed in Area II (3-2 echo type) is reflecting a multiplicity of sedimentary processes, possibly also guided by transient sea levels over most of the outer shelf.

The dipping reflectors found in some seismic lines of 3-2 echo type may be linked to autocyclic sedimentary processes (Garcia-Garcia et al., 2004) such as seaward progradation of regressive prodelta muds (Rad and Tahir, 1997), or be the product of mound-shaped bedform migration. Indeed, the thickening, thinning or truncation of internal reflectors across the sea bottom observed in this area, seems to be compatible with the activity of migrating sediment waves formed by currents (Damuth, 1980).

In Area I I, a relatively flat, gently inclined surface with several hundred meters in length and a visible scarp morphology (Figure 39) is interpreted as a terrace, located at 120 meters water depth, which is the depth that marks the maximum regression in the São Paulo Bight (Conti and Furtado, 2016). Similar features are commonly found in the middle and outer shelf (Wagle et al., 1994), usually as the product of wave-ravinement during the Holocene transgression (Chough et al., 2002).

Previous studies report a negligible sedimentation rate on the outer shelf (Mahiques et al., 20II) associated with the main flux of the Brazil Current on the northern sector of the study area, which acts as a "floor-polisher" on the sea bottom (Mahiques et al., 2002; Mahiques et al., 2004). Also, some carbonate patches and bioclastic belts have been reported between 100 and 200 meters depth (Mahiques et al., 2004). These characteristics could explain the general pattern of carbonatic sands in Area II. 
On the northeastern outer shelf, Area 13 is located in a region with a clear trend of increasing mud content that could reflect quieter environmental conditions, since the $B C$ is deflected to south-southwestern in this region (Calado et al., 2008).

The seismic profiles located next to Area 13 present an irregular seafloor, but with parallel sub-bottom reflectors (Figure 40), which might be related to pelagic sedimentation processes and high carbonate content (Pratson and Laine., 1989). The erosional surface is possibly a result of the Brazil Current flux.

The northeastern outer shelf (Area 14) is mainly covered by echoes exhibiting wavy features, which are pervasive in echo I-4 and also found in surrounding echoes $2-\mathrm{I}$ and 3-2, although less frequent and with lower sizes. Regular wavy echoes representing sediment waves can be produced by the action of geostrophic bottom currents impinging on the seafloor (Heezen et al., 1966; Hollister and Heezen, 1972; Schneider et al., 1967). Therefore, these outer shelf echoes are interpreted as dune fields created by the meandering BC.

Prolonged echoes similar to echo 2-I are the result of the scattered acoustic signal from the sea-bottom and are linked with small irregularities on the microtopography (Damuth, 1975). Chough et al. (2002) interpreted this echo type as formed by tidal waves. However, the study area is a microtidal environment, which turns refutable the hypothesis of an expressive influence of tidal waves on the construction of echo type 2-I.

Sand Ridges are large bedforms (I to $4 \mathrm{~km}$ wide; 2 to $10 \mathrm{~km}$ long; 2 to $6 \mathrm{~m}$ high) oriented accordingly to regional contours and usually formed in a near shore environment (e.g., Swift and Field, 198I). Since echo type 2-I is located in the outer shelf of the study area, it is considered that they could represent sand ridges formed at the beginning of the postglacial transgression by the influence of the BC. 


\section{Conclusion}

The analysis of the seismic survey also allowed to recognize that the distribution of the echoes reflects not only the composition of the seabed but also the sedimentary processes that acted during the deposition of the material. The echo characters identified in the study area evidenced the occurrence of distinct sedimentation patterns on the inner, middle and outer shelf. In addition, the SSI also marks a distinct boundary that determines the spatial variability of sedimentary processes in short distances:

- The inner shelf is mainly a flat featureless area covered by relict fine sands controlled by the interaction of wind-driven waves and the Brazilian Coastal Current. Within the inner shelf, the SSI constitutes a morphological barrier that causes significant modification of sedimentary processes. By one hand, it enables the deposition of a kilometric-scale sediment wedge on one side of the wedge, where acoustic anomalies indicate the formation of gas. By the other hand, its southernmost tip is possibly focusing current activity that formed an erosional area.

- Middle shelf presents different sedimentation patterns in the southwest and the northeast. In the southwest, the interaction between the BCC and the BC favors deposition, which results in recent deposits of mud from the La Plata River. Towards northeast, there is a trend of increasing grain size, which gradually inhibits the acoustic signal penetration. This northeastern deposit is possibly relict coarse sediments resulting from very energetic processes, which cause erosion or non-deposition.

- Most of the sedimentation patterns on the outer shelf seem to be controlled by the flux of the BC; particularly, the widespread occurrence of seafloor undulations constitutes the most pervasive imprint of the current, and would indicate bedform development in the outer shelf. However, the high mud contents observed in the southwestern outer shelf signal to the northernmost influence of the huge La Plata River sediment input. 


\section{Final Remarks}

A single echo character study had been conducted on the São Paulo shelf until the present work. That study, made by Damuth (1975), found only one echo type on the shelf. Now, the recognition of seven echo types in the study area has proved that the morphology and the sedimentary processes on São Paulo Continental Shelf are more complex than previously assumed, especially on the outer shelf. Futures studies in this region should take the above information into account for the scaling of the seismic and sedimentary surveys. 


\section{References}

ALMEIDA, F.F.M.; CARNEIRO, C.D.R.; MIZUSAKI, A.M.P. Correlação do magmatismo das bacias da margem continental brasileira com $\circ$ das áreas emersas adjacentes. Revista Brasileira de Geociências, v. 26, n. 3, p. 125-138, 1996.

ALVES, J.H.M. et al. Reconstituição do clima de ondas no Sul e Sudeste brasileiro entre 1997 e 2005. Revista Brasileira de Geofísica, v. 27, p, 427-445, 2009.

ArcGIS ESRI, 2016. How IDW Works. 2016. Available at: <http://desktop.arcgis.com/en/arcmap// 0.3/tools/3d-analyst-toolbox/how-idw-works.htm>. Acessed March 2018.

AYRES NETO, A. Uso da sísmica de reflexão de alta resolução e da sonografia na exploração mineral submarina. Brazilian Journal of Geophysics, v. I8, n. 3, p. 24I-256, 2000.

AYRES NETO, A.; FALCAO, L.C.; AMARAL, P.J.T. Caracterização de ecofácies na margem continental norte Brasileira: estado do conhecimento. Revista Brasileira de Geofísica, São Paulo, v. 27, supl. I, p. 097-I06, 2009.

BALTZER, A. et al. Seistec seismic profiles: a tool to differentiate gas signatures. Marine Geophysical Researches, v. 26, n. 2-4, p. 235-245, 2005.

BELO, W.C.; DIAS, G.; DIAS, M.S. O fundo marinho da baía da llha Grande, RJ: o relevo submarino e a sedimentação no canal central. Revista Brasileira de Geofísica, v. 20, n. I, p. 5-15, 2002.

BEXIGA, G.M.S. Estudo geoacústico para mapeamento de eco-caráter em registros sísmicos de alta resolução do interior da Lagoa Dos Patos, RS, Brasil. 2016.

BONI, G.C. Ecocaráteres e processos sedimentares na plataforma continental adjacente à desembocadura do Rio Doce (ES). Dissertação de Mestrado - Universidade Federal do Espírito Santo, Espírito Santo, 2016.

BRANDINI, F.P. et al. Deep chlorophyll maximum and plankton community response to oceanic bottom intrusions on the continental shelf in the South Brazilian Bight. Continental Shelf Research, v. 89, p. 61-75, 2014

BRIGGS, K.B. et al. Fine-scale sedimentary structure: implications for acoustic remote sensing. Marine Geology, v. 182, n. I, p. I4I-159, 2002. 
CALADO, L.; GANGOPADHYAY, A.; DA SILVEIRA, I. C. A. Feature-oriented regional modeling and simulations (FORMS) for the western South Atlantic: Southeastern Brazil region. Ocean Modelling, v. 25, n. I-2, p. 48-64, 2008.

CAMPOS, E.J.; PIOLA, A.R.; MILLER, J.L. Water mass distribution on the shelf and shelf-break upwelling in the Southeast Brazil Bight. Naval research lab stennis space center ms mesoand finescale ocean physics section, 1999.

CASTRO, B.M.; MIRANDA, L.B. Physical oceanography of the western Atlantic continental shelf located between $4 \mathrm{~N}$ and 34 S. The sea, v. II, n. I, p. 209-25I, 1998.

CASTRO, B.M. Summer/winter stratification variability in the central part of the South Brazil Bight. Continental Shelf Research, v. 89, p. 15-23, 2014.

CATANZARO, L.F. et al. Distinctive sedimentary processes in Guanabara Bay-SE/Brazil, based on the analysis of echo-character $(7.0 \mathrm{kHz})$. Revista Brasileira de Geofísica, v. 22, n. I, p. 69-83, 2004.

CHOUGH, S.K. et al. High-resolution acoustic characteristics of epicontinental sea deposits, central-eastern Yellow Sea. Marine Geology, v. I88, n. 3, p. 317-33I, 2002.

CONTI, L.A.; FURTADO, V.V. Geomorfologia da plataforma continental do Estado de São Paulo. Revista Brasileira de Geociências, v. 36, n. 2, p. 305-3I2, 2016.

COOKE, C.V. et al. Análise de dados de ecossondagem de fundo oriundos de cruzeiros realizados entre Fortaleza (CE) e Chuí (RS) com enfoque na morfologia e tipos de fundo. Revista Brasileira de Geofísica, v. 25, n. 4, p. 443-457, 2007.

DAMUTH, J.E. Echo character of the western equatorial Atlantic floor and its relationship to the dispersal and distribution of terrigenous sediments. Marine Geology, v. I8, n. 2, p. I745, 1975.

DAMUTH, J.E.; HAYES, D.E. Echo character of the east Brazilian continental margin and its relationship to sedimentary processes. Marine Geology, v. 24, n. 2, p. 73-95, 1977.

DAMUTH, J.E. Echo character of the Norwegian-Greenland Sea: relationship to Quaternary sedimentation. Marine Geology, v. 28, n. I-2, p. I-36, 1978. 
DAMUTH, J.E. Use of high-frequency $(3.5-12 \mathrm{kHz})$ echograms in the study of near-bottom sedimentation processes in the deep-sea: a review. Marine Geology, v. 38, n. I, p. 5 I-75, 1980.

DAMUTH, J.E.; OLSON, H.C. Latest Quaternary sedimentation in the northern Gulf of Mexico Intraslope Basin Province: I. Sediment facies and depositional processes. Geosphere, v. II, n. 6, p. 1689-1718, 2015.

DECO Geophysical Software Company. RadExPro Plus v. 2014.3 User Manual. Moscow. 2014 DOTTORI, M.; CASTRO, B.Ms. The response of the Sao Paulo Continental Shelf, Brazil, to synoptic winds. Ocean dynamics, v. 59, n. 4, p. 603-6I4, 2009.

ELLIOTT, T. Chapter 6. Deltas. Sedimentary Environments and Facies, 2nd Edition: Oxford, UK, Blackwell, p. 155-188, 1986.

FELIX, C. A. Evolução quaternária superior e formação de gás raso em ambiente estuarino tropical: o caso do Canal de Bertioga, São Paulo. 20I2. Tese de Doutorado. Universidade de São Paulo.

FIGUEIREDO JR, A.G.; NITTROUER, C. A. New insights to high-resolution stratigraphy on the Amazon continental shelf. Marine Geology, v. I25, n. 3-4, p. 393-399, 1995.

FIGUEIREDO, A.G.; TESSLER; M.G. Topografia e composição do substrato marinho da região Sudeste-Sul do Brasil. 2004.

FLOODGATE, G.D.; JUDD, A.G. The origins of shallow gas. Continental Shelf Research, v. I2, n. I0, p. II45-II56, 1992.

FORTES, J.F. Avaliação do potencial de energias marinhas na região de São Sebastião. Dissertação de Mestrado, Universidade de são Paulo, São Paulo, 2018

FRAPPA, M.; PUJOS, M.. Late Quaternary evolution of the French Guiana continental shelf: evidence from 3.5 kHz data. Marine Geology, v. I2I, n. 3-4, p. 23 I-245, 1994.

GAO, S.; COLLINS, M. B. Holocene sedimentary systems on continental shelves. Marine Geology, v. 352, p. 268-294, 2014.

GARCÍA-GARCÍA, A.; GARCÍA-GIL, S.; VILAS, F. Echo characters and recent sedimentary processes as indicated by high-resolution sub-bottom profiling in Ría de Vigo (NW Spain). Geo-Marine Letters, v. 24, n. I, p. 32-45, 2004. 
GYLLENCREUTZ, R. et al. Mid-to late-Holocene paleoceanographic changes on the southeastern Brazilian shelf based on grain size records. The Holocene, v. 20, n. 6, p. 863875, 2010.

HARRIS, P.T. et al. Geomorphology of the oceans. Marine Geology, v. 352, p. 4-24, 2014.

HEEZEN, B.C.; HOLLISTER, C.D.; RUDDIMAN, W.F. Shaping of the continental rise by deep geostrophic contour currents. Science, v. 152, n. 3721, p. 502-508, 1966.

HOLLISTER, C.D.; HEEZEN, B.C. Geologic effects of ocean bottom currents: Western North Atlantic. In: A.L. Gordon (Editor), Studies in Physical Oceanography Gordon and Breach, New York, v. 2, p.37-66, 1972.

HONG, E.; CHEN, I. S. Echo characters and sedimentary processes along a rifting continental margin, northeast of Taiwan. Continental Shelf Research, v. 20, n. 4, p. 599-617, 2000.

JONES, E.J. W. Marine Geophysics. UK, 1999.

KEAREY, P.; BROOKS, M.; HILL, I. Geofísica de exploração. Oficina de Textos, 2009.

KENNETT, J.P. Marine Geology. Prentice-Hall, Englewood Cliffs, N. J, 1982.

LEE, S.H. et al. Chirp (2-7-kHz) echo characters of the South Korea Plateau, East Sea: styles of mass movement and sediment gravity flow. Marine Geology, v. 184, n. 3-4, p. 227-247, 2002.

LEE, G.S. et al. Sedimentary environment and sequence stratigraphy of Late Quaternary deposits in the East China Sea. Marine Georesources \& Geotechnology, v. 3 I, n. I, p. I7$39,2013$.

LOURENÇO, T.S. Variabilidade interanual do clima de ondas e sua influência no litoral Sudeste e Sul do Brasil. Dissertação de Mestrado, Universidade de São Paulo, São Paulo, 2012.

MAGRANI, F. J.; AYRES NETO, A. Seismic characteristics and sedimentary distribution on the South Shetland Islands Continental Margin, Antarctica. Revista Brasileira de Geofísica, v. 32, n. 3, p. 549-560, 2014.

MAHIQUES, M.M.; SOUZA, L.A.P. Shallow seismic reflectors and upper Quaternary sea level changes in the Ubatuba region, São Paulo State, Southeastern Brazil. Revista Brasileira de Oceanografia, v. 47, n. I, p. 01-10, 1999. 
MAHIQUES, M.M.; MISHIMA, Y.; RODRIGUES, M. Characteristics of the sedimentary organic matter on the inner and middle continental shelf between Guanabara Bay and São Francisco do Sul, southeastern Brazilian margin. Continental Shelf Research, v. 19, n. 6, p. 775-798, 1999.

MAHIQUES, M.M. et al. Post-LGM sedimentation on the outer shelf-upper slope of the northernmost part of the São Paulo Bight, southeastern Brazil. Marine Geology, v. I8I, n. 4, p. 387-400, 2002.

MAHIQUES, M.M. et al. Hydrodynamically driven patterns of recent sedimentation in the shelf and upper slope off Southeast Brazil. Continental Shelf Research, v. 24, n. 15, p. 16851697, 2004.

MAHIQUES, M.M. et al. Sedimentary changes on the Southeastern Brazilian upper slope during the last 35,000 years. Anais da Academia Brasileira de Ciências, v. 79, n. I, p. I7I-I8I, 2007.

MAHIQUES, M.M. et al. Nd and $\mathrm{Pb}$ isotope signatures on the Southeastern South American upper margin: Implications for sediment transport and source rocks. Marine Geology, v. 250, n. I, p. 5I-63, 2008.

MAHIQUES, M.M. et al. The Southern Brazilian shelf: general characteristics, quaternary evolution and sediment distribution. Brazilian Journal of Oceanography, v. 58, n. SPE2, p. 25-34, 2010.

MAHIQUES, M.M. et al. Radiocarbon geochronology of the sediments of the São Paulo Bight (southern Brazilian upper margin). Anais da Academia Brasileira de Ciências, v. 83, n. 3, p. $817-834,20 I I$.

MAYER, L.A. Deep-sea carbonates: physical property relationships and the origin of highfrequency acoustic reflectors. Marine Geology, v. 38, n. I-3, p. I65-183, 1980.

MEISLING, K.E.; COBBOLD, P.R.; MOUNT, V.S. Segmentation of an obliquely rifted margin, Campos and Santos basins, southeastern Brazil. AAPG Bulletin, v. 85, n. II, p. 1903-1924, 2001 .

MENDOZA, U. et al. Geoacoustic character, sedimentology and chronology of a cross-shelf Holocene sediment deposit off Cabo Frio, Brazil (southwest Atlantic Ocean). Geo-Marine Letters, v. 34, n. 4, p. 297-3I4, 2014. 
MILLIMAN, J. D.; MEADE, R. H. World-wide delivery of river sediment to the oceans. The Journal of Geology, v. 9I, n. I, p. I-2I, 1983.

MOSHER, D.C.; SIMPKIN, P.G. Environmental marine Geoscience I. Status and trends of marine high-resolution seismic reflection profiling: Data acquistion. Geoscience Canada, v. 26, n. $4,1999$.

MULLINS, H.T.; BOARDMAN, M.R.; NEUMANN, A. Conrad. Echo character of off-platform carbonates. Marine Geology, v. 32, n. 3-4, p. 25I-268, 1979.

NAGAI, R.H. et al. Hydrodynamic controls on the distribution of surface sediments from the southeast South American continental shelf between $23 \mathrm{~S}$ and $38 \mathrm{~S}$. Continental shelf research, v. 89, p. 5I-60, 2014.

PALOMINO, D. et al. Estudio de los procesos sedimentarios recientes de la Bahía de la Palma a partir del análisis de la morfología y la respuesta acústica (Islas Baleares, Mediterráneo occidental). Revista de la Sociedad Geológica de España, v. 22, n. I-2, p. 79-93, 2009.

PARIS, P.J.; WALSH, J.P.; CORBETT, D.R. Where the continent ends. Geophysical Research Letters, v. 43, n. 23, 2016.

PIOLA, A.R. et al. Subtropical shelf front off eastern South America. Journal of Geophysical Research: Oceans, v. 105, n. C3, p. 6565-6578, 2000.

PRATSON, L.F.; LAINE, E.P. The relative importance of gravity-induced versus currentcontrolled sedimentation during the Quaternary along the mideast US outer continental margin revealed by $3.5 \mathrm{kHz}$ echo character. Marine Geology, v. 89, n. I, p. 87-I26, 1989.

PRATSON, L.F. et al. Seascape evolution on clastic continental shelves and slopes. Continental Margin Sedimentation: from sediment transport to sequence stratigraphy, p. 339-380, 2007.

POAG, C. W.; MOUNTAIN, G. S. Late Cretaceous and Cenozoic evolution of the New Jersey continental slope and upper rise: an integration of borehole data with seismic reflection profiles: Chapter 30 in Initial reports of the Deep Sea Drilling Project. 1987.

QUARESMA, V.S.; DIAS, G.T. M.; BAPTISTA NETO, J.A. Caracterização da ocorrência de padrões de sonar de varredura lateral e sísmica de alta freqüência $(3,5$ e $7,0 \mathrm{kHz}) \mathrm{na}$ porção sul da Baía de Guanabara. Brazilian Journal of Geophysics, v. I8, n. 2, p. 20।-2।3, 2000. 
QUARTAU, R. et al. Morphology of the Faial Island shelf (Azores): The interplay between volcanic, erosional, depositional, tectonic and mass-wasting processes. Geochemistry, Geophysics, Geosystems, v. 13, n. 4, 2012.

RAD, U.; TAHIR, M. Late Quaternary sedimentation on the outer Indus shelf and slope (Pakistan): evidence from high-resolution seismic data and coring. Marine Geology, v. I38, n. 3, p. 193-236, 1997.

REDDY, D. R.; RAO, T. Sreenivasa. Echo characters of the continental margin, western Bay of Bengal, India. Marine Geology, v. I40, n. I, p. 20I-217, 1997.

ROTHERY, D.; WRIGHT, J. The Ocean Basins: their structure and evolution. 1998.

SCHNEIDER, E.D. et al. Further evidence of contour currents in the western North Atlantic. Earth and Planetary Science Letters, v. 2, n. 4, p. 35I-359, 1967.

SOUZA, L.A.P. Revisão crítica da aplicabilidade dos métodos geofísicos na investigação de áreas submersas rasas. Tese de Doutorado, Universidade de São Paulo, São Paulo, 2006.

SOUZA, R.B.; ROBINSON, I.S. Lagrangian and satellite observations of the Brazilian Coastal Current. Continental Shelf Research, v. 24, n. 2, p. 24I-262, 2004.

SPERA, A. M.. Avaliação das condições paleoclimáticas e paleoceanográficas dos últimos I500 anos na Plataforma Continental de São Sebastião (Sudeste do Brasil) através do uso de proxies geoquímicos. Tese de Doutorado. Universidade de São Paulo, 2016.

SUGUIO, K.; MARTIN, L. Formaçoes quaternarias marinhas do litoral paulista e sul fluminense $=$ quaternary marine formations of the state of Sao Paulo and Southern Rio de Janeiro. 1978.

TEIXEIRA, W. et al. Decifrando a terra. Oficina Textos, $200 \mathrm{I}$.

VAN DEN BERGH, G.D. et al. Acoustical facies analysis at the Ba Lat delta front (Red River Delta, North Vietnam). Journal of Asian Earth Sciences, v. 29, n. 4, p. 532-544, 2007.

VERONEZ JÚNIOR, P. et al. Sonar de varredura lateral e sísmica de alta resolução aplicados no estudo de ecofácies na baía de Vitória-ES. Revista Brasileira de Geofísica, v. 27, n. 3, p. 4II-425, 2009.

VIEIRA, I. et al. A non-deltaic clinoform wedge fed by multiple sources off São Sebastião Island, southeastern Brazilian Shelf. Geo-Marine Letters, v. 38, n. I, p. 63-8I, 2018. 
WAGLE, B. G. et al. Holocene submarine terraces on the western continental shelf of India; implications for sea-level changes. Marine Geology, v. II7, n. I-4, p. 207-225, 1994.

WRIGHT, L. D.; NITTROUER, C. A. Dispersal of river sediments in coastal seas: six contrasting cases. Estuaries, v. 18, n. 3, p. 494-508, 1995.

YOKOYAMA, Y. et al. Timing of the Last Glacial Maximum from observed sea-level minima. Nature, v. 406, n. 6797, p. 7I3-7/6, 2000. 